\title{
2 The genealogical method
}

Introductory remarks by the chapter editor, Odd Einar Haugen

The genealogical method was developed during the nineteenth century, and by the second part of this century it had become a mature and broadly accepted method for the analysis of handwritten texts, primarily from the pre-Gutenberg era, although it had also been applied to printed texts. The genealogical method has often been associated with the German scholar Karl Lachmann (1873-1851), who was active in all major fields of editing - spanning works as diverse as the Nibelungenlied, Lucretius' De rerum natura, and the Greek New Testament. The title of the indispensable study by Sebastiano Timpanaro, La genesi del metodo del Lachmann (1961, rev. ed. 1981, repr. 2004, trans. Most 2005), leaves readers in no doubt about the founding father. However, while the contribution of Lachmann represents a turning point in editorial philology, the genealogical method was not fully developed during his lifetime. The emblematic stemma, part of almost any genealogical recensio, was developed from around 1830, but Lachmann never made one himself. As pointed out in section 2.3 below, it was rather Gaston Paris (with Léopold Pannier) who implemented the basic tenets of what we - in general terms - refer to as the genealogical method; they did this in an edition of the Old French Alexis legend, published at a time when France and Germany were not on particularly friendly terms (Paris and Pannier 1872). It is with this edition that the use of common errors as the major criterion for establishing the text was fully explored for the first time, as Michael D. Reeve reminds us $(1998,464)$, and it is from this time that we can fully describe the genealogical method as the method of shared errors, the Methode der Fehlergemeinschaften. The Alexis edition offers two fully developed stemmata, one drawn by Paris of the earliest version of the legend and one by Pannier of the latest version (Paris and Pannier 1872, 27, 344). Stemmata had indeed been drawn before the Alexis edition, such as the first modern-looking schema cognationis in the edition of the older Västgötalagen [Westrogothic Law] by Carl I. Schlyter and Hans S. Collin (1827), reproduced in section 4.1.1 below, or the stemmata of the Danish classical philologist Johan Nicolai Madvig (1804-1886), for instance the one he offered in his emendations to two speeches by Cicero, reproduced in section 6.1 below (Madvig 1833-1834, 1:9). While these tree models aimed at modelling the filiation process, they were not based on any strict genealogical analysis, and may therefore give a misleading impression of the development of the genealogical method. It is only with the 1872 edition of the Alexis legend, which dates back to work being done in the 1860s by Paris and other scholars such as Karl Bartsch, Gustav Gröber, and Paul Meyer, that the stemma actually becomes a model for the recensio of the manuscripts.

The first section of this chapter, 2.1 by Gerd Haverling, opens with the earliest traces of written literature. This is not to say that the filiation of oral literature falls outside the scope of the genealogical method; it is rather a reflection of the fact that the written text is a prerequisite for subsequent studies, millennia later, of a 
manuscript tradition. Considering the variety of literatures discussed in chapter 7 , dealing only with Greek and Latin texts may look like a narrow approach to the discipline. However, textual criticism, at least in its Western manifestation, was developed in these fields. This tradition led to the professionalisation of the field in the nineteenth century, when the stemma became the supreme model. What Haverling shows in her chronological walk-through, starting with Alexandrian philology and ending two millennia later, is how text-critical concepts have grown over time, and that there was indeed a continuous development of the field that prepared the ground for the methodological advances of the nineteenth century.

In section 2.2, Paolo Chiesa offers a concise introduction to the method with a number of practical examples. Unlike the austere treatise by Paul Maas (1st ed. 1927, 4th ed. 1960), which remains an authoritative statement of the basic principles of the genealogical method, Chiesa takes a broader, at times metaphorical, approach to the subject, while he at the same time manages to present the method in a very precise manner. Looking at the length of Maas's treatise and Chiesa's section, one might wonder what all the fuss is about; if a method can be explained as succinctly as here, practising it should be straightforward. However, texts in all their variability can provide editors with seemingly contradictory combinations of readings. A large number of works contain readings which move from one branch to another in what Pasquali termed "horizontal transmission" and others "contamination" (to be treated in 4.4). As Maas famously observed, there is no remedy against contamination - "Gegen die Kontamination ist kein Kraut gewachsen" (Maas 1960, 30). While Chiesa is acutely aware of this problem, he underlines that contamination need not be the be-all and end-all of a recensio "if the genealogical pattern is used, more correctly, as a metaphor for the mechanisms of textual transmission” (2.2.7 below).

The genealogical method had become almost universal for the recensio of manuscripts in the decades following Gaston Paris's edition, but dissonance broke out during the early twentieth century. While many editors turned towards other editorial models (see 6.1 below) without excessive concern, Joseph Bédier became the leading opponent of Lachmann's method, or to be more precise, of the practice of his own mentor and predecessor, Gaston Paris. As described in section 2.3, by Giovanni Palumbo, Bédier had for a long time struggled with the complexities of the stemma, and, after having edited the vernacular text Lai de l'ombre in the footsteps of Paris (1st ed. 1890, 2nd ed. 1913), he threw in the towel in a groundbreaking article, "La Tradition manuscrite du Lai de l'Ombre” (Bédier 1928). He had come to the conclusion that too many stemmata seemed to be equally possible in a single tradition, even in a small one like that of the Lai de l'ombre, and that the stemmata published were almost always bipartite, that is, had two branches at the top level. This is the starting point for the discussion in section 2.3, which draws up a dichotomy between the criticisms levelled by Bédier and his contemporary Henri Quentin. While Bédier's and Quentin's contributions have been well covered in the historiography of textual criticism, Palumbo instructively uses their opposing strategies as a mirror 
for the critical debate up to the present time. Whereas some have seen the "New" (later often called "Material") Philology from around 1990 as a paradigm shift in editorial philology, to use the terminology of Thomas S. Kuhn (1962), Palumbo instead regards the New Philology in the light of the Bédier-Quentin schism, and as such as being less new than the name would indicate. In his view, the genealogical method is not without challenges, but it remains the most promising of those methods which so far have been tried - or, in a Churchillian understatement, "the worst method except all those others that have been tried" (Vàrvaro 2012, 87).

The New Philology saw itself as a break from the "old philology", moving the focus from the work and its witnesses to the document and its setting. Neo-Lachmannism, on the other hand, is not a break with Lachmannism but a continuous development of the genealogical method. This is an understanding that fits well with the philosophy of science of Karl R. Popper - the idea that there can be incremental development in a discipline (e.g. Popper 1965). Section 2.4, by Paolo Trovato, puts this into practice, tracing the development - or refinement - of the genealogical method step by step through the twentieth and early twenty-first centuries. This is not a story of a method in decline, but rather of a method which has been developed and supplied with new perspectives brought in from a number of textual fields, and often from unrelated ones as well. While chapter 2 opens in the tradition of editing classical - Greek and Latin - texts, section 2.4 demonstrates how the genealogical method has grown over the last two centuries and acquired a much wider potential.

\subsection{Background and early developments}

Gerd V. M. Haverling

"Philology" is originally a Greek word meaning "love of words", and textual criticism and editorial principles in the West in the Middle Ages and in the early modern age descend from Graeco-Roman Antiquity. The copying of a text tends to create mistakes: words are left out or written twice instead of once, synonyms replace the words actually used in the original text, and there may be changes in word order. This was known at a rather early stage in the history of Greek literature and philology. The people who assembled the great library at Alexandria preferred the original manuscripts they had borrowed from the cities (e.g. Athens or Sparta) that owned them, and returned new copies to those cities rather than the originals, which remained in Alexandria (see 2.1.2). A result of this insight was the birth of textual criticism and of editorial technique in the third and second centuries BC.

While the genealogical, stemmatological method was not developed as such until the early nineteenth century, the notions underlying that method gradually developed over more than two millennia. This development will be described in this section. 


\subsubsection{On writing, books, and editing in Antiquity and in the Middle Ages}

In the earliest phases of alphabetic writing, there were only capital letters, which acquired their refined and elegant forms in inscriptions from the classical periods in Greece (fourth century BC) and Rome (first century BC). However, writing on different materials led to the development of various kinds of letters, and cursive writing systems were used for private purposes (figs 2.1-1-2.1-2). These systems influenced the letters used in books, which before late Antiquity always followed a ma jus cule system: in the second century AD, a new form of such a script, the uncial script, was introduced in both the Greek East and the Latin West (fig. 2.2-3). This form of script was used in books in the early Middle Ages as well. However, in late Antiquity and in the Middle Ages, new minuscule scripts evolved. In the West, we find such scripts developing from the last centuries of Antiquity to the eighth and ninth centuries; the most famous and influential of these scripts was the Carolingian minuscule of Charlemagne's empire (fig. 2.2-4). In the East, a new Greek minuscule script was introduced in the production of books in the ninth century. In the West, the Carolingian minuscule was gradually replaced by the so-called Gothic script, beginning in the latter part of the twelfth century. In the late Middle Ages, the Italian Renaissance humanists preferred the Carolingian minuscule, which consequently served as the basis for the creation of the printed Latin alphabet in the

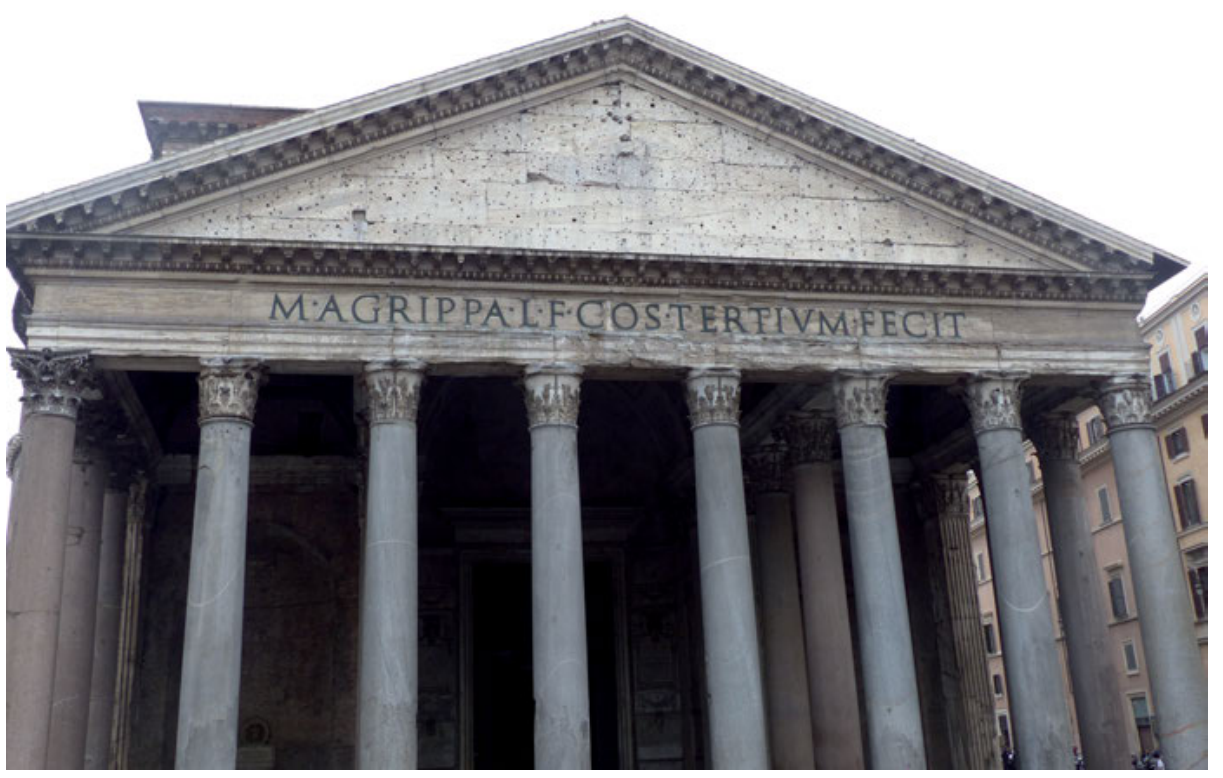

Fig. 2.1-1: Classical capital script on the Pantheon in Rome (27 BC): “M. Agrippa L. f. cos. tertium fecit" = "Marcus Agrippa Lucii filius consul tertium fecit" [Marcus Agrippa, son of Lucius, made this when he was consul for the third time]. Photograph: Philipp Roelli. 


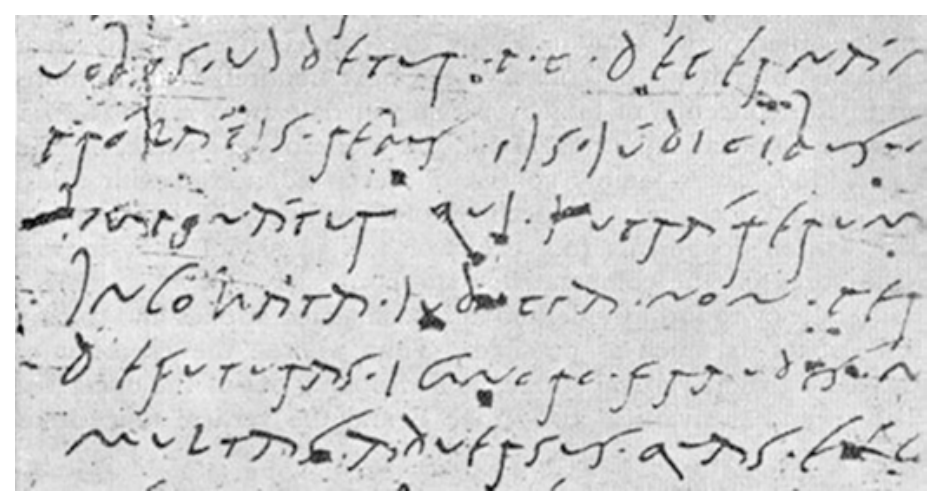

Fig. 2.1-2: Old Roman cursive, from a papyrus fragment in Berlin containing portions of speeches delivered in the Senate, ascribed to the reign of Claudius (r. AD 41-54). Source:commons.wikimedia.org/wiki/File:I_littera_in_manuscripto.jpg.

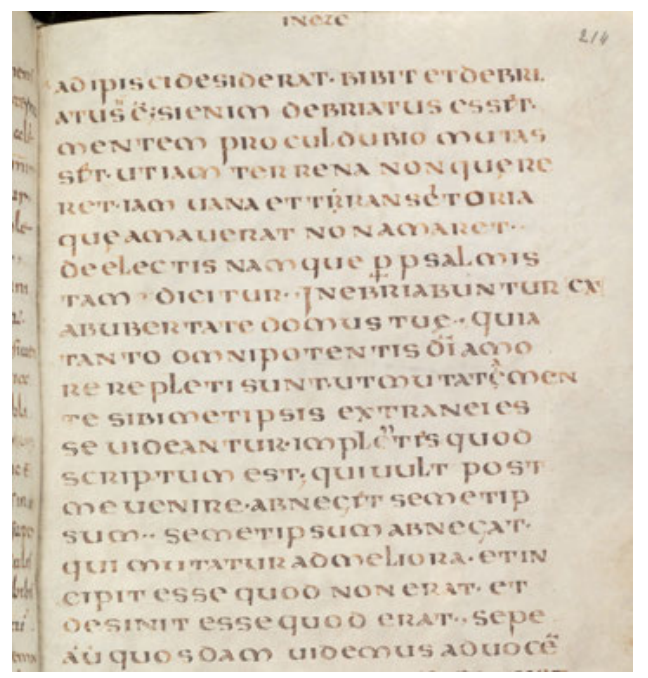

Fig. 2.1-3: Latin uncial from Einsiedeln, Stiftsbibliothek, Codex 157(372), p. 214. Source: e-codices.unifr.ch/en/sbe/0157/214. Image: CC-BY-NC.

\section{C umetrezderponfaza mazereaur mara 10 feph. arrequam conuenireneinuena é. inuzerohaben}

Fig. 2.1-4: Carolingian minuscule, Tours, ca. 850 (Paris, Bibliothèque nationale de France, MS. Lat. 266, f. 24v). Source: Gallica, Bibliothèque nationale de France, gallica.bnf.fr/ark:/12148/ btv1b8451637v/f58.image. Image: CC-BY-NC. 
fifteenth century (see e.g. Bischoff 2009, 76-201; Gastgeber 2003, 4-18; Reynolds and Wilson 2013, 59-61, 89-91, 95-96).

When a text written in one kind of script was rewritten in another script, e r r o r s were sometimes made by the scribes, who may have had difficulties reading the earlier script (on such errors of transliteration, see 4.3 and 1.2.3). This happened both in Antiquity and in the Middle Ages. Such mistakes were often also facilitated by the various abbreviations which were frequently used (this was, however, not so frequent in Greek uncial manuscripts; see also 1.5.2).

A particular difficulty consisted in what is known as scriptio continua, "continuous writing", in which there are no spaces or other marks to separate words and sentences. This was the practice in books until the end of Antiquity and sometimes even after that. In inscriptions, dividers are commonly found, often in the form of dots, but in books this was usually not the case (see e.g. West 1973, 25-28; see also Gastgeber 2003, 43-46). Scriptio continua seems to be a natural way of writing: there are examples from other languages, too. We often find it, for instance, in runic inscriptions in Nordic up to at least AD 1200, sometimes completely, sometimes in part, sometimes with dividers, sometimes not. It is, however, not attested in early Nordic manuscripts in the vernacular, where the earliest fragments are dated to around 1150 (see Haugen 2018a, 223-225).

Texts were copied by professional scribes working in the libraries or for booksellers, but sometimes also by private individuals who needed them for their own purposes. The copying could occur by dictation (i.e. somebody reading the text aloud to several scribes) or by visual inspection (i.e. the copyist had an original in front of him when writing down his new copy of the text). In the Middle Ages, the scribes often worked in scriptoria connected to the monasteries, but, as in Antiquity, the copyist was sometimes a person who wanted the text for his own purposes, for instance a professional who needed a technical handbook for his own work. In this later period, the professional scribes did not always understand the texts that they were copying very well. This is, however, more likely to have been the case if the copyist was copying for his own purposes, for instance a physician copying a medical treatise: such a person is more likely to introduce a synonym instead of the word used in the exemplar than a copyist who has a limited interest in and/or understanding of the text (see e.g. Pöhlmann 1994, 27-40, 47-52; Gastgeber 2003, 18-21; Klopsch 2003, 67-69, 91-92; Salles 2010, 170; see also Bayet 1961, lxxxvi).

A practice connected to the mediaeval universities is the pecia system. It was developed in the early thirteenth century at the Italian universities and spread from there to other universities. A manuscript was broken up into often rather short sections which were called peciae, "pieces”: the size of such a section was often four folios. Students would rent them, section by section, in order to create their own copies of the text. In some cases, there may have been more than one approved exemplar divided into peciae, and in such cases contamination and exemplar shift may have occurred (see e.g. Siri 2013; 4.4 below). 
Texts were published and handled in very diverse ways. Sometimes, there was an original version of a literary text which was relatively stable, but in other cases the picture was more complicated. We know that several classical Greek and Latin texts were revised after publication by their authors or were circulated before the text had been fully revised. In such cases, the various stages of elaboration may be represented by varying readings in the later transmission of the text. A famous example from the classical period is Ovid's work Amores, which, according to the first two lines of the prefatory epigram, was published twice by the poet himself, first in five volumes and then later in three; both editions seem to have been in circulation for some time (see e.g. Pasquali 1934, 18-19; 397-465; see also Booth 1991, 2-3). A mediaeval example of the same phenomenon seems to be the letter collection by the late-twelfth-century author Peter of Blois, which has come down to us in a great amount of manuscripts and in a rather bewildering state (see Wahlgren 1993).

In other cases, texts were altered in a later phase and new versions were created: this happened to many texts of a more technical nature, for example grammatical treatises or texts on medicine. In such cases, we sometimes find changes in the technical terminology or shorter as well as longer versions of the texts. In certain cases, literary texts too were changed in this way: a famous example is the Alexander Romance, of which we have several different versions. A particular kind of new version of a text is the epitome, which is a shortened version of an often much longer text (see e.g. West 1973, 16-18; Reynolds and Wilson 2013, 33-34, 235-238; see also Pasquali 1934, 118-121; Erbse 1961, 234-237; Büchner 1961, 344).

Sometimes, new editions were made because of a change in ideology or perspective. This happened to certain pagan texts which occur in both a "pagan" and a "Christian" edition: a famous example is the stoic philosopher Epictetus' Enchiridion from around AD 100 (see e.g. Gastgeber 2003, 25-26). The copyist may also unconsciously introduce mistakes facilitated by the intellectual or ideological context in which he is living. There are, for instance, some mistakes in the manuscripts of non-Christian texts which betray the influence of Christian thought, as when we read "Sathana" instead of "Athana" in a manuscript of Petronius' novel Satyricon from the first century AD (Satyricon 58.7; see West 1973, 18). An ideological change also affected the historiographical work of the sixth-century Gallo-Roman bishop and aristocrat Gregory of Tours, which was abbreviated and renamed the Historia Francorum [History of the Franks] a couple of generations after the author's death. The version of the text left behind by the author when he died in 594 consisted of ten books, and his own name for it was Decem libri historiarum [Ten Books on History]: it is a work on the history of the world from a Christian perspective, putting contemporary events in Gaul into the perspective of God's plan for the human race. The new, shorter version consists of a selection from the first six books, in which sections of less interest from the point of view of the history of the Franks have been left out. This new version is connected to later works on Merovingian history such as the Chronicles by someone who is conventionally called Fredegar (seventh 
century) and to the Liber historiae Francorum [Book on the History of the Franks] (eighth century), and reflects a change in perspective in a world in which the GalloRoman elite had merged with the Frankish one and a new common identity had been born (see Heinzelmann 2001, 94-115, 192-201; see also Haverling 2008).

Sometimes, an edition was made from a text which was not intended for publication in that form by the author. Some of Aristotle's transmitted works from the fourth century BC go back to lecture notes which seem to have been made by the author himself (see e.g. Howatson 1989, 57; Lesky 1996, 552-553; Erbse 1961, 230231). The teachings of several mediaeval philosophers are known to us from such notes made by their students. In a mediaeval university lecture, the teacher read a text aloud to the students (cf. expressions like lectio, lecture, and Vorlesung): in the beginning, the intention was that they should learn the text by heart. However, when the matters taught gradually became more complex, it was clear that it was necessary to take notes during lectures. As a result, the reportatio arose - a collection of notes which the student could bring home and study. Sometimes, such annotations spread among the students and were copied among them (see e.g. Siri 2013). A famous modern example of a publication made on the basis of lecture notes made by others is Ferdinand de Saussure's Cours de linguistique générale. This fundamental work was published in 1916 (three years after the author's death) on the basis of annotations made by his students during lectures which he held between 1907 and 1911 (critical edition: de Saussure 1972).

A particular kind of edition is the anthology (anthologia or, in Latin, florilegium). In contrast to the epitome, which is a shortened version of a longer text, the anthology typically contains texts written by several different authors or a selection of texts written by the same author. In Antiquity, important anthologies containing the works of several different poets were thus created (reflected, for instance, by the Anthologia Graeca with Greek poems and the Codex Salmasianus, today Paris, Bibliothèque nationale de France, Lat. 10318, containing minor Latin poets). There were also anthologies produced for school purposes (see e.g. Lesky 1996, 741-743; Conte 1994, 609, 610-611; Erbse 1961, 227-230, 246). Anthologies remained important in the Middle Ages and were then made up of texts by both ancient and mediaeval authors: there were anthologies produced for school purposes but also anthologies of elegant letters, which were to serve as models for those writing letters. Many mediaeval manuscripts contain collections of extracts from different authors and can therefore be regarded as a kind of anthologies (see e.g. Pöhlmann 1994, 95; Reynolds and Wilson 2013, 108, 114, 118; for a concrete example, see Nyström 2009).

\subsubsection{On philology and textual criticism in Antiquity and in the Middle ages}

Since various kinds of unintentional changes can be introduced when a text is copied (for example, something can be misinterpreted or left out, or mistakes can be 
induced by phonetic and orthographical changes; see, in more detail, 4.3), it soon became clear that no handwritten copy was entirely reliable. When the great library in Alexandria was founded in the early third century BC, as mentioned above, it was clear to those who acquired the books that the original was better than the copy, and therefore they did not hesitate to steal originals from the Greek cities that possessed them, replacing them only with new copies. It was in this environment that the philological practice of comparing several manuscripts in order to reconstruct a text was born. Important editions of pre-classical Greek poets, first Homer and then others, were created there (see e.g. Pöhlmann 1994, 26-40; Reynolds and Wilson 2013, 5-16).

The Alexandrian philologists were often able to take into consideration a rather large number of different manuscripts: this was the case when Aristarchus of Samothrace worked on Homer in Alexandria in the second century BC. It is, however, not likely that Aristarchus used all that material for a systematic study of the internal relationships between the manuscripts in a modern sense: he seems rather to have compared a version of the text which he considered particularly reliable to other versions, and thus produced a text which was free from obvious faults and which then replaced the multitude of earlier versions - this new version of the text was then copied and reproduced and the earlier versions were not. Various signs to facilitate reading, such as the Greek accents invented at this time for this purpose, as well as others to draw attention to suspicious or problematic readings, were introduced (fig. 2.1-5). The Alexandrian practices of comparing manuscripts in order to produce a canonical version of a text, of drawing attention to problems in the text with the help of a number of signs, and of making editions of older texts were introduced to Rome in the second and first centuries BC (see e.g. Pöhlmann 1994, 26-40, 46-49, 61; Reynolds and Wilson 2013, 7-16, 21-22).

Discussion of difficult passages led to the production of more reliable texts, but also to commentaries in which such problems were discussed. The writing of such commentaries was introduced to Rome in the second and first centuries AD as well. These commentaries were initially separate texts, but they were later turned into s cholia, which are a kind of commentary written around the text that is being studied. Some such scholia on papyrus scrolls from the Hellenistic period are extant, but they seem to have become more common in late Antiquity and in the Middle Ages, when parchment codices had replaced the papyrus scrolls of previous centuries. Sometimes, such scholia were later spelled out as commentaries again. Some commentaries on older texts are preserved (mostly from late Antiquity), and we have knowledge of numerous other such texts from quotations in later works on grammar and lexicography and from later commentaries on important literary works (see e.g. Pöhlmann 1994, 77, 79, 82; Reynolds and Wilson 2013, 10-11, 45, 5253, 77; on scholia and commentaries, see also Dickey 2007; Zetzel 2018).

In the early Roman Empire, scholars were fully aware of several reasons why texts may become corrupt in the course of transmission. They discussed what kind 


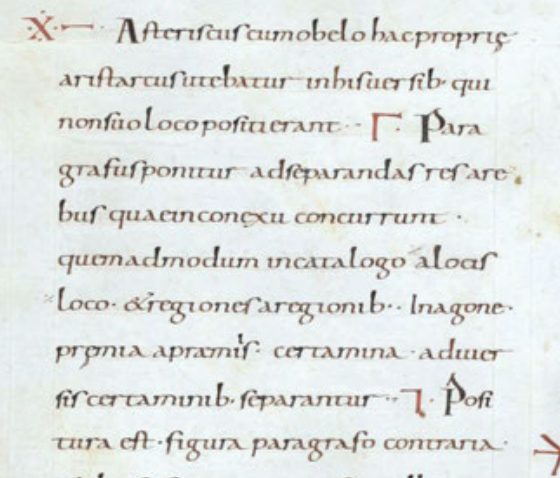
Ladeoficformaca qua fiat ille pren apta notax t taufa finer aprencapur reparat... (-) Crfix arculeparrenfe ror cumpunciopontuw unbirloar ubrquefto dura cóbfaura aperer ud foluz nonpozur - ' - A nafion ma pontur adeoruer fuf quorum or dopmutandureft ficónamaquif auctorib poftum muentar -

D. A rafumma campuncto pontur unbur loair ubu uneodem fenfü duple cefterfurfunt - sidubuxar qupo uufeligendurfix. $>$ Otple bane forptorer nofte apponume enlebrir edefiafucorum urorum - adiepa randa uel demonftranda uxtumona fancaurum forpurarum. $\zeta_{7}$. Òple perdifticon - hencpremur leogorar fira cafinur pofutz bomerafuer rib adfe parazonem dimpr-acglo.. $\%$ Otple pdeftigmene-Ideft cumgomentpunc ar hanc antuque urhe oppondbart quaczenodour offefur nonrectead

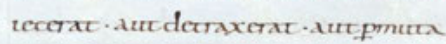
uera enher ároftr en ufi für

Dipleobolefinene unter pontur ad reparandor incomeduf ud tragoeduf prodor:- 3 入uera obolufinene quo tuenf trofo damatrofur infelur.,

F入uerra cumobolo-ader pontur quacadaliqued refptcuun - tunor ne ubifluxar fingrae refuetue fundo. " conamur nof armica of querobafad3 urobrex . 7 . Otple fupne obo Lax pontzur adcondtzoner locoriu actomporum pronarumq mutacas:

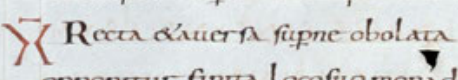
oppontur funta locofuo monade. rignificame fimt lon fequentem quoq: ere. $X$ Cgraunum pontzur quo zenr muluuer fur inprobanair. necpfingulor obolemar 'cerauzum

Fig. 2.1-5: A description of Alexandrian textual-criticism signs (in red) from Isidore of Seville Etymologiae 1.21 (St. Gallen, Stiftsbibliothek, Cod. Sang. 231, p. 36). Source: e-codices.unifr.ch/en/csg/0231/36 Image: CC-BY-NC.

of orthography might have been used in the old texts, and they were aware of the risk of unusual words getting distorted in favour of more common ones. The idea of the lectio difficilior, the more difficult but likely more correct reading, as the choice to be preferred by the editor was established in the first two centuries AD: in the first century, the grammarian Probus proposed such readings for Virgil's Aeneid, and in the second, the Greek physician Galen (129-200/216) considered older but more difficult readings more trustworthy. Therefore, scholars were not only comparing manuscripts when they tried to establish what might be the correct reading; they were also particularly interested in old manuscripts and the information 
they could furnish about the old texts (see e.g. Pöhlmann 1994, 61-78; Reynolds and Wilson 2013, 25-34).

The philological practice of comparing manuscripts (without necessarily trying to arrange them in a stemma) in order to produce a can onical version of a text was used when new editions of classical texts were produced in expensive parchment codices in late Antiquity. Sometimes, these new editions were sponsored by wealthy private persons: a famous example is the new edition of Livy's gigantic work on Roman history from the late first century BC and the early first century AD that was sponsored around $\mathrm{AD} 400$ by two leading senatorial families who were also prominent in the pagan opposition to the Christianisation of the Roman Empire, the Symmachi and the Nicomachi. We are informed about this by certain colophons in the preserved manuscripts. This activity in late Antiquity is of fundamental importance not only for the survival of classical literature but also for the shape in which the classical literary texts have come down to us. In a few cases, late antique parchment codices of this kind have survived: there are some such manuscripts extant of, for instance, Virgil, Terence, and Livy. In many other cases, however, we can trace the preserved tradition back to such a manuscript in late Antiquity which has not survived (see e.g. Pöhlmann 1994, 82-86; Reynolds and Wilson 2013, 3943; for Livy, see Bayet 1961, xvi-c).

These editorial principles were developed for and applied to canonical literary texts such as those of Homer and Virgil. They were not applied to the same extent to texts in which the original wording was considered to be of less importance, for instance to "technical" texts on medicine or grammar. In such cases, the copyists, who might be interested in using the texts for their own purposes, were more inclined to introduce changes intentionally: these changes could be changes in the technical vocabulary, but also involved rendering the text longer or shorter than the original. Certain texts which were to be used in schools were deliberately modified, too (see e.g. Pasquali 1934, 118-121; West 1973, 16-18; Reynolds and Wilson 2013, 235-238; for a concrete example, see Haverling 2003).

After the problematic period at the beginning of the Middle Ages sometimes referred to as the "Dark Ages", scholarly and philological activities were resumed. In the ninth century, texts were transcribed into the new minuscule scripts in both the Greek East and the Latin West. New commentaries on ancient texts were sometimes written, and old commentaries were studied and assembled. The value of different readings was discussed, and scholars compared different manuscripts with one another or suggested con jectures and emendations to improve the readability of the texts. Difficult words were commented on or explained in so-called glosses around the text. Scribes made annotations about such things: sometimes we can observe this in the form of various hands which have added such information in the margins or above the lines in the manuscripts. Sometimes, the mediaeval copyist used, with the intention of getting as accurate a text as possible, more than one manuscript when producing the new manuscript: to the modern scholar trying 
to figure out how the mediaeval manuscripts of a certain text relate to one another, this procedure poses a challenge known as contamination (see 4.4), but it is actually similar to the method used in Antiquity to produce readable texts (see e.g. West 1973, 12-14, 22-23; Reynolds and Wilson 2013, 59-60, 69-71, 78, 83, 99, 103-107; Pasquali 1934, 146-155, 491).

As examples of the use of such principles in the editing of texts during and shortly after the Carolingian Renewal, Theodulf of Orléans (ca. 750/760-821) and Lupus Servatus (ca. 805-ca. 862) may be mentioned. Theodulf of Orléans was a scholar of Visigothic descent who was named bishop of Orléans in 798 and who, in the early ninth century, produced an edition of parts of the Vulgate Bible in which he used sigla in the margin to indicate the sources of his variants. Lupus Servatus was a German who became abbot of Ferrières in France, and who eagerly tried to get hold of other manuscripts of texts which he already knew in order to compare them with the ones he had. He was also interested in points of grammar, prosody, and exegesis. His work is reflected in the manuscripts of several ancient texts which were copied in this period (see e.g. Reynolds and Wilson 2013, 105-106; Klopsch 2003, 79-80; Pasquali 1934, 155n2; see also 1.4.1 above).

This scholarly activity continued during the subsequent centuries, and important manuscripts of ancient texts were produced. Book collections were assembled, for example around the Ottonian court. Of great importance was the revival of the learned monastery of Monte Cassino in the eleventh century. The work to improve the text of the Bible was intensified, and in the twelfth century, the Roman monk Nicola Maniacutia produced a revised version of the psalter. The scholastic age (late twelfth-thirteenth centuries) was more focused on philosophy and science, due to the recent discoveries and translations of texts in those areas, but in the fourteenth century there was again a growing interest in the literary classics of the ancient world (see e.g. Reynolds and Wilson 2013, 107-135, 281; Peri 1967).

\subsubsection{On philology and the editing of texts during the Renaissance}

In the later Middle Ages and in the early Renaissance, literacy and learning had become more common outside the Church, and interest in classical literature grew stronger: as a result, there was a further increase in the search for and in the copying of such texts. There was now more contact with the Greek-speaking world, and Westerners, first Italians and then others, were learning Greek again. There was also an increasing production of new texts, in the classical as well as in the vernacular languages, which were copied and edited (see e.g. Reynolds and Wilson 2013, 123141; Heldmann 2003, 97-102; see also 1.4 above).

It was in Italy that this new Renaissance movement started. One of its most significant traits was a renewed interest in Greek and in Greek literature. Greek was little known in the north of Italy, although it was still spoken in certain areas in the 
south, but in the fourteenth century there was an increasing demand for learning it, and from 1397 there were regular lectures on Greek in Florence. Some Italians travelled to the East to seek instruction in the language as well as to collect manuscripts. After the fall of Constantinople (1453), numerous Greek scholars fled to Italy, which considerably increased the number of available teachers of the language and of professional Greek copyists. The ties between the Greeks and the Italians were further strengthened by Cardinal Bessarion (1403-1472), a Greek orthodox bishop who had become a Roman catholic cardinal and who played a conspicuous role in the cultural life of Rome and Italy, for instance by collecting as many Greek books as he could and then offering them to the city of Venice to form the basis of a public library (see e.g. Reynolds and Wilson 2013, 147-155).

As a result of these changes, the conditions for working on and understanding the classical texts had greatly improved in the fifteenth century in Italy. In the first part of that century, Lorenzo Valla (ca. 1407-1457) made an important Latin translation of the Athenian historian Thucydides (ca. 460-ca. 400 BC), wrote a fundamental treatise on Latin style and grammar based on a close study of the classical texts, and published works on textual problems in the Roman historian Livy as well as in the Greek New Testament (see e.g. Reynolds and Wilson 2013, 141-144; Heldmann 2003, 128).

A generation later, Angelo Ambrogini, better known as Politianus (or, in English, Politian; 1454-1494), employed new and strikingly modern methods of dealing with textual problems. He emended a difficult passage in the Roman poet Catullus (84-54 BC) with the help of the Hellenistic poet Callimachus (ca. 310-240 BC), to whose Coma Berenices [Lock of Berenice] Catullus referred in poem 66: in Callimachus Fragment 35c, we read "X $\alpha \lambda u ́ \beta \omega \nu$ "; but, in the Catullus manuscripts, "Chalybum" or "Chalybon" (line 48), which Politian restored, had been changed to "celitum" (or "celerum"). When discussing the relationship between the manuscripts of Valerius Flaccus, a Roman poet from the first century AD, Politian observed that the later manuscripts were of less value since they were the copies of the older manuscripts, which means that he followed the principle of eliminatio codicum descriptorum (see 6.2). He generally preferred older manuscripts to more recent ones and employed the principle that conjectural emendation must start from the earliest recoverable stage of the tradition. Such ideas were to become common only in the nineteenth century and the age of Karl Lachmann. In his printed copies of classical texts, Politian frequently made annotations to readings found in manuscripts he had seen. Even if he thus paid much attention to the manuscripts, he did not hesitate to suggest conjectures when he found this appropriate; but, in contrast to some of his contemporaries, he honestly informed his readership when he proposed a conjecture and why he did so. He did not, as some of his contemporaries, try to hide himself behind some unspecified "good manuscripts" (see e.g. Heldmann 2003, 120-124; Reynolds and Wilson 2013, 144-147, 154-155).

When Politian was active as a classical scholar, printing technology had just been introduced. The Latin Bible was the first text to be printed, but soon it was 
followed by classical literary texts: by 1475 , the most important Latin classics were already available in printed books, and the number of such texts which were printed was growing. The Greek texts which were available in print were, however, far less numerous. One problem was the designing of a suitable font, but another was the restricted number of potential buyers of Greek books in the West. However, in 1494, Aldus Manutius (ca. 1450-1515) set up a publishing house primarily for the printing of Greek texts. He did this in Venice, where he hoped to get access to the library of Greek texts that Cardinal Bessarion had donated to the city - which, however, he probably did not. Over a period of about twenty years, a great number of ancient Greek texts, especially classical and non-Christian ones, were printed (see Reynolds and Wilson 2013, 145-146, 155-160).

The early editions thus created were often based on only one manuscript (sometimes called monoptic editions; see 6.1), but often there were also attempts to compare different manuscripts with one another and to try to establish a better text in this way. The comparison of the manuscripts was, however, then often rather arbitrary, and it was frequently based on the probability of the various readings in mostly relatively recent manuscripts. A reason for preferring later manuscripts was probably the lack of sufficient palaeographical knowledge to deal with the older ones. Unfortunately, these early editors and printers did not always regard it necessary to keep the manuscripts they had used - nor did they necessarily indicate where they had introduced conjectures and emendations. Important information about the preceding manuscript traditions was therefore often lost (see e.g. Heldmann 2003, 108-112). One example of this is the first edition of Symmachus' Relationes (from AD 384), which was published in Basle in 1549 by Sigismundus Gelenius: this edition was based on a now-lost manuscript and evidently not on a comparison with the two eleventh-century manuscripts of the same text that have survived (see Seeck 1883, xix-xxii). These first prints were therefore often of a relatively poor quality.

The first print of the classical Greek poet Pindar (early fifth century BC) was published by Manutius in 1513. In contrast to the edition which, only two years later, in 1515, was presented in Rome by the Greek scholar Zacharias Kallierges (ca. 1473-after 1524), it was not of great importance. The Kallierges print was based on different manuscript material and also included the scholia; it has been - and still is - of fundamental value to scholars working on this fascinating but very difficult poet. There is, however, a problem connected to this edition: not all the copies of what appears to be the same edition are identical. Some pages at the beginning occur in two forms, each typeset differently: the printer had, in other words, changed the text before the printing of the book was finished. To throw away all the paper already printed was not something that a printer in the early sixteenth century could afford. The book was therefore published in what appears to be one edition but with these variations between the copies (see Fogelmark 2015, 1:3-4, 56-61). 
The Dutch scholar Erasmus of Rotterdam (ca. 1469-1539) was a very famous Renaissance editor. Of particular importance is his edition of the Greek New Testament, which was published in Basle in 1516. This very first printed edition of this text in the original language was based on a few relatively recent manuscripts. Erasmus was aware of the likely value of old manuscripts, but he did not have sufficient palaeographical knowledge to consult them. When there were lacunae in the Greek manuscripts which he used, he consulted the Latin Vulgate translation and made his own Greek versions of them. There are thus some problems in the methods applied when this edition was made, but it was nevertheless of fundamental importance because it finally established the principle that texts should be studied in the original language and not in translation, and that the texts of the Christian Bible are to be dealt with in the same way as other ancient texts. This first edition would then be followed by several reprints and new editions, among them a fourth edition from 1527 for which further and better manuscripts, including the Spanish edition of the Greek Bible from 1522, had been consulted (see e.g. Heldmann 2003, 127-130; Reynolds and Wilson 2013, 160-164; see also 7.1.1.2 below).

Erasmus' edition of the New Testament was very successful, and it was reprinted in the sixteenth and seventeenth centuries. In one of these editions, the text edited by Erasmus is referred to as the textus receptus, "the accepted text", which was not supposed to be altered. Not only this edition but also editions of classical texts were sometimes treated in this way. Later Renaissance editors often chose to improve the first printed edition by conjecture (ope ingenii) or by consulting other manuscripts (ope codicum), without trying to make an entirely new edition based on an independent study of the preserved manuscripts (see e.g. Heldmann 2003, 130-134; Reynolds and Wilson 2013, 188, 210; Tarrant 2016, 65).

A quite different example of editorial approaches in the Renaissance should also be mentioned. It is found in the edition of a medical text, a commentary in Latin on a Latin translation of the Hippocratic Aphorisms, made by Johann Winter, a German scholar from Andernach (1505-1574; the full title of the edition, which was published in Venice in 1533 and in Basle in 1535, is D. Oribasii Medici clarissimi commentaria in Aphorismos Hippocratis hactenus non visa, Ioannis Guinterij Adernaci Doctoris Medici industria, velut e profundissimis tenebris eruta, et nunc primum in Medicinae studiosorum utilitatem edita). The translation commented on was probably made around AD 500, and the Latin in it is in several respects quite substandard, even more so than the Latin of the commentary, which was probably written around 600. Winter therefore chose to use a more elegant translation from around 1100 , which is not combined with this commentary in the manuscripts, and he combined it with a relatively recent and polished version of the commentary which appears in some manuscripts from the eleventh century onwards (see Vázquez Buján 2010; see also Haverling 2003, 2019). In this case, the purpose was not to publish an admired classical text but to render an important medical text accessible to the physicians of the day. 
The principles applied by the editors during the first century of the new printing technology often differed quite strongly from modern attitudes on such matters. However, at the same time, there was some awareness of the importance of older manuscripts and of the fact that the more difficult reading would often be the correct one. We also sometimes encounter the idea that the preserved manuscripts of a certain text probably descended from a common origin - what we now would refer to as an archetype - but the term archetypus was used in the Renaissance in a different sense, to refer to what we now call an autograph. This is confusing, since the modern use of the term is quite different (see Irigoin 1977; 4.1.2 below). Furthermore, there was also a growing awareness of the importance of taking the linguistic and stylistic habits of the author, as well as contextual information about, for instance, history or a Greek model, into account when choosing between variants in the manuscripts (see e.g. Heldmann 2003, 108-130). That there was a growing awareness of such things is shown by the fact that the first known treatises on textual criticism were the De arte, sive ratione corrigendi antiquorum libros disputatio and the Thesaurus criticus, first published in 1548 and in 1557 respectively, by the Italian scholar and skilled editor of Greek texts Francesco Robortello (1516-1567; see also Reynolds and Wilson 2013, 168). These same ideas, which can already be observed among some textual critics in Antiquity, will gain more importance in the following centuries.

\subsubsection{On philology and the editing of texts from the late sixteenth to the end of the eighteenth century}

The cultural climate changed drastically during the Reformation. In the Catholic countries in the south, there was now less tolerance for the critical spirit of the Renaissance and the Latin Vulgate translation of the Bible was again regarded as the correct version to adhere to (see e.g. Reynolds and Wilson 2013, 165-171). From the latter part of the sixteenth century, there is, however, increasing activity in the editing of classical texts north of the Alps. The Dutch scholar Justus Lipsius (15471606) made important contributions to the editing of several classical Latin texts, especially by the Roman historian Tacitus (ca. AD 100) and the Roman philosopher Seneca (first century AD). His contemporary, the very learned French scholar Joseph Justus Scaliger (1540-1609), reconstructed the chronological system of the ancient world and attempted to reconstruct the details of a lost archetype in his edition of the classical Roman poet Catullus (84-54 BC). Scaliger's younger friend Isaac Casaubon (1559-1614), born in Geneva as the son of French Huguenots, dedicated his vast erudition and energy to illuminating difficult but often widespread texts, and he commented on authors such as the Greek Diogenes Laertius, Strabo, and Athenaeus, but also on Roman poets such as Persius. There was now a stronger interest in the evidence of the manuscript traditions, and in an edition of Horace (65-8 BC) 
by Theodoor Poelman (1510-1607), s igla were for the first time used in a modern manner to denote the manuscripts. In an edition of Seneca's tragedies, Johann Friedrich Gronovius (1611-1671) used a manuscript which had been neglected since the Renaissance but whose importance was now firmly established. A general problem in philology much discussed at this time is the balance between emendation by conjecture (ope ingenii) and with the help of a close study of the manuscripts (ope codicum): Nicolaus Heinsius (1620-1681) managed to strike a reasonable balance in his editions of several Roman poets (see e.g. Reynolds and Wilson 2013, 171-185).

Scholars had known for centuries that older manuscripts can be of particular value for the editing of a text. Old manuscripts are, however, often written in old scripts which are not always easy to read, and sometimes the manuscripts themselves are badly preserved. Each change of script in Antiquity and in the Middle Ages therefore posed a problem. An important step towards the development of modern philology was the establishment of the study of manuscripts and of palaeography in the late seventeenth century (see e.g. Reynolds and Wilson 2013, 193197; 1.5 above).

The idea that the first printed version - especially of the Greek New Testament, but of other ancient texts as well - had a particular status as the textus receptus prevailed for a long time. For a growing number of classical literary texts, this was gradually undermined by scholars who proved the importance of other textual witnesses than the ones used for the first printed versions of the texts and who proposed conjectures and emendations for those texts. Holy Scripture was, however, another matter. The Englishman Richard Bentley (1662-1742) had already contributed to the understanding of numerous classical texts with often brilliant conjectures when he started work on the manuscript tradition of the Greek New Testament in 1716 with the intention of publishing a new edition of the text; in this work, he broke with the tradition that treated Erasmus' version of the text as the textus receptus. Bentley never finished work on this edition, but he published a tiny pamphlet in which he announced that he would base his edition on the oldest textual witnesses and on the fourth-century Latin translation, the Versio vulgata. Similar views about what an edition of this text should be like were now proposed by others as well, and new editions following such principles were published. In 1734, the German theologian Johann Albrecht Bengel (1687-1752) published an edition of the Greek New Testament in which he discussed the internal relationship between the manuscripts. This methodological approach was soon adopted among scholars working on the classical texts in the latter part of the eighteenth century (see e.g. Heldmann 2003, 134135; Pöhlmann 2003, 137-139; Reynolds and Wilson 2013, 185-190).

A new method based on a close study of the internal relationships between the manuscripts and the attempt to, if possible, establish an archetype was thus developing in the eighteenth century. This is the method later associated with the name of the nineteenth-century German scholar Karl Lachmann, which will be discussed in the following section. 


\subsection{Principles and practice}

Paolo Chiesa

The genealogical method - also called, not quite appropriately, "Lachmann's meth od" (see 2.3) - played a pivotal role in developing a scientific approach to textual criticism, and it still remains an essential research tool. This section provides a short rationale of the method in its logical principles and practical application; its strengths and weaknesses are briefly discussed through examples, both real and invented.

\subsubsection{A definition}

The genealogical method meets the need, clearly felt at the historical moment in which it was developed, to limit the subjectivity (iudicium) of the critical editor in choosing between the reading s (i.e. "what is read", the variants of the manuscripts) occurring in the tradition of a literary work. It attempts to replace, as far as possible, subjective criteria with objective ones. It advertises itself as a "scientific" method based on a set of predefined and encoded rules. The cultural climate in which the method developed was the eighteenth-century Enlightenment and nineteenth-century positivism; the "enemy" to overcome were the editions produced since the second half of the fifteenth century, which had generated a number of textus recepti (see 2.1.3) without philological value.

The genealogical method is also called "Lachmann's method", from the name of Karl Lachmann (1793-1851), a German classical scholar who was considered to be its creator or architect. In fact, this method was constructed over a rather long timespan (from the last decades of the eighteenth century to the early twentieth century) thanks to the contributions of many scholars, sometimes working in connection with one another, sometimes working autonomously. The predominance of Lachmann's name mainly arises from his famous edition of Lucretius' poem De rerum natura, in which he provided a spectacular reconstruction of the supposed earliest manuscript of the work, applying some principles of the method (the Lucretius transmission was discussed in 1.4.2). This demonstration and the long-standing fame of the scholar, kept alive by the academic circles of Berlin, produced an identification (largely undue) between his name and the method (see Timpanaro 1981, repr. 2004, trans. Most 2005; Fiesoli 2000, 359-461).

In the tradition of textual studies, the most consistent treatment of the genealogical method is considered to be that provided by the German scholar Paul Maas (1880-1964) in his Textkritik (Maas 1957, trans. Flower 1958); for a canonical description in English, see West (1973). 


\subsubsection{The genealogical metaphor}

At the basis of the genealogical method lies the insight that a proper analysis of the tradition of a work is a powerful and indispensable tool for reconstructing the text. The tradition of a work consists of all the facts and objects that have transmitted the work through time, from its origin to us: primarily the preserved manuscripts, or even the lost manuscripts we are aware of (and secondarily the indirect tradition, i.e. quotations, extracts, paraphrases, imitations, and so on, which we do not discuss here; see instead 3.2). These objects are designated as witnesses of the work, using a judicial metaphor. In order to represent the tradition in its historical development, we can use another metaphor, representing every witness of the text as a member of a lineage. A lineage derives from a historical parent and materialises in individuals, children, grandchildren, and descendants, who in turn generate other children, grandchildren, and descendants. Similarly, the tradition of a literary work starts from a parent (the ori g in al, the text as conceived by the author) and proceeds through subsequent generations of handwritten copies that are produced by taking earlier manuscripts as models. As the development of a lineage is represented by a family tree, so too the tradition of a literary work can be represented by a similar diagram, a "family tree of manuscripts" (in Latin, st em ma co di cum), explaining historical relationships among witnesses; and the terminology of family relationships may be useful for representing relationships between manuscripts as well. Scholars say, for example, that a manuscript "descends" from another; that a manuscript is "ancestor", or "progenitor", or "sibling" of another; that two manuscripts are "twins"; that some manuscripts constitute a "family"; and so on. For a more theoretical view of the stemma codicum, see section 4.1.

\subsubsection{Basic principles}

The principles of the genealogical method are summarised as follows.

(i) The value of a reading depends on the value of the witness that reports it. The value of a single witness is measured in terms of its relationships of dependence or autonomy with the other witnesses.

(ii) Only when the relationships between the witnesses have been determined, can the text be reconstructed.

Thus, textual criticism based on the genealogical method clearly separates two phases of research which should be executed in succession: (i) reconstruction of the relationships between the witnesses (a step called recensio), and (ii) reconstruction of the text (a step called constitutio textus; see further 6.2).

\subsubsection{What a stemma codicum is for}

In order to illustrate how the genealogical method works, we start with a practical example. It is an (invented) case of an ancient or mediaeval work; no original manu- 


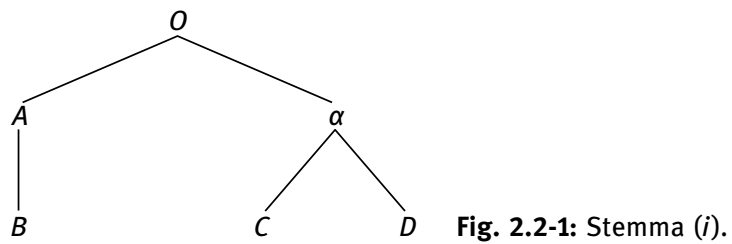

script survives, but we have four later copies (witnesses $A B C D$ ). The relationships between the four witnesses could take many different shapes; at the beginning of the investigation, we do not know the correct one. For example, the witnesses might be related as shown in figure 2.2-1.

This is a stemma codicum, that is, a graphical representation of the relationships between the witnesses. In this stemma, we conventionally indicate the lost original with $O$, the surviving witnesses with Roman letters, and the lost witnesses whose existence has apparently been confirmed by research with Greek letters. In this stemma, the original, $O$, generated two copies, one still existent $(A)$ and one lost $(\alpha)$; $A$ generated another copy, still surviving $(B) ; \alpha$ generated two other copies, still surviving as well $(C$ and $D)$. Every stemma indicates derivation (in our case, of $B$ from $A$ ), closeness (of $C$ and $D$, descending from the same lost witness), and independence (e.g. of $A$ from $\alpha$ ). Every stemma is a diachronic schema, representing a historical sequence from the oldest object (the original, the starting point, the "parent") to the latest outcomes.

If scholars know that the relations between the witnesses are those outlined above, their work in reconstructing the original text becomes considerably easier and, above all, firmer. Since the goal is to rebuild $O, B$ is useless as a witness, because it derives from $A$ : we should consider every reading reported by $B$ but not shared by $A$ as an innovation produced in the transition from $A$ to $B$; such a reading is therefore "false" in terms of the goal of reconstructing the original. However, even a reading reported by $C$ alone against the pair $A D$ can be supposed to be "false": it was obviously generated in the transition from $\alpha$ to $C$, while the reading of $\alpha$ was the same of $A$, as demonstrated by its presence in $D$. The same holds for the readings reported by $D$ alone. In this way, using the stemma, many variants found in the tradition are "automatically" or "mechanically" discarded: those reported by $D$ alone, those reported by $C$ alone, and all those reported by $B$ (this witness may be excluded a priori from further consideration). When the reading of $A$ coincides with the reading of $\alpha$, it corresponds to the reading of the original, $O$. The only cases in which doubts still persist, and in which editors have to make a choice, are when the reading of $A$ is opposed to the reading of $\alpha$, that is, the common reading of $C D$ - presumably, a small part of the total variants in the tradition; since the task was to reduce the editor's subjective choice, we gain a major advantage.

The relationship between the four witnesses, and their stemma, might be different, of course. Figure 2.2-2 offers another possibility. 


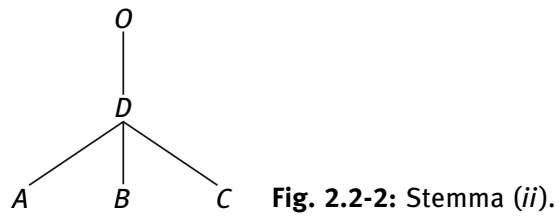

In this case, the reconstruction of the original, $O$, can proceed on the basis of a single witness $(D)$, for the other three derive from the latter. This means a strong simplification in the work of any critical editor, and a stronger degree of certainty. Such certainty lies in the power to securely label as "false" each and every individual reading of the three manuscripts $A B C$ (an operation scholars call eliminatio lectionum singularium). Actually, the single readings of $D$ are not all necessarily "true" (i.e. corresponding to the original): in the transition from $O$ to $D$, innovations may have been produced, which the editor needs to identify and eliminate. Nevertheless, the value of $D$ as a witness is undoubtedly greater than the value of any of the other manuscripts.

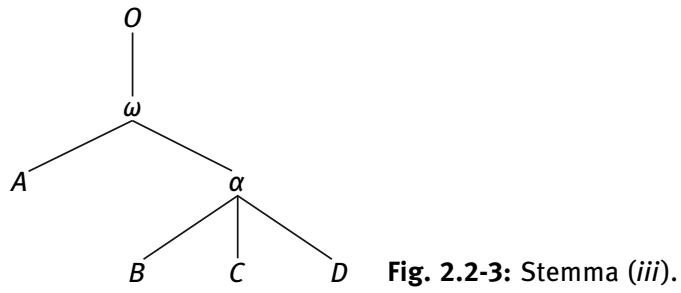

In this case (fig. 2.2-3), the tradition departs from a lost manuscript, $\omega$, which contains some innovations compared to the original; in philological terms, such a manuscript is called an archety pe (see 4.1.5). As a first step, the critical editor must recover the readings of $\omega$. That can be done with certainty when $A$ and $\alpha$ coincide, but requires a choice when they diverge. Once the readings of $\omega$ have been reconstructed, there is no guarantee that these readings correspond to the original, $O$ : as with manuscript $D$ in the previous case, some innovations might have been produced in the transition from $O$ to $\omega$, and they have to be detected and eliminated.

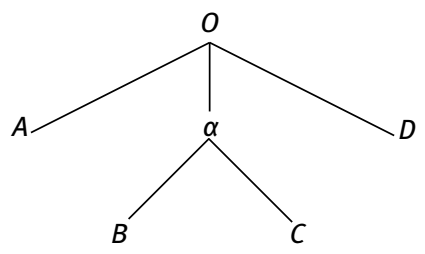

Fig. 2.2-4: Stemma (iv). 
In this case (fig. 2.2-4), the tradition splits into three branches. Three witnesses, each independent of one another, are involved in the reconstruction of $O$ : the surviving manuscripts $A D$, and the lost witness $\alpha$, which can be reconstructed from $B C$. Here, we are able to reconstruct $O$ - in principle, and with exceptions - mechanically: the agreement of two of the three witnesses $A \alpha D$ against the third, corresponds to the reading of $O$.

By now, the first principle of the stemmatic method is clear: the value of a reading depends on the value of the witness that reports it; this value is measured by that witness's relationships of dependence or autonomy with the other witnesses, and is represented by a stemma codicum. For example, in stemma ( $i)$, the value of a $B$-reading is zero ( $B$ is designated as a codex descriptus, that is, derived from another surviving manuscript); the value of an $A$-reading is very high, and equal to an $\alpha$-reading; the value of a reading of $C$ alone or of $D$ alone is low, but if the same reading is present in both $C$ and $D$, it reports a reading of $\alpha$, whose value is equal to that of an $A$-reading.

Therefore, a genealogical representation of the relationships between witnesses provides a powerful guide for textual reconstruction. The subjectivity of the textual critic is strongly limited and replaced by mathematical criteria, apparently more "scientific" and "objective". The cases in which scholars are supposed to choose (by making recourse to their own iudicium) which variant to adopt, among all those attested in the tradition, are drastically reduced. If the stemma takes shape as $(i)$ or (iii), the unclear cases are only those in which $A$ is opposed to $\alpha$. If the stemma takes shape as (ii), there is no doubt in choosing between the variants, because the $D$ reading is always the best (if its reading has to be changed, the scholar will do so without taking into account the variants of the other manuscripts, but on the basis of different arguments instead). If the stemma takes the shape of (iv), everything is resolved by applying a majority principle, except in the case (which will be rather rare) that each of the three witnesses $A \alpha D$ exhibits a different reading.

Among the advantages of the stemma is that it prevents the use of specious and in fact scientifically fallacious criteria, such as the following.

(i) A reading supported by the majority of manuscripts is not preferable for this reason alone. In the case of stemma (iii), when a common reading of the three manuscripts $B C D$ is opposed to a reading of $A$ alone, the theoretical probability of either of the two readings being original is equal. This is because $B C D$ together represent the lost progenitor $\alpha$, and this lost witness (and only this lost witness) is on the same level as $A$. The fact that $B C D$ are three witnesses and $A$ is a single witness does not confer priority on the former variant.

(ii) The reading attested in older manuscripts is not preferable for this reason alone. The stemmata above do not take into account the date of the witnesses. It is indeed true that an older manuscript is more likely to be "better" than a more recent one, because the greater the chronological gap, the longer the chain of copying (using manuscripts we are no longer able to see) is likely to be, and the longer the 
chain of copying, the more likely a modification of the text. This is, however, a mere statistical projection, not evidence at all. For example, in stemma (iii), the very valuable manuscript $A$ might well be a recent copy of $\omega$, while manuscripts $B C D$ might even be earlier copies; what confers value on a witness is not so much its age, as its independence.

\subsubsection{How to devise a stemma codicum}

As can be seen, the usefulness of the stemma codicum for textual reconstruction is obvious. But how do we devise it? How can we know which of the theoretical configurations we have described above (and the many other possible ones) is historically correct?

The first phase of the genealogical method (recensio) deals with producing the stemma codicum. For this task, scholars use the method of indicative (or significative) error s (or, according to the German expression, Leitfehler, "leading errors"). This procedure was fully described in the second half of the nineteenth century by French scholars, albeit drawing on ideas and principles already introduced before (Reeve 1998, 450; Fiesoli 2000, 393). The method of indicative errors uses as its grouping criterion the innovations produced in the historical evolution of the text, that is, the divergences with respect to its original form. In current philological language, such innovations are often referred to as "mistakes" or "er rors", in contrast to an original form considered to be "correct", regardless of whether these "mistakes" are involuntary errors (actually wrong) or intentional changes (which would hardly qualify as mistakes). The principle is that the "error", by creating a deviation from the original form, indisputably reveals a connection among the witnesses that report it; this does not happen for the "correct" reading. If several witnesses share the same mistake, they are supposed (with certain exceptions) to be connected: the "error" is supposed to have been generated in only one copy and transmitted to every descendant of this copy. The "correct" or original reading, on the contrary, is irrelevant for detecting relationships: many copyists may have accurately transcribed what their models reported, each independently of one another, and the fact that all their copies report the "correct" reading does not prove any connection. Turning back to the genealogical metaphor underlying the stemmatic method, we find here the principle - eugenic, in a way - of the "purity" of the lineage: it was "pure" in the parent, and progressively degenerated and polluted in the descendants. Every deviation is a hereditary taint, transmitted by the first carriers to their own children, and so on to all their descendants; by detecting the taint and its carriers, we can isolate a specific branch of the lineage.

The method of indicative errors is therefore the tool for drawing the stemma, but it is not an easy tool to use. Not every mistake is in fact an indicative error: the latter must fulfil certain requirements, that is, uniqueness and irreversibility. A mis- 
take that is very easily committed (e.g. missing a name within a list of similar names) is not entitled to be evidence of relationship. Several copyists might have made this specific error independently of one another, so it is not a unique error (in philological terminology, monogenetic), and does not prove the existence of a single ancestor for all the manuscripts reporting it. Equally, a mistake that is very easy to correct (e.g. a manifest grammatical oversight) is not an indicative error: one or more copyists might have corrected it, and if we grouped a family of witnesses on the basis of this error, we would risk excluding indiscriminately some witnesses that are actually part of the family. This fact explains why scholars have devoted many studies to the analysis of errors, their typological classification, their genesis, and the possibility of correction by mediaeval copyists (for a summary and bibliography, see Trovato 2017, 52-58).

\subsubsection{A real example}

A non-invented example, which we choose here for its simplicity, is the Apocolocyntosis, the satire Seneca composed in contempt for the Roman Emperor Claudius, who had just died (AD 54). The work is preserved in three main manuscripts, written between the ninth and the twelfth centuries: St. Gallen, Stiftsbibliothek, Cod. Sang. 569 (S); London, British Library, Add. $11983(L)$; and Valenciennes, Bibliothèque municipale, 411 ( $V$; reference editions: Roncali 1990; Eden 1984; studies on the transmission: Russo 1942; Eden 1979). We begin by observing that $S$, the oldest manuscript of the three, has its own errors and therefore may not be ancestor of the other two. At the end of the Apocolocyntosis, for example, a court of gods condemns Claudius to play dice with a pierced box (fritillus). Seneca represents the scene with these verses: "Nam quotiens missurus erat resonante fritillo / utraque subducto fugiebat tessera fundo" [Every time he wanted to throw the two dice out of the resonant box, they both went out because of the missing bottom]. In $S$, the words "missurus erat resonante" are written in the form "missurus fratrae sonante", which does not make sense; the two manuscripts $V L$ report the correct form, which they could not have done if they depended on $S$. Manuscript $V$, in turn, has its own errors, and may not be the ancestor of $L$; and obviously, $L$, which is the most recent, cannot be the ancestor of either of the other two. There is therefore no direct dependency between the three manuscripts.

The most interesting fact, however, is that the manuscripts $V L$ are linked to each other by a genealogical relationship. The evidence is that they share some mistakes. In chapter 10, for example, Emperor Augustus - one of the characters who, in Seneca's story, is judging Claudius - is indignant about the many murders instigated by the recently deceased sovereign: "Sed quid ego de tot ac talibus viris dicam?” [What should I say of these murdered men, so many and so illustrious?], he says. Thus $S$; but in $V L$, instead of "ac talibus" we read a senseless "actibus". 
This is obviously a reading or writing mistake. The fact that this mistake is the same in the two manuscripts proves that it took place in a previous manuscript, from which it was transmitted to these two; they are therefore genealogically connected. In chapter 9, Seneca makes the god Janus (another character) say: "Magna res erat deum fieri: iam Fabam mimum fecisti" [Once upon a time, becoming god was an important thing; now you have reduced it to the faba-mime]. In Seneca's Rome, Faba mimum a theatre performance of the worst quality - was an idiomatic expression used to indicate something despicable, or of no importance. This jargon is supposed to have been incomprehensible to mediaeval copyists, and was hence subject to corruption. So, each of the three manuscripts reads, instead of "Fabam", a more trivial, and certainly erroneous, "famam" or "fama" [fame], a mistake made in a previous manuscript, that is, in a common ancestor of the three. In the same passage, the manuscripts $V L$ share the variant "nimium" [a lot] instead of "mimum". In this case, an uncommon word, mimum, has been replaced by a very common but not quite meaningful one in the context; the error was very easy to make, and the copyists of $V L$ may both have made it independently. It is not a unique or monogenetic error, and on its own - it would not prove any relationship between them.

Using the method of indicative errors, we deduce two conclusions from this evidence: (i) all three manuscripts derive from a common lost ancestor $(\omega)$, where "fama(m)" was written instead of "Fabam"; and (ii) manuscripts $V L$ belong to the same family, derived from an ancestor $\alpha$, where "actibus" was written instead of "ac talibus" (and perhaps "nimium" instead of "mimum", but this case alone would be inconclusive). The stemma codicum of the Apocolocyntosis is therefore the one shown in figure 2.2-5.

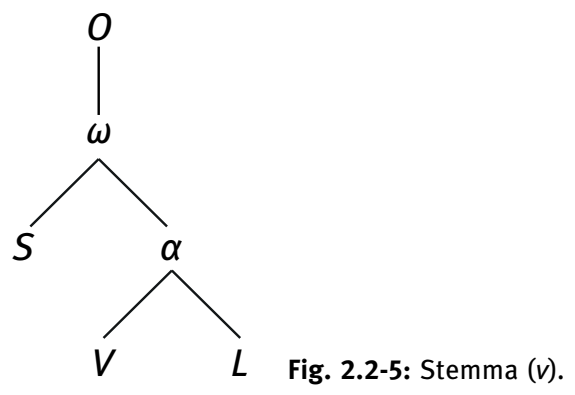

This stemma codicum has several consequences for reconstructing the text:

(i) readings occurring in $V$ alone are supposed to be non-original;

(ii) readings occurring in $L$ alone are supposed to be non-original;

(iii) readings occurring in $S$ alone might be original, because they have the same value as those occurring in $V L$ together (i.e. those occurring in $\alpha$ );

(iv) when the reading of $V$ is the same as $L$, it corresponds to the reading of their lost ancestor $\alpha$, and might be original; 
(v) when the reading of $V$ is different from $L$, and one of the two corresponds to the reading of $S$, the common reading of $S L$ or $S V$ reports the reading of $\alpha$;

(vi) when the reading of $S$ is the same as that of $\alpha$, it corresponds to the reading of their lost ancestor $\omega$;

(vii) when the reading of $V$ is different from $L$, and neither of them corresponds to $S$, the reading of $\alpha$ is uncertain, and the critical editor will have to reconstruct it using other arguments; and

(viii) when the reading of $S$ is different from $\alpha$, the critical editor has to make a choice (selectio) on a different basis in order to recover the reading of $\omega$.

Following these procedures, we are able to determine the text of $\omega$; but this does not yet correspond to the original, for $\omega$ is an archetype, a copy we have above defined as depending on the original but also already affected by innovations or mistakes (as we have seen in the misinterpretation of "Fabam"). This lost manuscript is the highest point in the stemma we are able to reach by examining the surviving witnesses. In the passages where there is certainty, or at least a wellfounded suspicion, that the text of the archetype does not correspond to the original, we can attempt to reconstruct the original by conjecture - an operation called emendatio, "correction". If it is not possible to do so - because the text of the archetype is too corrupt and resists any conjecturing - the critical editor will renounce the task of emendation; the failure of the attempt is usually indicated by inserting a cross (obelus or crux, $\dagger$ ) in the passage. In the case of the Apocolocyntosis, for example, the story apparently lacks continuity between chapters 7 and 8 (as numbered in modern editions): a large part of the text seems to be missing, and the damage was already in the archetype, since the omission is in all the manuscripts of the work. We may have an approximate idea of the missing content, but we can never completely recover the text: therefore, we are forced to resign ourselves to the crux.

\subsubsection{The limits of the genealogical method}

The genealogical method apparently operates on a high scientific level, based as it is on logical rules and standardised procedures. A stemma codicum itself is a geometric diagram, built on mathematical principles, as a visual confirmation of the objectivity of the results. In addition to this, a stemma is a figure very effective in communication: scholars have, in its manuscript tradition, a clear and immediate view of the historical development of the literary work they are studying. Like any schema, however, this effectiveness of representation pays a price for simplification. The need to compress the tradition, as far as possible, into such a schema forces the critical editor to face and uniquely resolve every puzzling or problematic node those nodes that in a discursive and non-schematic presentation might have been 
discussed in detail. "A stemma of the tradition must have historically existed" - a young philologist is likely to think - "and my task is to recreate it at any cost."

As we have said, the stemma figure is borrowed from the language of family descent, as are the metaphors indicating relationships in it. Historically, this borrowing took place from the very beginning of the method, in a fully conscious manner, as shown by the adoption of the key word, stemma, "family tree", which provided the name for the whole discipline. Yet: to what extent do the mechanisms of family descent really correspond to the mechanisms of textual transmission? How widely is the genealogical model legitimately applicable to a manuscript tradition?

The emergence of the genealogical model must be framed in the ideological climate of the time that first expressed it: an aristocratic world where the eugenic concept of "purity" of the lineage was significant. Therefore, in stemmatic descriptions, the "purity" of the text is often a key word: the editor's objective is to reconstruct the "pure" original text, eliminating the "impurities" that have progressively accumulated in it over the course of history. Such "impurities" that "pollute" the text are those produced in its historical evolution: changes made by the copyists either mistakes or voluntary amendments - or material damage to manuscripts. Therefore, the genealogical model implies a degenerative process: the history of a family is the history of a progressive, inevitable, and regrettable departure from the "purity" of race. Applying this pattern to the tradition of the text, subsequent copies always involve a deplorable departure from the original "purity"; those who threaten and corrupt such "purity", the enemy to be fought, are the individual copyists. This eugenic vision, born in connection with the sole purpose of reconstructing the original text, classifies all copyists as ignorant vandals, and prevents the scholar from fully understanding the nature of what they did. In actual fact, the innovations introduced by the copyists are not always the effects of mistakes: they are often attempts to improve a text they considered - rightly or wrongly - incorrect, or to make it suitable for a different audience, that is, their contemporaries. In this fashion, the copyists engaged in the same tasks that face a scholar or critical editor nowadays, though they did so less consciously and with a less sophisticated method. In this view, textual transmission is not only a degenerative history, but may also be a history of recovering and attention.

There is more. There are, in fact, significant and crucial differences between the historical transmission of texts and the principles of family descent, though they have clear similarities in general patterns. The most important element of differentiation is the fact that, while in a family genealogy a child inevitably has only one mother, in the transmission of the texts nothing prevents a "child" from having more than one "mother". Outside the metaphor, a copyist might make his copy using more than one manuscript of the same work as models; in this case, his copy is treated as having more than one "mother". Such an event - always theoretically possible in the transmission of a text, albeit more or less probable depending on the nature of the work, the circles in which it was read, the uses it had - is one of 
the main obstacles to an "absolute" application of the stemmatic method (strenge Stemmatik, to use an expression of Maas). This case is called horizontal trans $\mathrm{m}$ is s i on (because convergent lines can appear in the stemma, unlike a family tree, which contains only divergent lines); using the eugenic paradigm, scholars speak of contamination (see 4.4 below) because the "purity" of the transmission model is spoiled here by the introduction of an external and non-relevant element. Figure 2.2-6 exemplifies the stemma of a contaminated tradition.

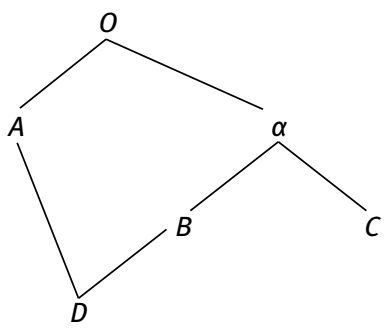

Fig. 2.2-6: Stemma (vi).

This stemma represents a situation where the copyist of $D$ acquired his text from two different models, $A$ and $B$. In this case, the critical editor detects contradictory evidence: witness $D$ shares some errors with $A$, but not all the errors of $A$; witness $D$ shares some errors with $B$, but not all the errors of $B$; witness $D$ also shares other errors with both $B$ and $C$, but not all the errors shared by $B$ and $C$; witness $B$ shares some errors with both $D$ and $C$, but shares other errors only with $D$ and other errors only with $C$; witness $A$ shares some errors with $D$, but not all the errors of $D$; witness $C$ shares some errors with both $B$ and $D$, but other errors only with $B$. Another difficulty is the fact that, if the copyist of $D$ was a clever scribe and was interested in the text he was copying (as is likely, since he is so careful that he uses more than one model for his work), he might have corrected the errors he found in his models: where $A$ was wrong, the copyist of $D$ would have written the reading of $B$; where $B$ was wrong, he would have written the reading of $A$. As an ultimate consequence, witness $D$ might be free of apparent errors, and it might seem to us the best of all the four; from the stemmatic point of view, however, it is the worst, but the derived nature of its text is no longer apparent to us because every indicative error - that is, the tool that would allow us to detect it - has disappeared. Faced in practice with a situation such as that in stemma (vi), therefore, the editor might be tempted to draw a stemma such as the one in figure 2.2-7.

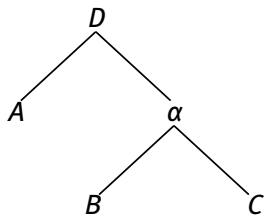

Fig. 2.2-7: Stemma (vii). 
The problem is that, in principle, any tradition might be contaminated, and we have no way of knowing in advance whether it actually is. Therefore, contamination was traditionally considered an a priori obstacle to the application of the stemmatic method, an obstacle so strong that it was supposed to undermine its credibility. Maas considered contamination a disastrous circumstance and an insoluble problem; his sentence "Gegen die Kontamination ist kein Kraut gewachsen” (Maas 1957, 30) [No specific has yet been discovered against contamination] (trans. Flower 1958, 48; other renditions include "no medicinal herb has yet been grown", "there is no remedy") is one of the most famous aphorisms in the history of philology. Again: "im Bereich einer Kontamination versagt die strenge Stemmatik" [where contamination exists the science of stemmatics in the strict sense breaks down] (Maas 1957, 30; trans. Flower 1958, 49). In fact, the recourse by a copyist to more than one model is a historical possibility; as such, it has to be analysed without considering it problematic or disastrous, and it has to be faced using the proper tools of textual criticism. Simply put, such a circumstance is incompatible with the genealogical reference model if applied "absolutely"; but it becomes compatible if the genealogical pattern is used, more correctly, as a metaphor for the mechanisms of textual transmission, without expecting a total coincidence (for a discussion of contamination, with a deeper analysis and some "remedies", see Avalle 1961, 159-178; Segre 1961; Vàrvaro 2010; 4.4 below).

A second element of differentiation between a family tree and the real development of a manuscript tradition is the fact that the former implies uniqueness at the root, which is not necessarily the case for the latter. A family tree starts with a unique parent; a stemma codicum also departs from a unique original, and this unique original is the goal of reconstruction. When, therefore, in the tradition two variants differ, the scholar assumes that one of the two is "true" (i.e. corresponding to the original) and the other is "false" (i.e. not corresponding to the original); they might actually both be "false" (if each of them is the result of an independent innovation), but can never both be "true", because the original is unique. In historical reality, however, many works originally have more than one version, often made by the author himself over time. We are familiar with such cases from modern literatures, where the richness of documentation makes them readily demonstrable; nevertheless, similar events existed, without doubt in great number, even in ancient and mediaeval literatures. When this case pertains, the dichotomy between "false" readings and "true" readings fails: both of the opposing readings attested might be "true", and their duplicity might be explained by the succession of several editorial stages. Scholars, however, conditioned by the binary process imposed by the genealogical model, tend to classify every variant as "true" and "false"; thus, they first (in the recensio) draw the stemma on the basis of the readings categorised as certainly "false", and then eliminate (in the constitutio textus) the others categorised as likely "false". But, in the presence of a uthorial variants, such categorising is undue, because the tradition is not at all unique, and all readings might be "true". 


\subsubsection{The value of the genealogical method}

As noted, the genealogical method originated from the need to base reconstruction on scientific and objective criteria, reducing as far as possible the subjectivity of the editors. In its golden age - namely in the second half of nineteenth century - this method was considered to be almost infallible due to the power ensured by the apparent rigour of the process. It was then restricted and even discredited, both because of its difficult application in certain circumstances (as we described above: contaminated traditions, traditions with authorial variants) and, above all, because of its nature as a reconstructive method, only capable of producing a text that is merely hypothetical. Maas's Textkritik, which, as we have said, is a systematic exposition of the subject, a kind of late manifesto, also met the need to dismantle criticism and to reiterate the validity of the method.

From a balanced perspective, the "scientific" aim of the method seems to have been achieved, and it does not seem to be greatly affected by the aforementioned limits. The genealogical method provided some key concepts for the analysis of the transmission of texts. Moreover, the method elaborated some principles and tools which have value in themselves and are applicable to a significant number of textual traditions, fully or in part. Indeed, the method has endowed textual studies with an essential diachronic perspective. It could not completely eliminate the editor's iudicium - nor was this possible - in choosing the variants; but it has provided editors with an indispensable guide in exercising their iudicium. Discovering some limits of the genealogical method and discussing them has produced greater selfawareness, and has given scholars a more mature and refined method. The objective limits we have recalled do not undermine the general validity of the system.

What is clear today is that the genealogical model, in its entirety, can be applied to specific textual traditions. Considered as a metaphor, however, the model does correctly explain many mechanisms and unravel many situations. The genealogical mechanism is the proposition of a basic principle which has an intrinsic and absolute value and corresponds to real phenomena, though it is rarely (or perhaps never) accomplished in a complete way. It describes the in vitro trend of textual transmission: the basic mechanism, the one that governs the process in an ideal situation. Real situations are obviously much more complex, but they can be interpreted only in the light of the idealised situation, the one where no accidental elements appear. If I am allowed to call into question a further pattern, the "absolute" stemmatic method "in a strict sense", (Maas's strenge Textkritik), might be likened to "uniform motion in a straight line", the rules of which constitute a basic lesson in kinematics: this kind of motion does not exist in nature (as movement is always influenced by other forces, such as friction or gravitation), but knowledge of the "ideal" law makes it possible to clarify every similar real motion.

The scarcity of stemmata in the introductions to today's editions of classical texts may seem surprising: this is generally due to the tradition of these works being 
too complex and having a much too irregular trend, far from a standard genealogical model, to be fully represented by a stemma. Yet the scholars who created these editions have almost always used the stemmatic method for analysing the tradition and for determining some important points in a text's history: for example, for the elimination of some codices descripti or for the identification of some families of witnesses. Going back to the example of the Apocolocyntosis, the stemmata we see in the current critical editions (Eden 1984, 25; Roncali 1990, x) actually reproduce the relationships between the three ancient manuscripts we quoted: the later tradition, consisting of about forty humanistic manuscripts, strongly interpolated and often contaminated, is not provided in detail and only partially appears in the stemmatic representation. The genealogical method served to disentangle some knots, and in this case the decisive knots; in the face of a more complex reality, it could not solve everything.

It is becoming rarer and rarer for today's editors - especially the editors of mediaeval texts, for which the scholarship is more recent and which have therefore benefited from a more refined genealogical method - to present vertical trees that only contain diverging branches, as is expected in a strictly genealogical pattern. Confirmed cases of horizontal transmission are becoming more and more frequent, not least because they are no longer exorcised as unmanageable anomalies; multi-root trees are also becoming more frequent. These representations continue to be called stemmata, following the traditional terminology, but are less and less similar to heraldic genealogies and are increasingly distant from Maas's strenge Stemmatik. Nevertheless, genealogical principles remain the only effective tool to work with.

Other metaphors and other patterns have been adopted over time: the judicial metaphor, which we have already mentioned (where the critical editor is a magistrate in search of a textual "truth", questioning the various "witnesses", ascertaining the credibility of the individuals, and exercising "judgement" in any doubtful cases); the medical metaphor (where the critical editor is supposed to "cure" a text afflicted by minor or serious degenerative diseases, investigating their causes and attempting to reduce their effects); or the chemical metaphor (where existing manuscripts are compared to streams emerging from an underground river whose original nature has to be discovered by removing impurities absorbed by the water on its journey; Maas 1957, 14-15, trans. Flower 1958, 20; Froger 1968, 268-271; Montanari 2003, 236-240). Other interpretative diagrams have also been proposed, linked to set the ory (Froger 1968, 139-216) and, more recently, to cla dis tic s (see 8.1.1.1) and rhizomorphic representation (Greetham 1996, 99-126; Sargent 2013, 247-251).

No one, however, has so far had the power to overthrow the genealogical model and stemmatic representation - and indeed, each enriches in its own way the descriptive spectrum of textual transmission - perhaps because genealogy is basically the machine language of textual transmission, the matrix which lies as a cornerstone of the real facts, and of our ability to understand them. 


\subsection{Criticism and controversy}

Giovanni Palumbo

"Lachmann's method" and its applications have sparked methodological discussions since its first manifesto, Gaston Paris's introduction to his edition of Saint Alexis, published in 1872 (Paris and Pannier 1872). This section examines the main objections that were raised in the subsequent six decades up to 1934. From the point of view of the history of textual philology, this timespan appears to be coherent and of great importance in many respects. It is also a decisive period for many aspects of a debate between philologists and mediaevalists that extends into the present day, as we shall also adumbrate here. Thus, our presentation aims to be both historical and methodological.

\subsubsection{Background}

The genealogical method - also known as the scientific method, method of common errors, or "Lachmann's method" - was gradually developed during the nineteenth century, most decisively in the 1830s. It was fully formalised only in the first decades of the twentieth century, most notably in Paul Maas's Textkritik (1927). We now know that its attribution to the German scholar Karl Lachmann (1753-1851) is largely unfounded (see 2.2.1). This error (or rather, purposeful ambiguity) hails from Romance philology (Joseph Bédier) and biblical philology (Henri Quentin), and extended later to classical philology and finally to other philologies as well. In reality, Lachmann contributed little to the two main points of the method that would later bear his name: $(i)$ the classification of witnesses on the basis of their genealogical relationship, and (ii) the mechanical application of the stemmatic majority in the preparation of the critical text, especially to guide the choices of the editor in all the cases in which the tradition has preserved two or more varianti adiafore (substantial readings - see 4.1.5 - between which an a priori choice cannot be made). On the contrary, Lachmann once termed the stemma codicum a mere pons asinorum (see Fiesoli 2000, 277, 407). The genealogical method is not, in fact, the fruit of a single scholar's invention but the result of a much more complex process based on collective reasoning initiated by scholars before Lachmann, extended by him and his contemporaries, and refined by later scholars (see 2.4). It is only out of convention that the term "Lachmann's method" persists today (in this volume and elsewhere) to refer to the method of classifying witnesses through common errors (on which, see 2.2).

\subsubsection{The genealogical method according to Gaston Paris (1872)}

The earliest explicit and mature theoretical approaches to the principles of the genealogical method go back to the second half of the nineteenth century, when the 
method began to be applied to vernacular texts. Within the span of a few years, Karl Bartsch's work on the Nibelungenlied (1866), Gustav Gröber's on the manuscript tradition of Fierabras (1869), the "Etudes sur la Chanson de Girart de Roussillon" by Paul Meyer (1870), and, above all, the edition of the Vie de Saint Alexis by Gaston Paris (1872) were all published. The latter had been initiated in 1869 but was interrupted by the Franco-Prussian War. In the introduction to this edition (Paris and Pannier 1872, 7-15), Paris sets out in detail the method he applied, including new developments that distinguish it from earlier editorial approaches that now came to be seen as inadequate due to new scholarly standards (see 7.3.1). Paris criticised editions that only reproduced (with minimal interventions) the text of the manuscript that the editor considered to be the best, as well as eclectic editions in which the editor favoured his own competence and taste when choosing among concurrent readings (for more on types of editions, see 6.1).

While describing the necessary steps to produce the critical text, Paris distinguishes two main stages which require distinct approaches: the constitution of the readings (constitution des leçons) on the one hand and the constitution of the language (constitution du langage) on the other. The former involves what are sometimes called substantial readings in English, the latter accidental ones. Regarding the former (the only one we are concerned with here), Paris highlights the following points (Paris and Pannier 1872, 10-14).

(i) For Paris, the aim of textual criticism applied to allographic traditions (i.e. in the absence of autographs) is that of reconstructing as much and as far as possible the form in which the work left the author's hand. Paris was, of course, fully aware of the fact that his aim can never be fully achieved: textual criticism can approach it to a greater or lesser degree, depending on the nature of the textual transmission (antiquity and completeness of the witnesses, the copyists' attitude towards their models, their provenance, and so on).

(ii) The most basic, but also fundamental, procedure in textual criticism is the systematic comparison of the readings of all extant witnesses. Its general postulate is that two different scribes copying the same text are unlikely to make the same errors or introduce the same innovations (this only happens when the tradition presents certain material and textual features). Comparison of the witnesses, when successful, allows the reconstruction of the text of the lost source from which they derive.

(iii) The goal of classifying the witnesses is to ascertain their reciprocal genetic relationships as well as their relationship with the original.

(iv) In order to classify the manuscripts, the editor must beforehand verify that each manuscript is not copied from another surviving manuscript (textual independence of the witness), as a direct or indirect copy of an extant witness (codex descriptus; see 2.2.4) has no authority in the reconstruction of the original.

(v) Given four witnesses $a b c d$, the editor has to test several genealogical hypotheses $(a+b+c+d, a+z(=b+c+d), a+b+z(=c+d), y(=a+b)+z(=c+d)$, 
and so on; see 2.2). If $a b c d$ are independent copies of the original, each will occasionally stand on its own, but no two will agree. If $a b$ on the one hand and $c d$ on the other frequently agree ("coïncidence habituelle"; Paris and Pannier 1872, 12), it has to be concluded that each pair derives from a lost copy $(y(=a+b)+z(=c+d))$ that contained all the shared (monogenetic) innovations and typical readings of each pair.

(vi) The classification of the witnesses can lead to more or less reliable results. The principal obstacles to a well-founded classification are the loss of many mediaeval manuscripts and the quality of what we have lost: in most cases, not only the autographs but also the earliest generations of copies are lost. Frequently, only a single witness survives for a given textual family, and everything that can be said about its lost models (generally, not very much) must come from its analysis.

(vii) If the classification brings to light or demonstrates the existence of three (or more) independent families, the critical text is likely to be established mechanically to a very large extent ("une opération pour ainsi dire mathématique"; Paris and Pannier 1872, 13 [a so to speak mathematical operation]), as long as there is a consensus of the majority, for example two families vs the third (varianti adiafore occur only when all the families independently diverge in the same locus). In contrast, when the classification establishes only two independent families, the editor may decide to give preference to one of them, or decide to employ iudicium (see 6.2.3), to resolve cases of such varianti adiafore. This part of textual criticism is the one in which the "savants vraiment supérieurs" (Paris and Pannier 1872, 13) [the truly great scholars] are revealed.

It has been rightly observed that Paris in 1872 " $n$ 'était pas ce qu'on appellera plus tard lachmannien” (L. Leonardi 2009a, 276) [was not what would later be called a Lachmannian]. His groundbreaking edition certainly affirms clearly, and probably for the first time, the basic principle according to which the genealogy of witnesses can only be established by the method of common errors (Reeve 1998, 450-465). However, his views are not exempt from oscillation and inconsistencies (relatively common at his time) on some key points of the method, which highlight a few fundamental problems:

(a) the limits to the applicability of the stemmatic method and the varying degree of reliability of the results it can attain, both in the classification of the witnesses and in the preparation of the critical text (points (i) and (vii) above);

(b) the possible relationship between shared errors (point (i)) and shared series of variant substantial readings (point $(v)$; see also 2.3.4.4), that is, series of nonerroneous readings shared by two or more witnesses and not all the others, and their relevance for classification; and

(c) the tension between mechanical application of the stemma and recourse to the editor's competence (iudicium; point (vii)).

In the decades following the publication of Paris's Saint Alexis, after a period in which the method of common errors seemed to assert itself in an undisputed way, 
the critical debate resumed in an especially fertile and animated manner. In this debate, the nature and the ultimate goal of textual criticism was dramatically challenged (point (i)). In just a few years, several seminal works had been published. These works have also had the merit of crossing frontiers between disciplines. We shall discuss the most important ones in chronological order:

- 1913, Joseph Bédier's second edition of the Lai de l'ombre;

- 1926, Henry Quentin's Essais de critique textuelle;

- 1927, Paul Maas's Textkritik;

- 1928, Joseph Bédier's "Réflexions sur l'art d'éditer les anciens textes”; and

- 1929, Giorgio Pasquali's review of the Textkritik, which would grow into the monumental volume Storia della tradizione e critica del testo (1934).

\subsubsection{The method of common errors: Ineffective?}

The first radical criticism of the meth od of com mon er rors came from Joseph Bédier and Henri Quentin, two scholars from different fields - Old French and biblical philology respectively - both dealing with "living" textual traditions. They were engaged in an ongoing dialogue, both in private and in public (cf. Quentin 1926, 147-164; Bédier 1928), and found themselves agreeing on the defects of the method (some of them real, others just presumed by them), but they disagreed fundamentally about possible remedies.

Despite their fundamental criticism of it, each continued to remain (as we shall see) in the orbit of the genealogical method. Bédier drew attention to the weaknesses of the method of common errors and its dire consequences when wrongly applied. Quentin tried to modify the foundations of the method, radically changing the procedures of recensio and grounding them in a different set of principles. Each in his own way initiated significant lines of research which have subsequently led to profound transformations arising from their work.

\subsubsection{Bédier’s anti-Lachmannism}

Although a disciple of Gaston Paris and later his successor at the Collège de France, Bédier would fight "la méthode usuelle [pour le classement des manuscrits], inventée, semble-t-il, par Karl Lachmann” (1913, xxiii) [the usual method [for the classification of manuscripts], apparently invented by Karl Lachmann] on the basis of his personal experience in the study of a short mediaeval French text, Jean Renart's Lai de l'ombre (for more on Bédier, see 7.3 .2 below; Corbellari 1997; C. Baker et al. 2018). In 1890, Bédier first published this short poem, diligently applying the method of common errors and constructing a bipartite stemma. Paris reviewed (1890) the edition immediately and praised Bédier's instinct, which led him to nearly always 
choose the good reading in cases where the two families disagreed. Nevertheless, Paris proposed altering the bipartite stemma to make it tripartite (the first stemma is reproduced in fig. 4.1-6 below).

Two decades later, when he returned to the Lai de l'ombre, Bédier began ruminating on the teachings of his by then deceased master, Paris. In his second edition (1913) and in an article (1928), Bédier proposed a law whose main effect seems to have been to render the work of Lachmannian editors arbitrary in most cases, and to create general puzzlement among Lachmannians. The study of a textual tradition seemed to lead the editor always, or nearly always, to draw a bipartite (see 4.1.4) stemma: one in which exactly two surviving branches issue from the archetype. Having finished the editorial work, editors would thus (nearly) always find themselves in the situation of having to choose among differing variants by relying on taste or intuition - subjective criteria, precisely what the method of common errors endeavoured to eliminate. What Paris saw as one possibility among several, became an embarrassing norm in the eyes of Bédier. In the introduction to his 1913 edition, he described a marvellous forest of bipartite trees that grow in the introductions of critical editions. Bédier concluded this was a consequence of editors' unconscious desire to control their editions and to exercise their judgement in establishing the text. Editors, Bédier believed, aspire to be free from the "loi d'airain”, or unyielding law (Bédier 1913, xxxi; 1928, 174-175), imposed by the tripartite stemma. In his 1928 article, he added interesting considerations about the binary logic ("good" vs "bad" readings) at the heart of the method of common errors.

At times, Bédier's scepticism seems to concern the stemmatic method as such. For him, very few stemmata are necessarily certain ("nécessairement vrai[s]"; Bédier 1913, xxxiv). A high degree of uncertainty in assigning witnesses to families seemed to him to be common, at least in vernacular textual traditions. The method of common errors allows the identification with a high degree of certainty of the principal groups of witnesses in the lower branches of the stemma, but fails to do this equally well for the relationships between those groups, that is, when trying to establish the stemma's upper branches. Ascending the stemma, the obvious errors become fewer and fewer, and the choice between competing readings becomes more delicate and subjective; readings that seem innovatory to one scholar might seem preferable or even original to another.

In some cases, an error that seems to define a group of witnesses may not be exclusive to that group: it could, for instance, go back to the archetype and have been corrected in the ancestors of the other groups. In other cases, it is possible that two conflicting readings are both original: the author himself may have revised his work. Bédier also observes that the absence of shared errors from two or more witnesses makes it impossible to prove their parentage, but at the same time does not guarantee their independence.

Bédier's arguments can be reduced to two major points: (i) a text should not be reconstructed with a stemma which is not the only one possible, and (ii) the stemma 
that allows one to ascertain the value of the readings rests on a petitio principii, that is, the discernment of "good" and "bad" readings (see Contini 1939b, $151=1946$, 129). Therefore, Bédier judges the method of common errors to be ineffective and harmful. It is ineffective because it does not allow the reconstruction of the author's text with certainty. The harm comes from the editor being forced to mechanically combine readings from different witnesses under the rule of a stemma that cannot be certain; as such, the stemma could be replaced by others that are equally plausible and equally hypothetical, so that no reasoned choice is really possible. The method eventually produces composite critical texts that are highly arbitrary and that are based on no historical reality whatsoever. Put differently, for Bédier the method of common errors gives the editor the illusion of reconstructing the original text but in reality often just fabricates a new version of it. In contrast, "mediaeval editions" were at least prepared by the copyists to satisfy their audience. From this follows Bédier's editorial scepticism: cease reducing the variants ad unum in order to restore the original text. Instead, choose a good manuscript and keep to its readings as faithfully as possible, correcting only its most glaring errors. If a work is extant in various versions or traditions (recensions), prepare as many editions as there are recensions. In this case, according to Bédier, it is best to publish a good manuscript for each recension, possibly providing an apparatus of the variants from other witnesses containing the same recension.

Bédier thus tries to channel the editorial freedom he had gained from the "loi d'airain" imposed by incorrect or uncertain stemmata towards proper respect for a historical document (a "bon manuscrit"). At the same time, the scope of the edition changes: it is no longer the reconstruction of the authorial version but the publication of one or more scribal versions.

\subsubsection{The genesis of Bédierism from musicology to textual criticism}

Bédier's anti-Lachmann rebellion matured after Gaston Paris's death (1903), and belongs in the context of Bédier's general tendency to radically review his teacher's theses, not only in philological fields but also in historical and literary ones. Mu si cology played an important role in the genesis of Bédier's philological thought (Zinelli 2018). Before his second edition of the Lai de l'ombre, Bédier published a "Lachmannian" edition of the Chansons de croisade (1909) in collaboration with the musicologist Pierre Aubry, then a second, revised edition of Colin Muset's poems (1912), this time collaborating with the musicologist Jean Beck. In mediaeval music witnesses, the manuscripts of the same poem may be accompanied by different melodies. Bédier observed that musicologists do not reconstruct stemmata for the various melodies and their variants (for more on musicology, see 8.4). They do not combine elements from extant melodies in search of an "ur-composition" but instead classify these melodies as "versions", then publish them separately as if they were different originals. The affinities with Bédier's proposed editorial methodology of 1913 and 1928 are evident. 
Bédier's musicological experience can help to understand the genesis of Bé dier ism; the gulf between Bédier and Paris can be gauged by the comparisons they drew with archaeological restoration. Paris writes in the introduction to the Saint Alexis: "J'ai essayé de faire ici pour la langue française ce que ferait un architecte qui voudrait reconstruire sur le papier Saint-Germain des Prés tel que l'admira le XI ${ }^{\mathrm{e}}$ siècle" (Paris and Pannier 1872, 136) [I have tried to do here for the French language what an architect who wants to reconstruct on paper Saint-Germain-desPrés as it could be admired in the eleventh century would do]. Bédier responds implicitly to this assertion by including a quotation from the archaeologist AdolpheNapoléon Didron in his edition: "Il faut conserver le plus possible, réparer le moins possible, ne restaurer à aucun prix” (Bédier 1913, xlv; 1927, ix-x) [One must conserve as much as possible, repair as little as possible, and never restore at all]. In this dialogue à distance between pupil and master, there is a clash between two approaches to restoration that are completely opposed in method and goal: restoration of the monument in the closest possible form to that of the original vs a conservative restoration of only one snapshot of the monument in time.

\subsubsection{The shadow of Bédier and his complex legacy}

The fertility of Bédier's warnings, but also their limitations, were quickly recognised and sparked a lively debate. There is no doubt that his contribution to challenging a primitive and overly simplistic version of the method of common errors (one that was seen as mechanically producing certainty) is to be counted among his merits. Such a simplistic version of the method was what the young Bédier subscribed to at the beginning of his career and what he characterised thus:

Réunir tous les manuscrits discordants d'un même ouvrage; déterminer, par l'observation des fautes communes aux divers scribes, les rapports de dépendance qui groupent certains d'entre eux en familles; opposer ces familles; reconstituer, par la comparaison des leçons divergentes et selon des procédés presque mécaniques, le manuscrit original perdu; puis, quand on a retrouvé cet archétype, rechercher, grâce à l'examen des rimes, de la mesure du vers et des traits linguistiques, en quelle province, à quelle date, l'œuvre a été composée; restituer aux idées le tour qu'elles avaient dans l'esprit de l'auteur, aux mots la forme dialectale qu'ils prenaient sur ses lèvres; établir le texte ne varietur, à peu près tel qu'il serait, si le vieil écrivain avait connu l'imprimerie et s'il avait, de sa main, corrigé ses épreuves: c'est une tâche possible, voire facile. Elle requiert moins encore des dons d'esprit supérieurs que des qualités morales, la patience, la probité de l'esprit. (Bédier 1894, 912)

[To collect all discordant manuscripts of a single work; to determine by the observation of errors common to different scribes the relationships of dependence that group some of them into families; to contrast these families; to reconstruct by a comparison of the divergent readings and according to nearly mechanical procedures the original lost manuscript; then, when one has retrieved this lost archetype, to study through the examination of rhymes, the measurement of verse and linguistic traits, where and when the work was composed; to reconstitute the ideas to what they were in the mind of the author, his words to the dialectal form they had on his lips; to establish the text ne varietur, more or less the way it would have been if 
the ancient writer had known the printing press and if he had with his own hands corrected the proofs: this is a possible task, indeed an easy one. It requires even less the gifts of a superior spirit than moral qualities: patience, probity of the spirit.]

Once these excessive certainties were demolished, Bédier's main flaw was "di non accorgersi che un'edizione critica è, come ogni atto scientifico, una mera ipotesi di lavoro, la più soddisfacente (ossia la più economica) che colleghi in sistema i dati” (Contini 1939b, 151 = 1946, 129-130) [not realising that a critical edition, like every other scientific deed, is a mere working hypothesis: the most satisfactory one (that is, the most economic one) that connects the data into a system]. In other words, a critical edition represents not the ultimate truth about a text but the best possible solution that the editor was able to find for a textual problem. Where the uncertainties cannot be eliminated, it is the duty of the editor to look for what is most probable. But the probable must not be presented as certain. Rather, the status of things and the reasons for and against a given conclusion should be clearly expressed. What is subjective is not necessarily arbitrary. As in all science, a working hypothesis can be replaced by another more satisfactory one - this guarantees the progress of science.

Despite his vigorous anti-Lachmannism, Bédier's process of philological reflection did not develop in a linear, teleological manner (see Palumbo 2018). The programmatic declarations in his editions are not entirely consistent with their rather uneven implementations in his editorial practice. In the same years in which he heavily condemns the method of common errors and challenges the validity of twobranched stemmata (Bédier 1913, 1928), Bédier considers Theodor Müller's bifid stemma of the Chanson de Roland as "vrai" (Bédier 1921, vi) [true] and trustworthy. He uses it for his own edition of the poem (Bédier 1921, 1927). He also insists that it is essential to proceed to the classification of the versions of a text because otherwise "la notion de l'authentique et du primitif se brouille" (Bédier 1927, 83) [the notion of the authentic and of the primary becomes blurred]. In the 1928 article, Bédier reproaches Quentin for not having tried to "tracer les lignes de faîte du schéma, celles qui doivent relier les manuscrits réels à l'archétype” (Bédier 1928, 331) [trace the lines at the top of the schema, those that must connect the real manuscripts to the archetype], for not having taken care to "peser les variants" (Bédier 1928, 329) [weigh the variants] in order to constitute the subgroups, for not having applied the criterion of the "faute commune" [shared error] to group the manuscripts. Thus it becomes clear that, at least partly: "la polemica di Bédier si svolge all'interno, non, come parrebbe, all'esterno della prospettiva lachmanniana” (Segre 2001, 89) [Bédier's polemic develops within and not, as it might seem, outside the Lachmannian perspective]. Therefore, it is hardly surprising that his rich and fertile and partly contradictory legacy would be received in two radically different ways. Responses to his legacy have thus resulted in a fairly clear-cut philological geography (see Duval 2006). 
On the one hand, Bédier's scepticism has been a stimulus to renewed reflection on the stemmatic method. His highlighting of the frequency of two-branched stemmata sparked a long-lasting and important discussion of the reasons why this is so, involving historical reasons, statistical ones, and ones linked to methods of study or to contamination (for bibliographical details, see 2.4.3 below; Haugen 2016). Moreover, Bédier was absolutely right in observing that ascertaining the stemma's lower branches is often easier while the connections between the highest branches are almost invariably less certain. He was also correct in warning against treating partially confirmed stemmata as if all their branches were equally secure. It is indeed possible that a tradition may not contain enough certain elements for a complete classification of all witnesses: the full solution of such problems depends not only on the scholar but also on the data he has at his disposal. Bédier was also right in recommending making several editions of different recensions, especially but not only when there is suspicion that they are authorial, or being content with the publication of one manuscript that enjoyed especial prestige if the data to reconstruct the original text is lacking. His suggestion of concentrating not only on the original text is also of importance: scribal versions (see 4.1.6 on vulgates) should instead be studied in their own right. In other words, his admonition to focus on understanding the copies themselves and changes in their own historical, cultural, and literary life, rather than seeing them merely as a means to reconstruct the original, is significant. An edition focused on a manuscript may be as justified as one focusing on the author; between the two, there are editions focusing on the textual tradition (see Altschul 2006; Beltrami 2010, 112-116, 121-150; Squillacioti 2011, 39; Palumbo and Rinoldi 2015, 70). All these admonitions have been assimilated by the stemmatic method: they have contributed greatly to making it more differentiated and more cautious in its application, and have enabled broader possibilities for editorial success (see 2.3.6 below, 2.4 below; Vàrvaro 1970).

On the other hand, Bédier's scepticism has frequently been oversimplified and erroneously interpreted as an editorial short cut that can be applied to all cases. This has produced a philological practice in which the systematic study of a textual tradition is no longer seen as essential for editing it consistently. This practice, with its apparent advantage of considerably simplifying the editor's work, has over time led to a separation of textual criticism and the study of the history of the text (see 4.5). According to this unsophisticated and comfortable Bédierism, it is sufficient to choose what seems (according to varying criteria) to be a "bon manuscrit" (see 7.3.2). This rather vague and problematic notion may mean a complete manuscript, or an old one, or one linguistically close to the author, or one with few dialectal features, or one that offers a possibly reworked text but that is in general correct, or one that contains errors that are easy to correct - sometimes it may even just be one that is easy to read, or easily accessible, or of artistic value. Thus, a "bon manuscrit" does not necessarily have to be the best manuscript, which would contain the text closest to the original, something that can only be determined after a thorough 
and complete study of the textual tradition. Instead, in this method, once the "bon manuscrit" is chosen, the editor has to reproduce its content scrupulously and to correct only the most obviously faulty readings in such a way that the resulting text is comprehensible.

\subsubsection{Beyond Bédierism: Diachrony vs synchrony}

This different receptions of Bédier's legacy have thus produced a deep chasm in the philological world. On the one hand, there are scholars who claim that the study of the textual tradition is still essential to preparing a critical edition, whatever the type. On the other, there are scholars who consider this an optional and accessory part of editorial work. A conception of philology as the diachronic study of a textual tradition is thus contrasted with manuscript philology concentrated on synchronous aspects of a single witness (cf. L. Leonardi 2011, 2014). This chasm is much more significant than the now rather superficial one that had long been the focus of discussion between "interventionist" or "reconstructive" editors (generally seen as followers of Lachmann) and "conservative" ones (generally seen as followers of Bédier). In the late 1980s, the so-called New Philology radicalised the synchronous approach.

\subsubsection{Old philology vs New Philology}

At the origin of the N e w Philolog y movement is Cerquiglini's Eloge de la variante (1989), inspired by two muses: French theory (Roland Barthes, Jacques Derrida, and others) and informatics (see 7.3.4). Cerquiglini claims that the nineteenth-century philological paradigm is inadequate for editing mediaeval texts and, more generally, for understanding mediaeval textual culture, because it is based on two anachronistic, modern notions: that of the author and that of the text as a definite and discrete entity (see, in contrast, Vàrvaro 1989). According to Cerquiglini, mediaeval literature is an "atelier d'écriture" [writing workshop]: "l’œuvre littéraire, au Moyen Âge, est une variable" (Cerquiglini 1989, 57) [a literary work in the Middle Ages is a variable]. Its primary characteristic is vari a n ce, on the basis of which Cerquiglini (1989, 111) intends to reconstruct historical and genetic development. Faced with two variant readings:

Il ne convient pas de rechercher lequel [= énoncé] est le plus proche de l'“original” (réflexe du philologue), ou bien quel est le plus ancien (réflexe grammatical): il faut poser leur équivalence, et saisir la langue médiévale dans le balancement qui va de l'un à l'autre. (Cerquiglini 1989, 108)

[It is not appropriate to seek which [= reading] is the closer to the original (the philologist's reflex), or which is oldest (the grammatical reflex): one must accept their equal value and grasp the mediaeval language in the swinging that goes from one to the other.]

From this point of view, clearly, none of the traditional editorial methods is able to adequately represent the textual flow of mediaeval works. For Cerquiglini, the solu- 
tion is in an on-screen presentation: "l'ordinateur, par son écran dialogique et multidimensionnel, simule la mobilité incessante et joyeuse de l'écriture médiévale, comme il restitue la prodigieuse faculté de mémoire de son lecteur, mémoire qui définit sa réception esthétique” $(1989,115)$ [the computer, with its dialogic and multidimensional screen, simulates the incessant and joyous mobility of mediaeval writing, and it restores the prodigious faculty of memory of its reader, which defines its aesthetic reception].

The edition he envisages is

une édition électronique fondée sur une numérisation scrupuleuse de ses objets, et sur leur commentaire infini: affichage syntagmatique des éléments signifiants internes au codex, liens paradigmatiques des éléments variants (autres versions), gloses interdisciplinaires diverses. (Cerquiglini 2007, 5)

[an electronic edition founded upon a digitisation which is scrupulous with its objects and their infinite commentary: a syntagmatic display of the significant elements within the codex, the paradigmatic links between varying elements (other versions), diverse interdisciplinary glosses.]

American New Philology (Nichols 1990) shares, by and large, the paradigm proposed by Cerquiglini, which inspired it. This "renewal" of philology establishes two aims:

On the one hand, it is a desire to return to the medieval origins of philology, to its roots in a manuscript culture, where, as Bernard Cerquiglini remarks, "medieval writing does not produce variants: it is variance". On the other hand, a rethinking of philology should seek to minimize the isolation between medieval studies and other contemporary movements in cognitive methodologies, such as linguistics, anthropology, modern history, cultural studies, and so on. (Nichols 1990, 1)

In other words, “the 'new' philology sets out to explore [manuscript culture] in a postmodern return to the origins of medieval studies" (Nichols 1990, 7). This approach kindled a heated debate that has demonstrated its merits but also its numerous limitations; it has also shown that it is not so novel after all (see Busby 1993; Glessgen and Lebsanft 1997). A few years later, the New Philology was relabelled as Material Philology (see Westra 2014), and began to emphasise and specify more strongly its interest in manuscripts:

Material philology takes as its point of departure the premise that one should study or theorize medieval literature by reinserting it directly into the vif of its historical context by privileging the material artifact(s) that convey this literature to us: the manuscript. (Nichols 1997, 10-11)

From the editorial point of view, this postmodern return to manuscript culture has led to online libraries of digitised manuscripts (such as romandelarose.org) and/or to "imitative" transcriptions of single manuscripts (cf. e.g. Willingham 2007, 2012), preferably ones with miniatures or glosses, chosen as examples of "a collaborative 
effort bespeaking the social, commercial, and intellectual organization of a specific moment in time" (Nichols 1997, 12). The central figure - "hero" in Cerquiglini's words - of Material Philology is the s cribe, as opposed to the a u thor; but ignoring the diachronic perspective and not studying the textual tradition, sometimes aggravated by the editor's lack of the necessary linguistic and philological knowledge, opens the floodgates to complete relativism, favours misinterpretation, and thus is an obstacle to the appreciation of the specificity of the single witness (see L. Leonardi 2009b; Haugen 2010; L. Leonardi 2011, 2017). Indeed, we cannot understand a scribe's work without considering the sources he used, that is, the work of the preceding scribes. And we cannot understand the work of those previous scribes without considering the author's work.

\subsubsection{Quentin's anti-Lachmannism}

While Bédier exerted a profound influence on ecdotic practices, the same cannot be said of the Benedictine monk Henri Quentin (1872-1934), though his role as a precursor to computer-assisted approaches is generally recognised. He wrote a study called Les Martyrologes historiques du moyen âge (1908), and took part in the commission chosen by Pope Pius X to establish the critical text of the Vulgate Bible. The task was monumental. There were two principal obstacles, one qualitative, the other quantitative. The text of the Vulgate was continually revised, corrected, and modified by the scribes - one might speak of a "living" textual tradition; at the same time, the quantity of witnesses is enormous. Faced with such a complex textual tradition, earlier scholars judged a classification of the witnesses to be impossible and turned to the analysis of single variant readings for the reconstruction of the text (see Tov 1982). Assessment of the witnesses and their agreements was relegated to the background. For Quentin, however, the classification of witnesses was unavoidable and of great importance if textual criticism was to avoid becoming a purely subjective art exercised in a more or less virtuoso manner by the editor. But how could all these manuscripts be classified? Quentin agreed with much of Bédier's criticism of the method of common errors. He especially emphasised the vicious cycle of judging a reading "good" or "erroneous" based on the idea one has of the original text and of what the author might have written or not. But he disagreed completely in his approach to remedying the failures in Lachmann's method. He condemned absolutely an editorial practice that consists of adopting one manuscript chosen without fixed rules, to be corrected here and there when it seems necessary or opportune, according to the subjectivity of the editor. Quentin intended to revise the genealogical method, not to abandon it: a classification of the witnesses is necessary for a rigorous critical approach. While Bédier aimed to free editors from the fallacious "loi d'airain" of stemmata, Quentin believed, instead, that a new "règle de fer", an iron rule, could make recensio fully objective. 


\subsubsection{Quentin's “règle de fer"}

Quentin's innovative ideas were first set out in his Mémoire sur l'établissement $d u$ texte de la Vulgate (1922), then more succinctly, albeit with a greater variety of examples, in Essais de critique textuelle (1926). Quentin distinguishes two phases, each requiring its own procedures. First, the reconstruction of the text of the archetype, classically understood as the codex from which all extant witnesses descend (see 4.1.1). Once the archetype's text is established, one can approach the original's text, that is, the one written by the author. The study of the witnesses allows one, at best, to reach the archetype, which, however, may be full of errors of all kinds. This is why the distinction between "good" and "erroneous" readings is avoided in this phase of recensio, as it would make sense only with respect to the original, not the archetype. From the point of view of the archetype, two differing readings are neutral: whether "good" or "bad", they have the same probability of being in the archetype (the archetype might have had either a "good" or a "bad" text in this locus) or being innovations with regard to the archetype. In other words, a "good" reading is not necessarily an "authentic" reading, and vice versa. In the first phase of recensio, Quentin thus rejects the notion of "error" itself in the method of common errors. For him, two differing readings are merely two readings that define identities and similarities among and between witnesses. In order to establish the classification of the witnesses, Quentin proposed to collect all divergent readings in a list, then to study the data in the list and to thin out the useless cases using statistical procedures from the experimental sciences, and finally to analyse the results in order to group the witnesses into families. Only when one has thus arrived at families of witnesses, and by establishing the archetype on that basis, does it become possible to proceed to the reconstruction of the original. Only at this point does ecdotics turn into an art in which the editor can use textual criticism, taking care to mark his conjectural interventions typographically in the text.

\subsubsection{Orientation and enchaînement of the stemma}

Quentin's method was inspired by Ernst Bernheim's treatise called the Lehrbuch der historischen Methode (1889). Quentin identifies the witnesses that are most similar to one another by using tables, then compares them in groups of three, always looking for the intermediate one among the three. For instance, given three manuscripts $A B C$, the first goal of the editor is to find the intermediary one, the one that is in agreement sometimes with one, sometimes with the other, but which is never (or very rarely) isolated against the other two. If we find usually $A B$ vs $C$ and $A C$ vs $B$, but (almost) never $A$ vs $B C$, then the intermediate manuscript is $A$. In the table of correspondences, the relation $A$ vs $B C$ will thus receive a value of 0 (or nearly 0 ), in contrast to positive numbers for the agreements of $A B$ vs $C$ and $A C$ vs $B$. Quentin speaks in the former case of a "zéro caractéristique": his "règle de fer" is based on the search for this value. Once the intermediate manuscript for a first series of three has been identified, the first ring in a genealogical chain has been established. The 
comparison can now be extended to a fourth manuscript, then a fifth, and so on, until, ring after ring in place, the entire chain has been established. Thus it is possible to establish the enchaîne me $n t$, "linking", of manuscripts, but not their ori entation, "rooting", or the direction of the chain. In other words, the method allows us to identify a set of relations between the witnesses, but not to interpret and hierarchise them. Returning to the example above, the statistics of the enchaînement leads to $B-A-C$ (or, if one prefers, $C-A-B$ ). The analysis cannot inform us about the chain's orientation, which could equally well be any of the following (see fig. 2.3-1).
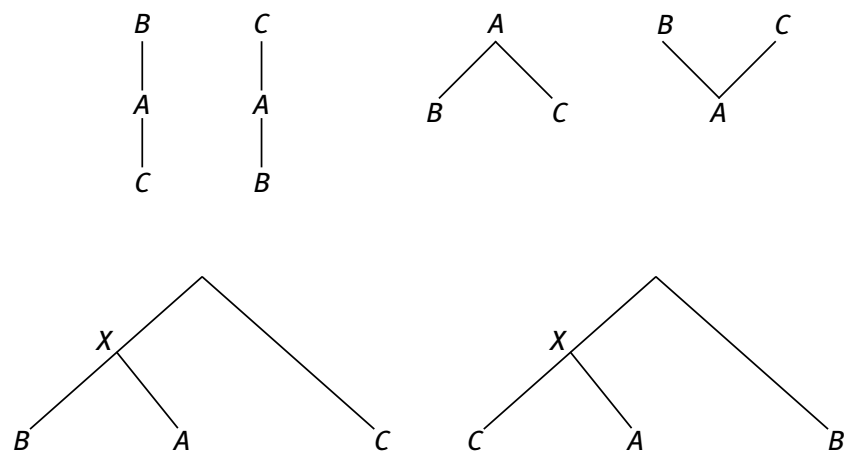

Fig. 2.3-1: Six alternative stemmata with intermediate manuscript $A$.

In order to orientate this chain and hierarchise the diagram (see 5.2.1) - that is, find the point of origin of the manuscripts' genealogy (the archetype, or root; see 4.1.5) it is necessary to evaluate the readings in order to find what is earliest and what is latest. Set aside in the first phase of recensio, qualitative analysis and the notion of "error" have an essential role in the concluding phase of the task of classification, which is also a more delicate one.

\subsubsection{Quentin's method as reviewed by Froger}

Today, Quentin's method seems ingenious but also chaotic. Its most significant logical defect was pointed out in 1968 by another Benedictine, Jacques Froger. If Quentin had counted the disagreements between manuscripts instead of their agreements, his path would have been much more direct:

Il est plus direct de mesurer la "distance", comme le nombre de kilomètres entre deux villes, que la “codistance”, comme le nombre de kilomètres qu'il n’y a pas à parcourir, étant donné la longueur totale du réseau routier d'un pays, pour aller de telle ville à telle autre. (Froger 1968, 46-47)

[It is more direct to measure "distance" as the number of kilometres between two cities than their "co-distance", the amount of kilometres that do not have to be covered to go from one city to another with regard to the length of the total road network of a country.] 
In a manual full of good sense, based on both the logic of scholasticism and set theory, Froger radically revised Quentin's method. He substituted the uneconomical "comparaisons par trois" [comparison in groups of three] with the more efficient "méthode 'par les groupes”" (Froger 1968, 47) [grouping method], whose logical and operative steps he described with great clarity. Significant parts of the study are also devoted to anomalies in traditions, such as fragmentary manuscripts, errors corrected by conjecture, contamination, and so on, and he illustrated the limitations of quantitative analysis and the distortions they may produce. Thus, Froger's study also has the merit of allowing one to appreciate more clearly the methodological innovations introduced by Quentin. In particular, two points seem of paramount importance when comparing their method to that of common errors.

The first concerns the possibility of automating, at least in part, the editor's work by delegating quantitative analysis to a machine. In Froger's book, this is already mentioned in the title: La Critique des textes et son automatisation. The second part is, in fact, devoted entirely to a dialogue between the editor and the computer. This was highly innovative at the time, but it is also inevitably the part of the book that has aged most quickly. The obsolescence of this section has doubtlessly damaged the fortunes of the entire study, though there seems to be renewed interest in it (cf. Poirel 2016).

The second question is in several senses crucial and merits deeper consideration: how a dialectic between shared "errors" and shared series of non-erroneous readings can be achieved in the classification of witnesses.

\subsubsection{Does congruity of readings imply identical origin? A controversial principle}

Let us begin again with the basic principle of the method of common errors as formulated in Paris's Saint Alexis (see 2.3.2): two different scribes who copy the same text neither commit the same errors nor make the same changes unless there is common material or a textual factor that pushes them to intervene in the text in the same way (point (ii)). At the same time (point $(v)$ ), Paris asserts that if, among four manuscripts, two ( $a b$ vs $c d$ ) share a "coïncidence habituelle" in their readings, it must be concluded that they derive from two lost intermediaries $(y(=a+b)+z$ $(=c+d))$. But this second assertion is not true, and partly contradicts the logic of the first. In Paris's fictitious example, the four manuscripts are classified into two groups according to shared readings, without making use of the concept of "error". However, the fact that the tradition attests two contrasting readings for a given passage does not imply the existence of two families, but only of one (the one with the innovative readings, Agreement in original readings cannot serve to join manuscripts into a family, for their agreement is simply caused by a faithful transmission of the text of the original. Of course, the two pairs may both be families, but this can be demonstrated only if the scholar can show that both readings are innovations with respect to the original (which also means that none of the four 
copies preserve the text of the original), as Paris knew very well. In fact, this very situation is encountered when he presents the principles of the method's application (Paris and Pannier 1872, 21-22). The four manuscripts of Saint Alexis often form two contrasting groups: $L A$ vs $P S$. As Paris explains, there are three possible forms of the stemma. If $L$ and $A$ only share "good" readings, their shared readings do not prove that they are a family, because they could have kept the original readings of the archetype independently. We would then get $L$ vs $A$ vs $(P+S)$. If, on the contrary, $P$ and $S$ only agree on "good" readings, we would have $(L+A)$ vs $P$ vs $S$. Only if each group shares at least one erroneous (non-archetypal) reading, will there be two families: $(L+A)$ vs $(P+S)$.

Paris did rectify his methodological slip, but his apparent hesitation is certainly symptomatic. In his era, the reconstruction of the genealogy of the witnesses on the basis of common readings without considering whether the latter were correct (archetypal) ones or not, was widespread. Among the scholars who strongly affirmed that only shared errors (innovations) allow us to discern the filiation of the witnesses was the classical philologist Paul Lejay (1861-1920). He insisted several times that "les fautes seules permettent de discerner la filiation des textes" (Lejay 1899, 144) [only errors permit discerning the filiation of texts]. More precisely, he highlights that

une famille de manuscrits est constituée par leurs fautes communes, ou, si l'on préfère ce terme plus exact, par leurs innovations communes. Ainsi, l'existence d'une série de leçons correctes et authentiques dans plusieurs manuscrits ne peut prouver que ces manuscrits dérivent d'une source commune. Les fautes seules sont probantes. (Lejay 1903, 171)

[a manuscript family is defined by its common errors, or, if one prefers this more precise term, by its common innovations. Thus, a group of correct and authentic readings in several manuscripts cannot prove that these manuscripts derive from a common source. Only the errors are relevant.]

In 1927, Maas went further and affirmed that not all errors are equally significant. Only "indicative errors" can be used to draw the stemma (on the limitations of this definition, see 2.2.5 above, 2.4.3 below; Fernández-Ordóñez 2002).

This clarification was necessary to eradicate dubious philological practices. While he acknowledged the correctness of this methodology, Froger also pointed out its drawbacks. The main one is that the editor who applies the method of common errors

ne peut plus raisonner sur toutes les leçons, mais seulement sur le petit nombre de celles que les critères conjecturaux permettent de regarder avec certitude comme des fautes [...]. On verra dès lors les critiques s'engager dans une voie dangereuse: établir la généalogie des manuscrits à l'aide d'un nombre de fautes ridiculement petit, dans le désir de ne retenir que celles qui sont probantes. (Froger 1968, 42)

[can no longer consider all readings, but only the small number of those that the conjectural criteria allow with certainty to be regarded as errors [...]. Consequently, we will see philologists take a dangerous road: establishing the genealogy of manuscripts with the help of a ridiculously small number of errors, wishing to keep only those that have demonstrative force.] 
The problem is real, especially for "living" textual traditions in which "indicative errors" are often very rare but variants are very numerous and their value is hard to judge. It is no accident that the best philologists or editors of texts have always used a series of substantial variants to confirm their classification or to doublecheck the degree of likelihood of their families in relation to possible alternative groupings (see 2.4.3). The exclusion of non-erroneous variants from stemmatic reasoning deprives the editor of a further means of control which can help to detect an erroneous assessment or perspective. Moreover, this also leads to only a partial view of the textual tradition, including the risk of overlooking relevant indicators. As an example, let us look at contamination by change of exemplar (see 1.2.3, 4.4.4.2), which is a more common and complex phenomenon than one would suspect. Let us say that manuscript $B$ is grouped with $A(A B=x)$ against $C D(=y)$ on the basis of two "indicative errors", one at line 100, the other at line 1200. But imagine that $B$ had changed its model for lines 600-900 to an exemplar from type $y$. If there is no "indicative error" linking $B C D$ in this portion of the text, the contamination will easily go undetected in a classification based only on shared errors. In such a case, considering the series of shared variants would most likely flag up anomalies in the distribution of agreements (if it has shifted to the $C D$ model, $B$ possibly agrees less often with $A$ and more often with $C D$ ) that would challenge the philologist to interpret them. In conclusion, a legitimate objection has been raised against a distorted use of the principle that identical readings imply identical origins, but this must not conceal the fact that the principle of carefully considering the distribution of variants while working on the classification is, in itself, valid if interpreted correctly (see Reeve 2011a, 59). The presence of series of shared readings in two or more witnesses is never without significance. The congruity of readings does imply a common origin, though it does not by itself tell us where to situate it. If a certain number of witnesses share innovative readings, they form a group and go back to the same ancestor, the one that introduced those innovations. If, on the other hand, they share readings that go back to the archetype or to the original, they do not form a group. This decisive piece of information (which of the variants is the archetypal/original one?) cannot come from quantitative analysis, only from qualitative analysis.

From this point of view, Quentin's merit, and even more so Froger's, lay not so much in proposing a method of classifying manuscripts that differed from that of common errors, but much more in consolidating and clarifying within the method of common errors the dialectic between analysis of variants and of errors. Thus, these two scholars awakened interest in contrasting "groupes variants" (witnesses sharing the same readings) with "groupes fautifs" (witnesses sharing the same errors), and they have shown the possible advantages of first reconstructing the enchaînement of the witnesses before tackling their orientation. Thanks to Froger, we have now a clear operational procedure, the application of which may be more or less advantageous and economical depending on the textual tradition in question. 
It has to be judged in each particular case whether it is more advantageous and economical to use judgement right away or whether it is better to postpone it to a second stage of recensio.

\subsubsection{The "Quentin line"}

The Quentin-Froger method anticipates some of the most recent computerised methods of cladistics and phylogenetics applied to texts in that the study of variants can be automated, and also in its two steps in the construction of the stemma: enchainement and orientation. It is no accident that Froger devoted the final pages of his study to the opportunity to confront philological procedures with the then new phylogenetic evolutionary approaches in biology (Froger 1968, 270-271). However, it must be noted that in most recent attempts to use computerised methods, and concepts and tools from phylogenetics, for the classification of witnesses, the computer is not only used to construct the enchaînement of the stemma but is also trusted to orientate the resulting tree, for instance by choosing between the various possibilities using the principles of parsimony (Roelli and Bachmann 2010 is an exception). Such experimental attempts bypass the notion of "error", which does not exist in phylogenetics (see Macé and Baret 2006, 102; 8.1 below). The difference is important: it is not at all clear that a correct inference of the stemma is possible without any qualitative analysis of errors within the recensio, and the efficacy and reliability of such methods is still to be confirmed. Such an assessment will be possible once these new approaches produce scholarly editions so that their results can be tested and confirmed or falsified, as the case may be. For this, the principles of the software involved must be understood in detail, but it must also be stated clearly what kind of input data was used, what information was excluded, and what criteria the software used to orientate the tree. In general, this topic is much too often swept under the rug. So far, editions based on computer-assisted stemmatics do not seem to be very promising (see Trovato 2017, 179-228).

\subsubsection{How is the genealogical method used? Giorgio Pasquali’s post- Lachmannism}

Every stemma codicum has two immediate applications:

(i) a practical one, that of guiding the reconstruction of the critical text; and

(ii) a historical one enabling the reconstruction of the events in a textual tradition.

Maas's Textkritik (1927) expounded the first point very systematically. Pasquali's Storia della tradizione e critica del testo (1934), which grew out of a review of Maas's short treatise, may be the work that emphasises the second most significantly (see 4.5). 


\subsubsection{Textual criticism and the history of a textual tradition}

When Paris formulated the genealogical method (see 2.3.1), he pointed out that the classification of manuscripts may yield more or less certain results depending on the circumstances. For him, the main obstacle was the great loss of witnesses in mediaeval textual traditions. He does not mention other factors that might disturb the vertical transmission of a text and thus the application of the method.

An early synthesis of some of these factors is offered in Louis Havet's Manuel de critique verbale (1911). But the core of this work is dedicated to the genesis of innovations, not the genealogy of witnesses. Still, some paragraphs (§1610-1617) of the last chapter (80, "La classification généalogique des manuscrits") are dedicated to a presentation of the genealogical method and then to the "pièges de la classification généalogique” [pitfalls of genealogical classification]. Havet lists four principal ones:

$1^{\circ}$ au lieu de diverger toujours, il arrive que les rameaux de l'arbre convergent; $2^{\circ}$ dans un texte donné, certains morceaux, voire certains courts passages, parfois certains mots, peuvent avoir une généalogie particulière, autre que la généalogie de l'ensemble; $3^{\circ}$ entre mss. comme entre personnes, il peut se produire des rencontres de ressemblance qui ne viennent pas d'héritage; $4^{\circ}$ les surcharges comportent des interprétations multiples, dont le classement spécial peut contredire le classement généalogique. (Havet 1911, 418)

[(i) Instead of always diverging, sometimes the branches of the tree converge; (ii) in a given text, certain pieces, that is, some short passages, sometimes some words, may have their own genealogy, different to that of the overall text; (iii) between manuscripts, just as between people, there may be resemblances that do not come from inheritance; (iv) additions may permit multiple interpretations, whose special classification may contradict the genealogical one.]

In other words, Havet lucidly points out four obstacles for the logical system on which the method of common errors is based: (i) contamination, (ii) selective collation, (iii) polygenesis, and (iv) corrections.

Pasquali's book returns to all these points with an in-depth and systematic approach including a vast array of examples. At the core of his work are different forms of non-mechanical traditions in which the text is not vertically transmitted from the archetype to the extant copies: cases in which there is more than one archetype at the top of the text's transmission, cases of conjecturing and contamination by scribes, of authorial variants in the tradition, and so on. But with regard to Havet and Maas the perspective is reversed: what appeared to be "pièges de la classification généalogique”, pitfalls for the editor, are now studied as phenomena that are intrinsic in the life of texts. Pasquali's main purpose is to tightly connect recensio (ex parte subiecti, i.e. the philologist's method) to the history of textual traditions (ex parte obiecti, the textual phenomena). He intends to demonstrate that, in order to reconstruct the text of a work by recensio, that is, the comparison and evaluation of witnesses, it is essential to intimately know the vicissitudes the text has suffered from the moment of its composition down to the extant witnesses. Pasquali thus transcends the logico-mathematical approach of Maas's Textkritik by 
transforming the latter's set of abstract logical norms into a historical, applicable method. But he also reviews the approach to textual traditions that are no longer considered the result of a process of textual degeneration. The human activity of the scribes transcribing a text becomes the central focus: sometimes they reworked it unconsciously, but more often consciously, in order to achieve a version that seemed better to them.

The different assessments of contamination may help to gauge the difference in perspective. For Maas, contamination is a kind of virus, or even bug, in the system. In the case of contamination, the method of common errors may end up without defences and stop working, as the famous quotation shows: "Gegen die Kontamination ist kein Kraut gewachsen” (Maas 1957, 30) [No specific has yet been discovered against contamination] (trans. Flower 1958, 49; see 2.2.7 above). For Pasquali, in contrast, contamination is not an anomaly that provokes a crisis in the logical system and a "fatal system error", but rather a well-attested event in the text's transmission that sheds light on how scribes and early editors treated the text of their models and conceived the production of new copies. Pasquali does not neglect to present possible remedies against contamination, but focuses mainly on the questions of why, when, in what way, and where several exemplars of a text were compared by the scribes. One thus moves from a logical and formal point of view towards a historical one that focuses on concrete cases. Textual criticism and the history of the text are joined together indissolubly: it is no longer possible to engage in textual criticism without knowing the specific history of the text in question, that is, without knowing the culture and the modus operandi of the individuals and the groups who transmitted the text and who have left their imprints on it. From this follows Pasquali's conclusion: whenever the tradition of a text is not purely mechanical, whenever the scribes did not just passively reproduce their model, there is no general recipe for editing a text. The editor's work on a text is not mechanical; in order to reconstruct the original text as far as possible, it is necessary to employ judgement from the very beginning, which also leads to a reassessment of the value of internal criteria for evaluating readings with a stemmatic approach (usus scribendi, lectio difficilior).

The volume Storia della tradizione e critica del testo was published in 1934. One year later, 1935, Henri Quentin died. Three years later, in 1938, Joseph Bédier died. A crucial period in critical philology came to an end, and a new one began: one of continuity and renewal.

\subsubsection{Conclusion: "The worst method except all those others that have been tried"}

In the years between 1872 and 1934, from the edition of Saint Alexis to Storia della tradizione e critica del testo, the method of common errors underwent a healthy self- 
examination. Objections raised against it did not sweep it away, but rather made it more conscious of its own fragility and of its strong binding to the judgement of the editor. The task of the editor becomes more difficult but also more interesting: editors now have a better sense of the limitations and risks immanent to their method, and can better protect themselves from any sense of illusory certainty.

The principles on which the genealogical method is founded are still valid: if two witnesses contain one or more substantial errors in the same loci, they most likely descend from a common model, since it is unlikely that they acquired them independently. Once the genealogical tree of the extant witnesses has been traced, the agreement of two or more independent branches demonstrates the archetypal readings, because it is unlikely that they independently introduced the same substantial innovations. The new awareness comes from the knowledge of applying such principles correctly: "per essere oggi lachmanniani, [è] indispensabile aver attraversato un tirocinio antilachmanniano (cioè Bédier) e un'esperienza postlachmanniana (cioè se non altro, in filologia classica, Pasquali)" (Contini 1970, 344) [in order to be a Lachmannian today, it is necessary to have gone through an antiLachmannian (that is, Bédierist) apprenticeship and a post-Lachmannian experience (that is, at least in classical philology, Pasquali)].

From these presuppositions neo-Lachmannism is born, and it has produced some philological masterpieces such as d'Arco Silvio Avalle's edition of Peire Vidal's Poesie (Avalle 1960) or Cesare Segre's edition of the Chanson de Roland (Segre 1971; see 2.4 below). From the Bédierist school, Lachmann's method has, on the one hand, learnt prudence and definitively given up the practice of publishing mosaic-like critical texts, and on the other to draw attention to scribal versions that are of interest in themselves. From Quentin and his successors, the method has learnt to treasure the genealogical information provided by witnesses that agree in a series of nonerroneous variants, and to handle it carefully instead of ignoring it. Finally, from Pasquali, it has learnt the necessity of bringing the method down to earth from the heavens of logical principles with individual historical situations and individual textual phenomena, since textual criticism and the history of the text are bound together and inseparable. The marvellous forest of philological trees consists, in fact, not only of the bifid trees that preoccupied Bédier, but also and especially of trees whose ramifications cross and intertwine with one another in a great variety of ways. From here also follows the awareness that every text poses a specific problem that requires specific editorial solutions, and that different types of editions (see 6.1) can serve different aims (see Vàrvaro 1970). In spite of all possible objections to the genealogical method, we shall conclude with Alberto Vàrvaro's incisive wit:

alla ricostruzione stemmatica della storia della tradizione manoscritta possiamo adattare quello che Winston Churchill disse della democrazia: la stemmatica è un sistema pessimo, ma è il migliore tra quelli che conosciamo. Bisogna accontentarsi e vedere cosa se ne può ricavare. (Vàrvaro 2012, 87)

[we can adapt what Winston Churchill said about democracy to the stemmatic reconstruction of the history of manuscripts: stemmatics is the worst method except all those others that have been tried. We must make do with it and see what we can obtain from it.] 


\section{Acknowledgements}

This section was translated from the Italian by Philipp Roelli. Giovanni Palumbo gratefully thanks Sarah Melker and Nicola Morato for their invaluable help.

\subsection{Neo-Lachmannism: A new synthesis?}

Paolo Trovato

This section addresses some of the most relevant improvements and refinements of the genealogical method following Joseph Bédier's sharp criticisms (see 2.3), that is, from 1929 to the present day. This complex, steadily improved set of procedures, scarcely known in most Western countries, where the method is often associated with its unrefined applications in the nineteenth and early twentieth centuries, deserves to be considered by any scholarly editor because of its effectiveness in treating even very complicated textual traditions, such as that of the Old French Chanson de Roland.

\subsubsection{From Lachmann's method to neo-Lachmannism}

Let us begin this overview with two important, though obvious, remarks ("important” and "obvious” are not necessarily at odds) by Karl R. Popper and G. Thomas Tanselle:

The doctrine of [human] fallibility should not be regarded as part of a pessimistic epistemology. This doctrine implies that we may seek for truth, for objective truth, though more often than not we may miss it by a wide margin. And it implies that if we respect truth, we must search for it by persistently searching for our errors: by indefatigable rational criticism, and self-criticism. (Popper 1965, 16)

Every statement about editing [...] reflects, directly or indirectly, an attitude toward certain fundamental questions, and various families of editorial approaches have grown up over the centuries because these questions have been answered in different ways. (Tanselle 1995, 9)

As can be gleaned from the studies of Timpanaro (1961, rev. ed. 1981, repr. 2004, trans. Most 2005), Kenney (1974), and Fiesoli (2000), the so-called La ch mannian or genealogical method, or method of common errors, "was constructed over a rather long timespan (from the last decades of the eighteenth century to the early twentieth century) thanks to the contributions of many scholars, sometimes working in connection with one another, sometimes working autonomously" (Paolo Chiesa in 2.2.1 above). Key aspects that are today considered fundamental were precisely formulated only several decades after the death of Lachmann, such as the 
criterion that only shared in novation s can serve to prove the kinship between two or more witnesses (the oldest thorough formulation of this principle appears to be that of Lejay 1888; see Froger 1968, 41-42; Reeve 1998, 451-452 = 2011a, 57-58, with additions). Following the research of Reeve, one can also indicate a date for the birth of stemmatics based on shared errors that looks very reasonable, albeit conventional: 1872, that is, the year of the edition of the Vie de Saint Alexis published by Gaston Paris (1839-1903), the completion of which had been delayed by the Franco-Prussian War of 1870-1871. As Reeve puts it, no other editor "can challenge Gaston Paris for the title of the first scholar to have applied systematically the principle that only shared errors establish families of textual witnesses" (1998, $464=2011 \mathrm{a}, 68$ ).

From then on, for nearly six decades, the method of shared errors spread and was applied - often in too naive and mechanical a way - in a variety of fields. Notwithstanding the appearance of the short but very dense treatise of Maas (1927), the party was ended rather brusquely in the second half of the 1920s when the Benedictine Henri Quentin $(1922,1926)$ and the most famous pupil of Paris, Joseph Bédier (1928), directed their critical blows against it (2.3 above). Even though many of their objections do not seem unassailable today, it happened, mostly thanks to the extraordinary argumentative skills of Bédier, that the relatively cohesive world of textual critics began to break up into several families. Classical philologists - who usually worked on texts from a millennium later than their lost originals, offering in many cases at least some easily identifiable common errors - remained in the Lachmannian orbit. North American Romance philologists did so too for several decades, and almost all Italian and several Spanish ones still do today (in Italy, the enormous prestige of Barbi, Pasquali, and Contini has been a decisive factor in this choice of method). In contrast, many biblical scholars (who have to work with overabundant traditions) were attracted by Quentin's theories, and many Romance philologists (both French and other) who dealt primarily with mediaeval French texts quickly sided with the Bédierist camp. They often had to deal with works which lack a strong authorial mark and present hard-to-track errors, and besides, the new method allowed them to produce an edition much more quickly (Foulet and Speer 1979; Reeve 1986 = 2011a, 28-44; Speer 1995; Trovato 2017, 77-108, 289-297; see also the important C. Baker et al. 2018).

The most unfortunate consequence of Bédier's "schism” was certainly the sometimes very heated conflict between the supporters of the different methodologies. Unfortunately, most members of many of these schools and traditions, which originated during the last century, are hardly even able to discuss their mutually incompatible methods with one another - even though textual scholars have become a much-reduced subset of that already small group that still does fundamental research in the humanities and they all basically address the same problems. Be that as it may, what is most important for this section is that Bédier's criticism became a very efficient stimulus for supporters of the genealogical method to reflect on its flaws and review their own positions: 
Sui principi di quello che fu chiamato lachmannismo [...] è seguitata a svolgersi nel secolo e mezzo successivo quell'opera di raffinamento, reazione e revisione per cui si può anche parlare di antilachmannismo (principalmente Joseph Bèdier e dom Quentin), postlachmannismo (così Giorgio Pasquali e in certo modo Michele Barbi) e, perché no?, neolachmannismo (parte della romanistica italiana). (Contini 1977, $995=2007,1: 6$ )

[In the century and a half that followed [Lachmann's age], scholars were busy refining, reacting against, and revising [...] the principles of what was later called Lachmannism, so that we can also speak of anti-Lachmannism (first of all Joseph Bédier and Quentin), post-Lachmannism (Giorgio Pasquali and, to a certain degree, Michele Barbi) and - why not? - neo-Lachmannism (as part of the Italian school of Romance philology).]

As Paolo Chiesa puts this: "Discovering some limits of the genealogical method and discussing them has produced greater self-awareness, and has given scholars a more mature and refined method" (2.2.8 above). Even though, as far as I know, the term "n eo - L a ch m an nis m" (It. neolachmannismo) was coined by Gianfranco Contini in the 1970s in order to refer - by and large - to his own studies and to those of his pupils (cf. the above quotation), it seems nonetheless fully legitimate to employ the adjective "neo-Lachmannian" and the noun "neo-Lachmannism" in a wider sense to refer to all those who, from the 1930s onwards, have participated in the maturation and refinement of the method of common errors. Among others, Blecua (1995) did so in a substantial review of Spanish textual criticism, and Salemans - who occupies a unique position in what might be called the Dutch school used the term in the very title of his noteworthy doctoral thesis (2000), "Building Stemmas with the Computer in a Cladistic, Neo-Lachmannian, Way: The Case of Fourteen Text Versions of Lanseloet van Denemerken".

In this larger sense, it can be argued that the refinements of Lachmannism triggered by Bédier's corrosive criticism constitute a new synthesis of theoretical positions that came into conflict in the third decade of the last century, and perhaps we can look at this as a new paradigm in a Kuhnian sense (Kuhn 1962).

\subsubsection{The diffusion of neo-Lachmannism in the twentieth century}

In central and southern Europe, methodological reflections followed almost immediately after Bédier's criticism in 1928, at least among the more attentive scholars. In order to suggest a list - albeit certainly incomplete - of the most timely and significant reactions, we may quote the studies of Rajna (1929), Pasquali (1934), Maas (1937), Barbi (1938), Fourquet (1946, 1948-1949), Castellani (1957), and Timpanaro (1961). Many of these scholars are Romance philologists, but the importance of the questions under debate did not escape classical scholars. Besides Maas, Pasquali, and Timpanaro, it will suffice to cite here the names of Kenney and Reeve (a very rich collection of Reeve's methodological papers is Reeve 2011a). Nevertheless, it seems that these discussions have remained almost unnoticed by the rest of the world. 
As the fairly recent bibliography on textual criticism by William Baker and Kenneth Womack (2000, 75-131) evidently conforms to its own "Monroe Doctrine" and ignores any work not written in English, I suggest a simple experiment to estimate the diffusion of the neo-Lachmannian turn in twentieth-century North American textual studies. Let us take the important and popular book by Greetham (1995) entitled Scholarly Editing: A Guide to Research, which dedicates twenty-four chapters to the same number of research fields (from "The Hebrew Bible" to "EighteenthCentury English Literature", and from "Russian Literature" to "Arabic Literature"), so that it may well be seen as a map of textual criticism at the end of the millennium from the American standpoint. On the basis of the invaluable "Name and Title Index" in Greetham's book, the following table (table 2.1-1) displays in chronological order the presence or absence of references to Lachmann, Maas (readable since 1958 in the English translation by Flower), the equally but differently anti-Lachmannian Bédier and Quentin, and well-known neo-Lachmannian scholars (Pasquali, Kenney, Reeve, and Timpanaro - the latter was not yet readable in the 2005 English translation by Most when Greetham's book was published, but had been translated into German by Irmer in 1971). The last column is for Tanselle, perhaps the leading American textual scholar of his generation. No references at all to these authors are found in the other twelve contributions in the collection, which are not listed here.

There is no need to emphasise both the knowledge mastered by Tanselle and his popularity among US textual scholars. On the other hand, we must note that, no differently from the Italianist Barbi or well-known neo-Lachmannian Romance scholars such as Avalle, Segre, Vàrvaro, and Contini himself, whose output is also very rich from the point of view of methodology, Kenney and Reeve are quoted mostly or exclusively within their own discipline, that is, classical Latin. Robert Huygens and Giovanni Orlandi, that is, two eminent and original textual critics in the field of mediaeval Latin, are never quoted. If we except Tanselle and Tarrant, the works of Bédier, Quentin, Maas, Pasquali, and Timpanaro are cited only by Romance scholars, and three out of four of those Romance scholars are Europeans or Latin Americans. Thus, the reader of this companion might be tempted to think that, in 1995, many North American textual scholars ignored or considered negligible not only the contribution of the Italians (for which a strong linguistic barrier may be to blame), but even that of two excellent British Latinists, Kenney and Reeve. Of course, this table might simply highlight the different relevance which the history of the discipline and discussions about methods have in North American textual criticism, but that does not substantially change its implications for methodological consciousness.

An analysis of the indexes of authors quoted in two important Dutch collections, both entitled Studies in Stemmatology (van Reenen and van Mulken 1996; van Reenen, den Hollander, and van Mulken 2004) would not yield all that different results. It is unnecessary to stress that a lack of interest in the history and methodological development of an academic discipline leads, very often, to the reinvention (sometimes in a wrong or imprecise way) of criteria and principles that have already been formulated perfectly well. 


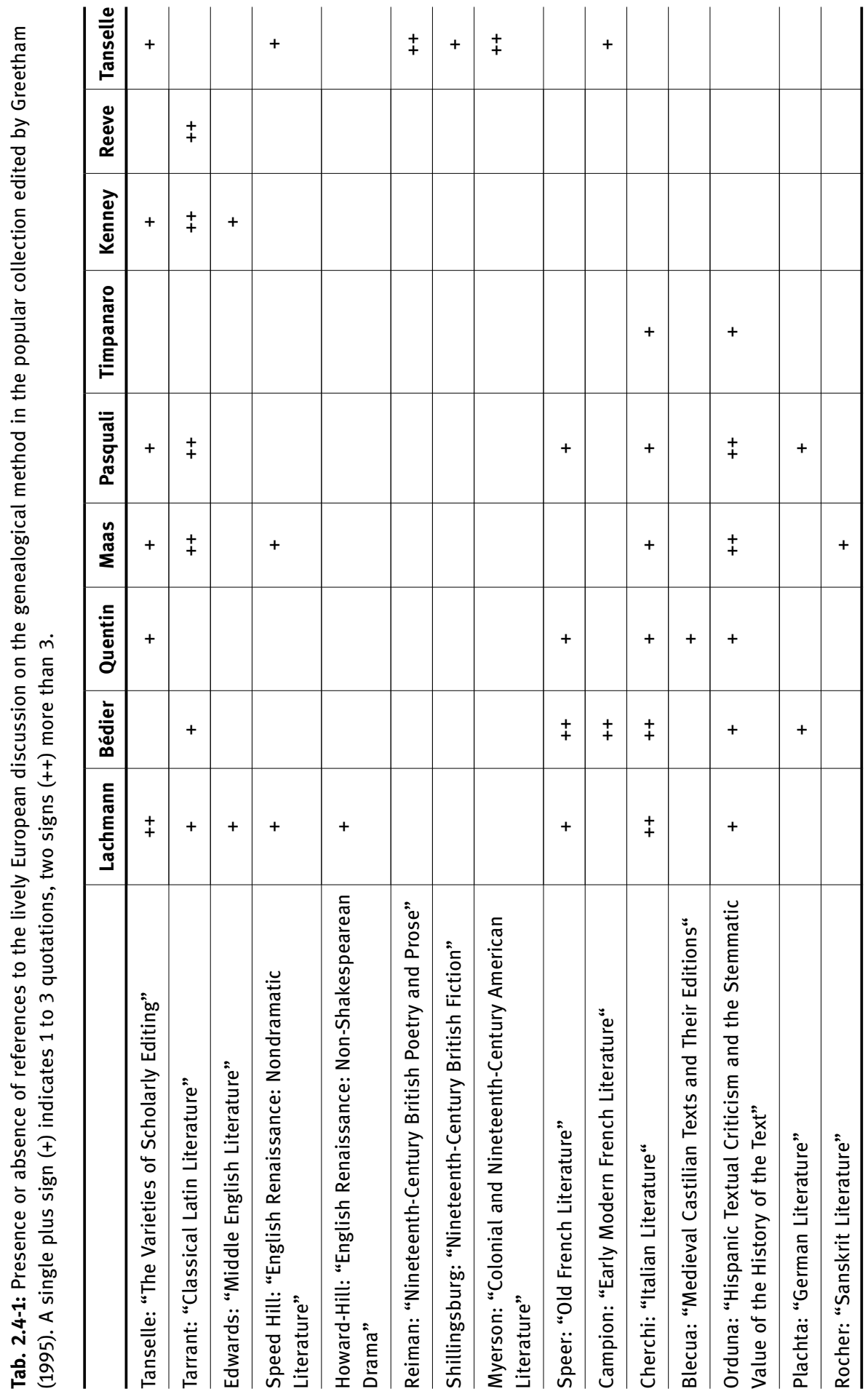




\subsubsection{Some neo-Lachmannian contributions to the improvement of the method: A provisional list}

In 2014, I proposed and commented on a small list of Bédier's contributions to the improvement of the genealogical method (Trovato 2014; see also Trovato 2017, 8294). Here, I take up that list again, updating it and opening it up to neo-Lachmannism in the broader sense. Even if a thematic arrangement might perhaps be more convenient (and certainly less dangerous for the present writer), I prefer to follow the chronological order in which these updates and refinements were proposed, and I offer only a few, essential bibliographical references (of course, since I am far from all-knowing and this is, to my knowledge, the first list of this kind, it is very likely that some achievements had been made earlier and should actually be credited to different authors). Note that I do not try to identify the first time that a specific criterion was used, but the first time that the advantage of a procedure was highlighted from a general, methodological point of view. For a more detailed and systematic treatment of the most relevant terms and notions touched on here from a diachronic perspective, see Trovato (2017) and chapter 4 below, which addresses some of them from different points of view.

Notwithstanding their different focus and size, the conceptual distance between my list from 2014 and the present one is not as great as one might think. Indeed, even when Bédier is not explicitly mentioned, the shadow of his sharp criticisms almost always seems palpable. The first group of entries mostly concerns developments which we must credit to Pasquali $(1932,1934)$ and to Maas (1937). As for the latter, it should be remembered that Maas (1937) was added afterwards as an appendix to the subsequent editions of his 1927 Textkritik (Maas 1950, 1957, 1960) and included in all the translations of it. Thus, when we use any recent edition or translation of Maas's substantial booklet, including the English translation by Barbara Flower from which I usually quote in these pages (Maas 1958), we must consider that the text was written in 1927, but Maas (1937) was added as an appendix to the treatise of 1950 and a second appendix ("Retrospect 1956") was added to the 1957 version, almost without any changes to the main text in each case. In other words, these three parts (pp. 1-41, 42-49, 50-54 in the English translation) mirror different phases and focuses in the research of this great scholar.

\section{9: Recognition of limitations of the method (Rajna)}

A few months after Bédier's famous attack against "la méthode de Lachmann", Pio Rajna (1847-1930), one of the oldest and more authoritative Italian Romance philologists, wrote the following words, which did not go unheeded: "Troppo poco si è badato alle cause perturbatrici, tali in moltissimi casi da rendere inapplicabile il sistema; e si è commesso il grave errore di procedere allo stesso modo in condizioni assai diverse" (Rajna 1929, 50) [We have paid too little attention to disturbing factors, such that could make the system inapplicable in a great number of cases, and 
we have made the serious mistake of proceeding in the same manner under very different conditions]. A few examples of cases and kinds of texts for which the method is inapplicable or requires adaptation (works transmitted by one or a few manuscripts; works that are too short, such as sonnets; popular genres such as chansons de geste or cantari, or mediaeval Latin hagiographical texts) are listed in Trovato (2017, 155-161), but we could also add encyclopedias, chronicles, collections of short, practical texts, and so on. Perhaps, among the top-notch Italian textual scholars, it was the late Alberto Vàrvaro (2004) who heeded Rajna's concerns the most.

\section{2: The method must not be used with different authorial versions (Pasquali)}

From Bédier to the present day, many scholars have warned that a flaw of neoLachmannism is the possible existence of authorial variants. But the distinction between the treatment of scribal and authorial variants has been clearly presented since at least Pasquali (1932). Of course, whenever it is possible to distinguish two or more different authorial versions, approved by the author at different times (e.g. Ariosto's Orlando Furioso of 1516, 1521, and 1532; Chateaubriand's three versions of his Atala; Whitman's many versions of Leaves of Grass), scholars are not entitled to create a "texte unique et monstrueux" (Bédier 1913, xxxviii) by antihistorically merging variants belonging to the different versions. On the contrary, we must publish them separately or decide which version is more urgently to be made available to the community of readers. In fact, in the case of multiple authorial versions, it is not a matter of deciding which reading in every place of variation best represents the work of art, but of putting up for comparison two or more textual entities which, at different times, have reflected the author's intention. This will allow critics to compare these different works and contrast their features and evolution.

After a few but very clear hints by Pasquali (1932, 1934), Contini’s seminal essay on Ariosto (1937), and the application of his "critica delle varianti" to Leopardi, Proust, and others, the treatment of authorial versions was addressed and refined by a scholar closely connected with Contini: Dante Isella. It must be emphasised that the Italian critica delle varianti is quite different from the French critique génétique (see Italia and Raboni 2010; Stussi 2015, chap. 5; 7.9 below).

\section{2-: Open vs closed recensions (Pasquali)}

Nowadays, we frequently use the expressions "closed recension" and "open recension". It is often forgotten that the author of this common distinction was none other than Giorgio Pasquali (the distinction is already found in Pasquali 1932):

Le riflessioni qui brevemente esposte [...] si applicano a ogni "recensione aperta”, se mi sia lecito introdurre qui un termine nuovo, che mi pare indispensabile, vale a dire si applicano ogniqualvolta la lezione dell'archetipo non si può fissare meccanicamente, mediante la consta- 
tazione di coincidenze di lezione in certi apografi ("recensione chiusa"), ma si determina solo con il iudicium, scegliendo sul fondamento di criteri prevalentemente interni tra due (o più) lezioni nessuna delle quali è dimostrata secondaria dal criterio esterno, genealogico. (Pasquali 1934, 126)

[The reflections briefly outlined here [...] apply to every "open recension", if I may introduce here a new term which seems to me indispensable, that is to say, they apply every time the reading of the archetype cannot be fixed mechanically through coincidences of readings in certain apographs ("closed recension") but is determined only through iudicium, choosing on the basis of predominantly internal criteria between two (or more) readings, none of which is demonstrated secondary by the external, genealogical criterion.]

Of course, the main cause of open recensions is the distribution of the variants in the stemma: if in a certain place of variation no reading appears in the majority of primary branches, we must use iudicium.

\section{4-: Extension of the field of philological studies to areas which Maas 1927 had excluded (Pasquali, Frank, and others)}

Pasquali's crucial book (1934), which should be mandatory reading for everyone interested in textual criticism, was born as a review of Maas (1927). The best abstract of the book is found perhaps in Maas's preface to the second German edition of Textkritik:

Die erste Auflage dieses Abrisses (erschienen 1927) wurde 1929 von G. Pasquali sehr eingehend und freundlich besprochen (Gnomon 5, 417 ff). Die anschließenden selbständigen Forschungen Pasqualis (Gnomon, 5, 498 ff. und Storia della tradizione e critica del testo (1934)) bewegen sich vorwiegend auf nahverwandten, aber von meiner Darstellung augeschlossenen Gebieten, dem der speziellen Überlieferungsgeschichte und dem der kontaminierten, also nicht methodisch entwirrbaren, Überlieferung. (Maas 1950, 3; my emphasis)

[The first edition of this essay (published in 1927) was reviewed with great kindness and in great detail by G. Pasquali in 1929 (in Gnomon, V. 417 ff.), Pasquali’s own investigations (in Gnomon, V, $498 \mathrm{ff}$. and in his Storia della tradizione e critica del testo, 1934) deal in the main with topics closely related to but excluded from my presentation, i.e. with the history of transmission of the individual texts and "contaminated" traditions, which of course cannot be systematically disentangled.] (trans. Flower 1958, n.p.; my emphasis)

Among other things, Pasquali also addresses authorial variants and explains with a wealth of erudition why scholars cannot dismiss recent witnesses (recentiores non deteriores).

Frank pointed out that when we work with popular genres such as mediaeval chansonniers, the conditions of the transmission are quite different from the ideal conditions in which the genealogical method can work at its best:

La tradition que constituent les chansonniers lyriques du Moyen Âge apparaît, pour qui veut établir un stemma, comme grevée de tous les éléments de trouble: [1] original multiple (réel, virtuel ou possible), [2] variations et contaminations surgies de la transmission orale, [3] conta- 
minations dues à l'utilisation par les copistes de plusieurs sources divergentes, [4] l'existence, enfin, dans les chansonniers mêmes, d'éditions résultant d'un travail réfléchi, usant de la conjecture. Que nous sommes loin de la transmission mécanique qui garantit l'efficacité du stemma! (Frank 1955, 472-473)

[The tradition constituted by the lyric chansonniers of the Middle Ages seems fraught with every sort of difficulty for the scholar who wishes to establish a stemma. (1) a multiple original (real, virtual, or possible); (2) variations and contaminations stemming from oral transmission; (3) contaminations due to the use of several divergent sources by the copyists; (4) and finally, the existence, in the chansonniers themselves, of editions resulting from thoughtful work, employing conjecture. How far we are from the mechanical transmission that guarantees the efficacy of the stemma!] (Frank 1976, 135)

In spite of this, some exemplary studies have shown that it is possible to approach the study of songbooks (chansonniers, canzonieri) in a rational way (e.g. Barbi 1915; Avalle 1985).

\section{4: Polygenetic vs monogenetic errors (Pasquali)}

In order to single out significant tools for proving the relationship between copies (i.e. for inferring stemmata), it is important to distinguish between, on the one hand, unique innovations and, on the other hand, variants that copyists could produce independently of one another. The commonly used distinction between polygenetic and monogenetic innovations goes back to Pasquali: "Corruttele comuni a tutta la tradizione [...] possono essersi prodotte indipendentemente anche in mss. indipendenti, per 'poligenesi'” (Pasquali 1934, 19) [Corruptions common to a whole tradition [...] may have occurred independently, even in independent manuscripts, by "polygenesis"]. Instead of "polygenesis", other scholars use the more opaque terms "parallelism", "coincident variation", "convergent variation", or "homoplasy”. See also the next point.

\section{7: Indicative errors and formulation of the basic rules for determining the relationship between two witnesses (Maas)}

In his paper "Leitfehler und stemmatische Typen" [Indicative Errors and Stemmatic Types], Maas (1937) introduces two fundamental distinctions. The first opposition involves indicative vs non-indicative errors, the former being useful, the latter of no use, for inferring a genealogical relationship even if errors of both types belong to the set of substantial errors (for more on significant errors, see 4.3.1 below). By the way, Maas only discusses the "logical" requirements of the indicative error, which must be "so beschaffen [...], dass aller Wahrscheinlichkeit nach B und $C$ nicht unabhängig voneinander in diesen Fehler verfallen sein können” (Maas 1950, 27) [of such a nature that it is highly improbable that B and C committed it independently of each other] (trans. Flower 1958, 43). The first requirement for an indicative error is, in Pasquali's words, that of being monogenetic (see above). Second, the error must be really difficult to detect and correct. 
The second opposition applies only to indicative errors and distinguishes between separative and conjunctive errors. The presence of a number of common errors (i.e. conjunctive errors) proves that two or more witnesses, $A B$..., are part of the same group or family, while, say, indicative errors in witness $A$ only (i.e. separative errors) show that $B$, which lacks them, cannot descend from $A$. Therefore, if two witnesses (say $A$ and $B$ ) are connected by conjunctive errors, and both of them have separative errors, they must descend from a lost exemplar y. See Maas (1937) and subsequent editions, including Maas (trans. Flower 1958, 42-44).

As I have already noted, the wording of some sentences of Maas (e.g. the ones about conjunctive and separative errors) is very similar to that of Rajna (1907). Further research will show whether Maas (who indeed read a lot, even outside his own field of study, for example about Shakespeare or Bédier's theories) depends on Rajna or they both depend on a still unknown source. But all the "sources" of Maas's treatise, whether declared or implicit, deserve a specific study (Trovato 2017, 56). Conversely, the Maasian "rules" concerning the relationship among three witnesses (Maas, trans. Flower 1958, 44-49) do not hold water (Timpanaro 1981, 128-131= 2004, 135-138 = trans. Most 2005, 162-166). See also “1937” and “2002” below.

\section{7: Eliminatio codicum descriptorum (Maas)}

After the hints in Maas (1927, § 8a), a rigorous set of logical rules for the individuation of copies of preserved copies (codices descripti), that is, genealogically useless witnesses, is found in Maas (1937, later included in Maas 1950, 1957, 1960). Between any two witnesses $A$ and $B$, only three kinds of relationship can exist - types 1,2 , and 3 in figure 2.4-1 below.
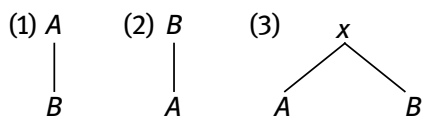

Fig. 2.4-1: The possible relationships between two witnesses $A$ and $B$, according to Maas (1937).

There are two necessary conditions for type 1 ( $B$ derives from $A$ ) that must apply: $B$ must contain all the significant errors of $A$ and at least one that is not in $A$ (obviously, a number of errors of the latter kind provide much more reliable proof than a single one). Likewise, for type 2 ( $A$ derives from $B$ ) to apply, $A$ needs to contain all the errors of $B$ plus at least one that is not in $B$. In both cases, we can distinguish between an exemplar, genealogically relevant, and a codex descriptus, genealogically of no use unless it preserves passages of the exemplar lost or destroyed after copying. See also "1958-" below.

\section{7-: First attempts to explain Bédier's so-called paradox (Maas and others)}

The strongest argument against the genealogical method, known as Bédier's paradox, is the fact that, out of 110 stemmata of French manuscript traditions 
Bédier examined, 105 were two-branched. According to Bédier, these figures were enough to prove that the method was inherently wrong. After Maas (1937) and Forquet (1946), other scholars also addressed the reasons why stemmata are so often bipartite in classical and Romance textual transmissions. Here, I mention at least Castellani (1957) and appendix C in Timpanaro (1961; appendix C is reprinted with updates in Timpanaro 1981; according to Reeve 1986, $69=2011$ a, 43, "there is no better warning against the pitfalls that may occur in classifying manuscripts"). More general and powerful explanations of the paradox were suggested later; see "1987-" below.

\section{8-: Recognition that, eventually, the method had been considerably updated and refined (Barbi)}

Before presenting his brief criticism of Quentin's and Bédier's methods, Barbi notices:

Tutti sentono che il puro metodo lachmanniano è insufficiente e in certi casi inapplicabile [...]. Che si sia da molti e per molto tempo creduto di poter risolvere, ricorrendo al metodo del Lachmann, speditamente e con sicurezza di risultati ogni problema, può essere; ma ormai quel metodo s'è sviluppato, arricchito, adattato variamente ai diversi casi, e resta fondamentale nella critica del testo; e anche l'aggiunta di altri mezzi è subordinata spesso al principio degli errori comuni. Condannarlo dunque senz’altro perché non risponde sufficientemente, o non risponde affatto, a certe particolari necessità, è privarsi di un mezzo che in qualche caso risponde benissimo anche da solo o è il solo sicuramente applicabile, e in ogni indagine dà aiuti dei quali sarebbe dannosissimo fare a meno. (Barbi 1938, xvi)

[Everyone has the impression that the pure Lachmannian method is insufficient and in some cases inapplicable [...]. It is possible that many scholars for a long time believed they were able to solve quickly and with certain results every problem simply by applying Lachmann's method; but by now that method has been developed, enriched, adapted variously to different cases, and remains fundamental to textual criticism. Even the addition of other means is often subordinated to the rationale of common errors. Therefore, to condemn it because it does not respond sufficiently, or does not fit at all certain particular needs, means to deprive ourselves of a means that in some cases responds very well even on its own, or is the only safely applicable one, and in every investigation offers aids which it would be harmful to do without.]

\section{6-: Stemma codicum vs "real tree" (Fourquet and others)}

While the stemma codicum consists only of survivors, that is, the extant witnesses, Forquet noted in 1946 that textual scholars should also consider, despite it being a merely theoretical entity, the "real" or "complete tree" (Fr. arbre réel, arbre complet), that is, "l'albero genealogico di tutti i manoscritti di un dato testo che sono realmente esistiti" (Timpanaro 1981, $129=2004,136$ ) [the genealogical tree of all the manuscripts of a given text that really existed] (trans. Most 2005, 164), lost witnesses included. For a long time even excellent scholars did not distinguish between the two notions; after Fourquet (1946) and Timpanaro (1961, appendix C), see Guidi and Trovato (2004) and Trovato (2005; 2017, 65, 81-93, 138-146). I can add 
now that, no differently from Bédier, Pasquali, and many others, Maas himself seems to confuse the real tree with the stemma codicum: "Ferner liegt es im Wesen der mittelalterlichen Überlieferung, dass bei wenig gelesenen Texten nur selten von demselben Archetypus drei Abschriften genommen wurden" (Maas 1937, 293 = 1950, 30) [It is in the very nature of the medieval tradition that in the case of little-read texts three copies were rarely taken from the same archetype] (trans. Flower 1958, 48). In reality, the fact that the stemma of a mediaeval work rarely has three or more branches does not mean that the shape of the real tree could not have had three or more branches stemming directly from the original.

\title{
1952: Recasting of the geographical criterion (Lachmann and others) as a criterion of peripheral areas (Pasquali)
}

Elaborating upon very recent developments in comparative linguistics (see 8.2) theorised by Matteo Giulio Bartoli, Pasquali formulated a criterion that can be particularly useful in the study of overabundant transmissions - see also the allusions in Pasquali (1932; 1934, 8, 160, 178 = 1952, 8, 160, 178):

\begin{abstract}
Come nella linguistica è ormai pacifico che gli stadi più antichi si conservano più a lungo in zone periferiche, e che quindi coincidenza di due zone periferiche lontane l'una dall'altra in un fonema, una forma, un vocabolo, un costrutto garantisce la loro antichità, così anche coincidenza di lezione in codici scritti in zone lontane dal centro della cultura e lontane tra loro costituisce una presunzione per la genuinità di questa lezione. Spesso di testi molto letti sia nell'antichità, sia nel Medioevo, si è formata una vulgata che, come suole la moda, progrediva da un centro verso la periferia, ma non sempre la raggiungeva. (Pasquali 1952, xvii-xviii)
\end{abstract}

[Just as in linguistics it is universally agreed today that earlier stages are preserved for a longer time in peripheral areas, and that hence the occurrence of the same phoneme, form, term, or construction in two peripheral areas distant from one another guarantees their antiquity, so the agreement of codices written in areas far removed from the cultural centre and from one another constitutes an argument for the genuineness of a reading. Often texts that were much read, both in Antiquity and in the Middle Ages, form a vulgate text which spreads, as fashions are wont to do, from the centre towards the periphery, but does not always reach it.]

\section{5-: Diffraction (Contini)}

The notion of diffraction is a refinement of the well-known criterion of lectio difficilior (see 6.2.3). It is a common experience that certain places of variation are surprisingly rich in readings. According to Contini, such richness often hinges on a particularly difficult or rare reading in the original, with which many scribes grappled and to which they reacted in different ways. The best criterion for addressing such richness is thus singling out the difficult variant that can best explain such a reaction by the copyists. This variant may still be preserved, but it may also no be longer present in the manuscript tradition. In Contini's words: “C’è una progressione dalla diffrazione in presenza, dove un testimone [...] ha serbato la voce o forma relativamente rara, a quella in assenza, dove essa è rimasta documentariamente 
stravolta" (1986, $102=2007,2: 989-890)$ [There is a progression from diffraction in praesentia, where a witness [...] has retained the relatively rare word or form, to diffraction in absentia, where this word or form has been lost in the transmission].

Nevertheless, diffraction "è sufficiente a legittimare una congettura difficilior" (Contini 1986, 102) [is sufficient to legitimate a lectio difficilior conjecture]. See also Contini $(1955,1977)$. Orduna $(1995,487)$ maintains that diffraction is "the most fertile development in the Lachmannian method since Pasquali”. Buzzoni and Burgio add that "diffraction pushes the philologist's attention to focus less on the object (the identification/reconstruction of a 'good reading') than on the internal dynamism of the tradition, which is configured as a system of structures under tension" (2014, 174). A more detailed presentation of the concept of diffraction can be found in Trovato (2017, 117-124).

\section{1-: Research on contamination (Avalle, Segre, and Froger)}

Maas's treatise warns the reader that the stemma can settle "das Abhängigkeitsverhältnis der Zeugen für jede Stelle des Textes” [the relationship of witnesses for every passage in the text] under examination only "wenn jungfräuliche Überlieferung vorliegt. Gegen die Kontamination ist kein Kraut gewachsen” (1950, 31) [if we have a virgin [i.e. uncontaminated] tradition. No specific has yet been discovered against contamination] (trans. Flower 1958, 49), that is, against copies which show shared innovations with exemplars from two or more different families. But, when a text from the past was important and thus repeatedly reproduced and widely circulating, its tradition almost invariably became contaminated. Thus, textual scholars have no choice but to address contamination. Among the works on this subject, I mention only Avalle (1961) and Segre (1961; see 4.4 below).

A useful criterion for deciding which is the main source of a contaminated witness out of two possible exemplars was suggested later by Froger:

Le moyen de résoudre l'anomalie consiste à se fonder sur la fréquence relative [des accords] des groupes incompatibles, dont l'assemblage produit une irrégularité [...]. Pour choisir entre des groupes incompatibles, on accepte celui dont la fréquence est élevée, et l'on rejette celui dont la fréquence est faible; c'est-à-dire que l'on considère comme normal celui qui est engendré par une grosse collection de variantes et apparaît souvent, regardant comme anormal celui qui, engendré par une petite collection de variantes, n'apparaît que rarement. Ce faisant, on adopte l'interprétation la plus probable [...]. Étant donné par exemple les deux fréquences 15 et 1 , on fait la somme $15+1=16$; la probabilité en faveur du groupe dont la fréquence est 15 sera $15 / 16=0,9375$, et celle du groupe dont la fréquence est un sera $1 / 16=0,0625$, soit en chiffres arrondis, $94 \%$ et $6 \%$ respectivement. (Froger 1968, 112-113)

[The way to solve this anomaly is to take as our foundation the relative frequency [of agreements] between the incompatible groups whose combination produces an irregularity [...]. To choose between incompatible groups, we accept the one whose frequency is high and reject the one whose frequency is low; that is to say, we regard as normal the one that is engendered by a large collection of variants and appears often, and regard as abnormal the one that is engendered by a small collection of variants and only appears rarely. By doing so, we are adopt- 
ing the most probable interpretation [...]. Given, for example, the two frequencies 15 and 1 , we sum them: $15+1=16$. The probability in favour of the group whose frequency is 15 will be $15 / 16=0.9375$, while that of the group whose frequency is 1 will be $1 / 16=0.0625$, that is, in round percentage figures, $94 \%$ and $6 \%$ respectively.]

Segre (1961) also introduced a useful distinction between contamination of readings and contamination of exemplars. The former "è conseguenza di una collazione eseguita sull'ascendente di un codice” (Segre 1961, $64=1998,71$ ) [is a consequence of collation [i.e. of at least one collation] performed on the ancestor of a codex]. In contrast, the latter occurs as follows:

quando un copista, o per integrare un esemplare incompleto, o perché imbattutosi in un esemplare più leggibile o autorevole, trascrive alternativamente da due esemplari, la sua copia appartiene, alternativamente, a uno solo dei gruppi di provenienza dei due esemplari. (Segre 1961, $63-64=1998,71)$

[when, in order to fill in gaps in an incomplete exemplar, or because he has chanced upon a more legible or authoritative one, a copyist alternately transcribes from two exemplars, his copy belongs, in turn, to only one of the groups that the two exemplars belong to.]

Dutch stemmatologists use the term "simultaneous contamination" for the contamination of readings and the term "s uccessive contamination" for contamination by juxtaposition of exemplars; this terminology is also used below (4.4). The problem was studied more deeply by Vàrvaro (2010). Tonello and Trovato (2011) showed that, in the case of a long and popular text such as Dante's Commedia, the replacement of one exemplar with another manuscript is a feature present in more than $15 \%$ of the manuscript transmission. A more detailed presentation of this issue is found in Trovato (2017, 128-134). It should be noted that, whenever we identify contaminated witnesses of this kind, it is convenient to use two or more slightly modified sigla in order to refer to the sections of the text that depend on different exemplars (e.g. $A^{\prime}, A^{\prime \prime}, A^{\prime \prime \prime}$ ): in this way, ambiguity and useless complications both in studying the genealogy and drawing the stemma can be avoided.

\section{1-: Application of the genealogical method to cantari and other popular genres, to theatre, and to opera librettos (De Robertis and others)}

The genealogical method can also be applied, with some adaptations, to common portions of texts belonging to popular literary genres such as cantari, chans ons de geste, and the like, which are often transmitted in versions of different length and content. As De Robertis points out:

\footnotetext{
La filologia redazionale [...] non è, per intenderci, la filologia del codex optimus; e naturalmente non prescinde dall'esperienza e dagli strumenti della più affinata tecnica ricostruttiva [sc. quella neolachmanniana]. Solo che quell'esperienza va trasferita entro una nuova realtà [...], questi strumenti hanno bisogno di essere riadattati ai nuovi oggetti e alle nuove esigenze. (De Robertis 1961, 124-125)
} 
[Redactional philology [...] is not, to put it in plain terms, the philology of the codex optimus, and of course cannot do without the experience and tools of the more sophisticated reconstructive technique [i.e. the neo-Lachmannian method]. It is just that this experience needs to be transferred into a new reality [...], and these tools need to be readapted to new objects and new needs.]

For an example, consider the analysis of the transmission of Pucci's Reina d'oriente by Bettarini Bruni and Trovato (2009), summarised in Trovato (2017, 200-207). The method can be applied, with analogous adaptations, also to theatre plays (see Tissoni Benvenuti 1986; Riccò 1996). In order to allow a thorough study of the reception of $I$ T Turco in Italia by Romani (libretto) and Rossini, the method was successfully applied also to around thirty librettos of the opera printed between 1814 and 1830 (Nicolodi and Trovato 2003).

\section{3: Extra-stemmatic (or extra-archetypal) contamination (Timpanaro)}

There are cases where conjunctive errors indicate that a witness belongs to a clearly identifiable subset of manuscripts. However, some of its readings, although they cannot be found in the other manuscripts of the subset, or in any other area of the known tradition, have to be considered authentic - even after a careful examination. As Timpanaro observes:

Vi sono lezioni giuste che nessun copista filologo medievale (in certi casi nemmeno il miglior filologo moderno) può raggiungere per congettura. Un pericolo più grave consiste nell'eventualità che un copista, per es., del ramo $\alpha$ [...] abbia risanato errori non per congettura e nemmeno attingendo a uno degli altri testimoni a noi giunti, ma collazionando un codice di un ramo o di una tradizione del tutto diversa, andato poi perduto. Casi in cui bisogna ricorrere a questa ipotesi sono citati in buon numero nel libro di Pasquali [...]. Nell'articolo in "Maia", XVII (1965), che ho già avuto occasione di citare, ho proposto (p. 397) di usare per questo fenomeno il termine di "contaminazione extrastemmatica" (cioè derivante da manoscritti che non fanno parte della tradizione a noi giunta più o meno integralmente). (Timpanaro 1981, 152-153)

[There are correct readings at which no mediaeval copyist-philologist (in certain cases not even the best modern philologist) could arrive conjecturally. A more serious danger consists in the possibility that a copyist, for example, of the $\alpha$ branch [...] might have healed errors or filled lacunas not by conjecture and not even by checking one of the other witnesses that have survived to our day, but by collating a manuscript of a completely different branch or tradition which was later lost. In his book Pasquali cites many cases in which one must have recourse to this hypothesis [...]. At Timpanaro 1965: 397 I suggested designating this phenomenon by the term extra-stemmatic contamination (that is, contamination deriving from manuscripts that do not form part of the tradition that has survived more or less completely).] (trans. Most 2005, 179)

Other scholars have alternatively suggested designating this phenomenon as ex tra-archetypal contamination. See Trovato (2017, 134-138). Figure 4.1-6 in section 4.1 provides an example of the phenomenon. 


\section{3-: Partial obscuring of a hyparchetype or the archetype (Timpanaro)}

In some cases, a thorough review of the distribution of errors in the various families shows that some copies which offer some genuine or at least good readings belong to subfamilies full of innovations. In such cases, the good readings cannot go back to the archetype through the ancestors of a family: we are facing the obscuring of a hyparchetype or the archetype. This means that these copies owe their good or genuine reading(s) to conjectural emendation or to contamination with a lost witness (see “1963” above), and that our reconstruction of the relationships between the most important branches of the stemma, as well as the textual reconstruction, could become gravely biased unless we do not collate a very rich set of loci. While correct deductions about this bias can already be found in the seminal edition of Paris (1872), a recent presentation of the problem is found in Timpanaro $(1981,143-147=2004,153-157$ = trans. Most 2005, 179-184). The problem is also analysed in Trovato (2017, 147-154).

\section{0: Active manuscript traditions vs quiescent manuscript traditions (Vàrvaro)}

In 1970, Vàrvaro published a brilliant article in which, starting from Fränkel (1964), he compared from many perspectives the practices of classical scholars and Romance philologists. Among other things, he distinguished between two different scribal attitudes, the one more respectful of the text and the other more prone to adaptations and modernisations:

Quella di opere latine e greche è in genere una tradizione libraria poco folta nel settore fra archetipo e copie umanistiche [...]; è una tradizione di ambienti limitati, di professionisti (copisti o a volte studiosi) tendenzialmente rispettosi del testo tràdito: una tradizione che chiamerei quiescente. Le tradizioni di testi romanzi sono già a prima vista assai diverse per la minima distanza che intercorre tra autografo e archetipo (se pur questo esiste) e per quella assai ridotta fra questo e i testimoni conservati [...], la posizione del copista rispetto al testo è infine assai meno rispettosa: un tipo di tradizione che chiamerei attiva. (Vàrvaro 1970, $86=2004,580$; emphasis in original)

[The manuscript tradition of Latin and Greek works is generally not very plentiful in the space between archetype and humanistic copies [...]; it is a tradition of very specific milieus, of professionals (copyists or sometimes scholars) that tend to be respectful of the written text: this is a kind of tradition that I would call quiescent. The traditions of Romance works are very different at first sight in the minimum distance between autograph and archetype (if one exists) and in the very small distance between this and the preserved witnesses [...]; the position of the copyist towards the text is, finally, much less respectful: it is a type of tradition that I would call active.]

Of course, it is obvious that, in the above contrast, "Romance works" can be substituted with "works written in vernacular languages in general”. Nevertheless, as Vàrvaro adds further on, this is simply a polarised framework that does not exclude, in different times and environments, intermediary forms of both types, even in Latin or Greek. 


\section{0-: The concept of confirmatory readings (Vàrvaro, Divizia, and others)}

Indicative errors in the Maasian sense can be very difficult to find. Thus, some editors erroneously use lists of variants, which can by no means replace errors. Nonetheless, they can be useful for confirming textual relationships. In 1970, Vàrvaro noted:

L'errore debolmente congiuntivo è intrinsecamente poligenetico, sicché in teoria sia la serie breve che quella ampia [di errori debolmente congiuntivi] potrebbero essere casuali, ma è evidente che ciò è tanto meno probabile quanto più la serie è lunga [...]. Questa labilità dell'errore, a sua volta, non è che una conseguenza dello stato "attivo" della tradizione [dei testi romanzi], che non tollera a lungo guasti senza tentare di ripararli in qualche modo, col risultato, spesso, di confondere la situazione testuale. (Vàrvaro 1970, 95 = 2004, 589-590).

[The weakly conjunctive error is intrinsically polygenetic, so that in theory both the short and the long series [of weakly conjunctive errors] could be random, but it is evident that, the longer the series, the less likely this is [...]. This unreliability of the error, in its turn, is nothing but a consequence of the "active" state of the tradition [of Romance texts], which does not tolerate flaws for long without trying to repair them somehow, often with the result of confusing the textual situation.]

As pointed out above, it would be easy to object, with Maas or Luciano Canfora, that, if we do not have indicative errors, we cannot reconstruct a sound genealogy. But the question is quite different if at least a few indicative errors do exist. Paolo Divizia remarks:

quanto più ci si allontana dai [...] punti in cui si riscontrano gli errori guida, tanto minore è la probabilità che i rapporti tra i testimoni rimangano gli stessi. Per questa ragione una serie identica di innovazioni poligenetiche di poco peso distribuite su tutta l'opera dà maggiori garanzie, nella costruzione di uno stemma codicum, rispetto a pochi errori monogenetici evidenti concentrati in una sola parte del testo. (Divizia 2009, 46-47)

[the further one moves away from the [...] places where indicative errors are found, the lower the probability that the relationships between the witnesses remain the same. For this reason, an identical series of polygenetic innovations of little weight distributed over the whole work gives greater guarantees in the construction of a stemma codicum, than a few evident monogenetic errors concentrated in a single part of the text.]

Other scholars choose to connect these useful observations even more strictly to Maasian orthodoxy, maintaining that a series of weakly conjunctive errors added to a few indicative errors allows us to confirm that the relationship between the copies is the same in any passage of the work:

Especially in areas [of the copies] that have few or no significant errors, it is best to supplement them with an adequate number of confirmatory readings as a control [...], which will serve the purpose of orienting judgment in the case of dense contamination. (Trovato 2017, 117)

See also Divizia (2011, esp. 63-71). 


\title{
1976: The concept of diasystems (Segre)
}

Segre (1976) proposed applying to textual criticism the linguistic concept of the dia system, which had been introduced by Weinreich in his classic work Languages in Contact to indicate a linguistic system which is a compromise between two systems that are in contact. As Segre underlines:

\begin{abstract}
Se è vero [...] che i concetti di variante, errore, lezione equipollente rientrano nei due insiemi complementari di lezioni conservate e lezioni innovate, l'individuazione del sistema stilistico proprio di ogni copista fornisce il filologo di un nuovo strumento di analisi. Non gli errori soltanto, infatti, permetteranno di cogliere l'affinità genetica tra due o più manoscritti, ma anche l'appartenenza di questi manoscritti a uno stesso sistema stilistico diverso da quello realizzato nell'opera [...]. Questo criterio diventa particolarmente fruttuoso se applicato a testi nei quali si incontrino, piuttosto che errori, vere e proprie rielaborazioni, come le chansons de geste. (Segre 1976, $283=1979$, 59)

[If it is true [...] that the concepts of variant, error, equally acceptable reading fall into the two complementary sets of preserved readings and innovations, the identification of the stylistic system of each copyist provides the philologist with a new analytical tool. Not only errors, in fact, will allow us to grasp the genetic affinity between two or more manuscripts, but also the belonging of these manuscripts to the same stylistic system different from that realised in the work [...]. This criterion becomes particularly fruitful if applied to texts like the chansons de geste, in which re-elaborations are encountered more frequently than errors.]
\end{abstract}

Perhaps we can recall here the lucid remark of Maas, who noted: "Den Kern fast jedes textkritischen Problems bildet eben ein stilistisches, und die Kategorien der Stilistik sind noch viel ungeklärter als die der Textkritik” (Mass 1950, 24-25) [The core of practically every problem in textual criticism is a problem of style, and the categories of stylistics are still far less settled than those of textual criticism] (trans. Flower 1958, 40-41). Nevertheless, the current growing availability of digitised texts and rich textual databases greatly facilitates stylistic analysis.

On a more general level, Paolo Divizia has kindly pointed out to me a paper by Segre (1978) which underlines, among other things, that neo-Lachmannism (though not mentioned as such) owes a lot of its refinements to key concepts of structural linguistics, such as the notions of the system and of paradigmatic and syntagmatic relations.

\section{1-: Emendatio ex fontibus (Orlandi, Brambilla Ageno, Maggioni, and Del Popolo)}

Within some fields of research (mediaeval Latin, Old French, Nordic and Germanic philology), singling out indicative errors can be quite difficult due to a high degree of loss and fragmentation in the manuscript material, and the compilatory nature and anonymity of many works, that is to say, the lack of strong authorial marks more common in some other fields. In these very fields, the Quellenforschung of our positivist grandfathers can play an important role, offering precious clues for distinguishing between preserved readings and innovations: 
Anche quando è possibile dimostrare obiettivamente, per via di varianti, che una famiglia sia migliore di un'altra, ossia contenga meno corruttele, ciò non ha pratica utilità a risolvere i problemi posti dal singolo passo in cui esse divergono. Qui possono valere soltanto i noti criteri interni; campo nel quale, quanto più dall'antichità ci si addentra nel medioevo, si ha a disposizione uno strumento di verifica che in generale il filologo classico non ha: le fonti dell'autore. Il caso più ovvio è rappresentato dalle traduzioni. In innumerevoli passi l'editore ha potuto decidere a favore dell'una o dell'altra classe di mss. della versione latina di Giuseppe Flavio [...] tenendo d'occhio l'originale greco [...]. A fortiori il criterio è valido per l'emendatio [...]. La scoperta di una fonte - specialmente di un modello d'imitazione letteraria, come ci ha insegnato in analoghi casi il Mariotti - serve proprio a correggere il testo. Cio è stato fatto da Dag Norberg per la Vita ritmica di s. Zeno, emendata appunto sulla base dell'opera prosastica di cui pare rielaborazione [...] e per talune poesie di Paolino di Aquileia, mediante il confronto con passi di poeti cristiani antichi cui il carolingio si era rifatto [...]. La ricerca delle fonti ha quindi fondamentale importanza anche per la critica testuale, e per tanti autori resta ancora in buona parte da fare. Talora, anzi, la lezione della fonte può funzionare come "terzo ramo" di uno stemma altrimenti bifido e "chiudere" una recensio per sé aperta. (Orlandi 1981, 336 = 2008, 7-8)

[Even when it is possible to demonstrate objectively, by means of readings, that one family is better than another, that is to say, contains fewer errors, this is not of practical use for solving the problems posed by a given passage in which they diverge. Only known internal criteria can apply here; this is a field in which, as one moves from Antiquity and enters the Middle Ages, one acquires a verification tool that, in general, the classical philologist does not have: the sources of the author. The most obvious case is represented by translations. In countless places, the editor was able to decide in favour of one or the other family of manuscripts of the Latin version of Josephus [...] by keeping an eye on the original Greek [...]. A fortiori the criterion is valid for emendatio [...]. The discovery of a source - especially of a model of literary imitation, as Mariotti has taught us in similar cases - serves precisely to correct the text. This has been done by Dag Norberg for the rhythmic life of St Zeno, corrected precisely on the basis of the prose work which seems to have been reworked [...], and for certain poems by Paulinus of Aquileia corrected by means of comparison with passages from ancient Christian poets whom the Carolingian poet had reworked [...]. The study of sources is therefore of fundamental importance also for textual criticism, and for many authors still remains to be done. Sometimes, the reading of the source can function also as the "third branch" of an otherwise twobranched stemma and "close" a recensio that appeared per se to be "open".]

See also Brambilla Ageno (1986), Maggioni (1994), Orlandi (1995, 4 = 2008, 100), and Del Popolo (2001). This method has been fruitfully applied to the edition of Old Norse sagas by Bullitta (2017), who systematically compared the witnesses of Niðrstigningar saga using the Latin source text underlying the work.

\section{2-: Deepening of the concept of the archetype (Weitzman, Reeve, Guidi and Trovato)}

The genealogical concept of the archetype introduced and used by Lachmann and some of his contemporaries was, and still can be, rather difficult to handle because the new technical meaning of the term (a lost manuscript on which the extant transmission depends) overlaps with the classical and humanistic meaning of the word (an "official text" checked by the author and intended to be published 
afterwards in further copies), thus causing ambiguity or misconceptions. Reeve observes: "Since the Renaissance, when scholars at work on the text of Greek and Latin authors took it [archetypus] up, the classical term [...] has been used in so many senses that no-one today can safely use it without defining it" $(1985,193=$ 2011a, 107).

Thus, even highly experienced scholars appear not to have broken completely free of the classical meaning of the term "archetype", failing to view the archetype as a manuscript whose existence is "by chance" detected by philologists within the stemma, and treating it instead as an especially authoritative exemplar or as the result of a sudden and inexplicable bottleneck in the ancient and mediaeval tradition whereby only one copy survived. To provide just one example of this line of reasoning, even the very competent Pasquali notes: "A chi ben consideri deve sembrare inverosimile che ogni volta di ciascun'opera tuttora superstite si fosse salvato nel Medioevo (occidentale e bizantino) un solo esemplare, mentre tutti gli altri erano andati a fondo con la caduta della civiltà antica” (Pasquali 1934, 15) [On careful consideration, it must appear unlikely that, each time, only one exemplar of each surviving work had been saved in the Middle Ages, whether Western or Byzantine, while all the others had perished with the fall of ancient civilisation].

The studies on two-branched stemmata and the loss of manuscripts by Weitzman (1982, 1987) and Guidi and Trovato (2004) allow us to explain the concept in a different and very simple way. As I have already pointed out,

tracing a tradition back to an archetype dating, say, from the fourth century, does not at all mean that "in antiquity" (or in the Middle Ages, or in the early modern period) a single witness of our text was preserved, or a single copy that was authoritative for one reason or another. What it means is that the witnesses available today do not allow modern philologists to trace their way any further back than a given manuscript (usually lost), often far removed from the original, and sometimes datable with fairly reasonable approximation. [...] In Latin and Greek classics, the archetype is often from the age of Charlemagne, so what has disappeared is not just the first four or five generations of witnesses, but - with very rare exceptions - the whole manuscript tradition preceding the ninth or tenth century AD. (Trovato 2017, 66)

The following diagrams from Weitzman (1982) can help to explain how a copy can become the archetype, for they depict different phases of a simulated manuscript tradition. In Weitzman's own words:

Omega represents the lost original. All manuscripts alive at the stated time are shown, without any ring, except that four codices descripti in the final population ("sons" of 61 and 95, another "son" of 95 and its own "son") are omitted. Manuscripts fully ringed are dead; many other dead manuscripts are omitted. A dotted ring indicates a dying manuscript. (Weitzman 1982, 59)

As noted above, the four diagrams in figure 2.4-2 depict four different phases of a manuscript tradition. It is easy to understand that, if today we could work with the witnesses extant in 1287, our knowledge of the archetype, that is " 13 ", would be more sound than that obtained by working with the witnesses found in the final 


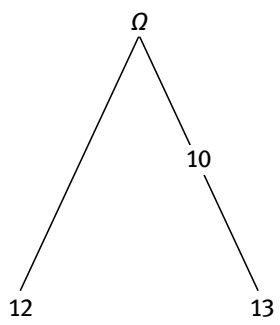

AD 941

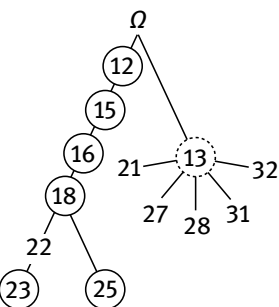

AD 1144

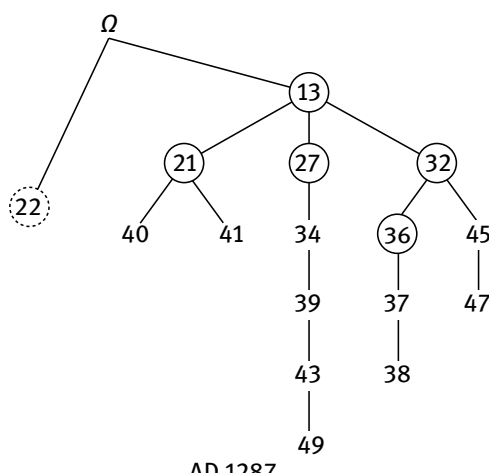

AD 1287

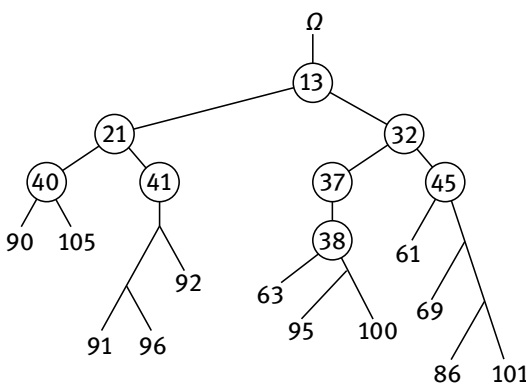

End of process

Fig. 2.4-2: Diagrams from Weitzman $(1982,59)$. The diagrams represent four phases of one of the artificial transmissions produced by means of software. I have corrected the last figure (“End of process") as per Weitzman (1987, 289).

diagram because we would still have three lines of descent from it. At the end of the process, in 1500, one of these lines is completely extinct, so we would be in trouble whenever the two surviving branches differ. What if we imagine that, both in 1287 and at the end of the process, due to a severe loss rate, only some copies that depend on "32" had survived? It is readily apparent that in this case the archetype that textual scholars could reconstruct would be " 32 " and not " 13 ". Therefore,

the archetype of the stemma has nothing to do with the history of the tradition (official copies, if any; copies commissioned for circulation by the author himself, etc.), but only with the ensemble of manuscripts that happen to be available today, used by the philologist in the stage of recensio. Textual critics should only use the word archetype to designate the point in the stemma beyond which the surviving tradition does not allow them to reach. (Trovato 2017, 66)

The concept of the archetype is further discussed in sections 4.1 and 4.2 below. In order to analyse in depth this recent process of clarification of the notion, the reader can consult Weitzman (1982), Reeve (1986), Weitzman (1987), Guidi and Trovato (2004), and Trovato (2005). 


\title{
1985-: Additional criteria for eliminatio codicum descriptorum (Timpanaro, Reeve, and others)
}

In the wake of Maas (1927, § 8a) and Pasquali (1932; 1934, 30-34), Timpanaro, Reeve, and others maintain that physical evidence is an important clue for proving that a manuscript is a codex descriptus, and not simply a relative of another witness to which it is very close but in relation to which it cannot be definitively positioned. In the words of Reeve's most important work on this topic:

\begin{abstract}
Physical evidence is any peculiarity of a witness other than its reading that accounts for an innovation in another witness. The most familiar examples are physical changes, especially damage or misbinding: a tear in a Beneventan manuscript of Apuleius accounts for gaps in many later manuscripts, and Politian demonstrated in two traditions, those of Cicero's $\mathrm{Ad}$ familiares and Valerius Flaccus, that transpositions in the majority of manuscripts had their origin in extant manuscripts where leaves were misplaced. Perhaps the most familiar example of all is a physical accretion, the speck of straw in L of Euripides that the scribe of P reproduced as punctuation before it came away in 1960 under the heat of Zuntz's lamp and the finger of a librarian [...]. A different form of physical evidence, not created by later accidents [...], is peculiarities of layout. (Reeve 1989, 10-11, $13=2011 \mathrm{a}, 152,155$ )
\end{abstract}

See also Timpanaro (1981) and Orlandi $(1995=2008,63-94)$.

\section{7-: New attempts to explain Bédier's so-called paradox (Weitzman and others)}

In the wake of Weitzman (1987; see "1982-" above), Guidi and I addressed the problem of the modifications that a real, or complete, tree (see "1946-" above) may exhibit after more or less severe loss of witnesses. We used the stemma of a relatively rich printed tradition from the sixteenth century (Sannazaro's Arcadia) as the model for a real tree (see fig. 2.4-3).

Then, we decided to decimate this model tree between $10 \%$ and $90 \%$. I quote here from my handbook the summary of the results of this experiment:

Assuming a not too slender three-branched real tree, including some thirty witnesses, and as is very often the case with the stemmata of the most diverse works - more or less markedly asymmetrical, low rates of decimation (from 10 to $30 \%$ ) do not result in very significant modifications. High decimation rates $(70,80,90 \%)$, however, result in:

a') a clear-cut increase in the probability (varying from case to case, but not inferior to $60 \%$ in the traditions Guidi and I studied) that the tree will lose some of its flimsier branches, turning into a two-branched stemma;

b') a high probability (varying from case to case) that this two-branched stemma will be drawn up from what are actually descendants of a single branch (the more luxuriant one) of a multipartite real tree.

The prevalence of two-branched stemmata thus depends on the intensity of decimation which in its turn depends on $\mathrm{T}$, that is, as I said above, the time that elapsed between the early transmission of a given text and the genealogical classification of its surviving copies. (Trovato 2017, 92) 


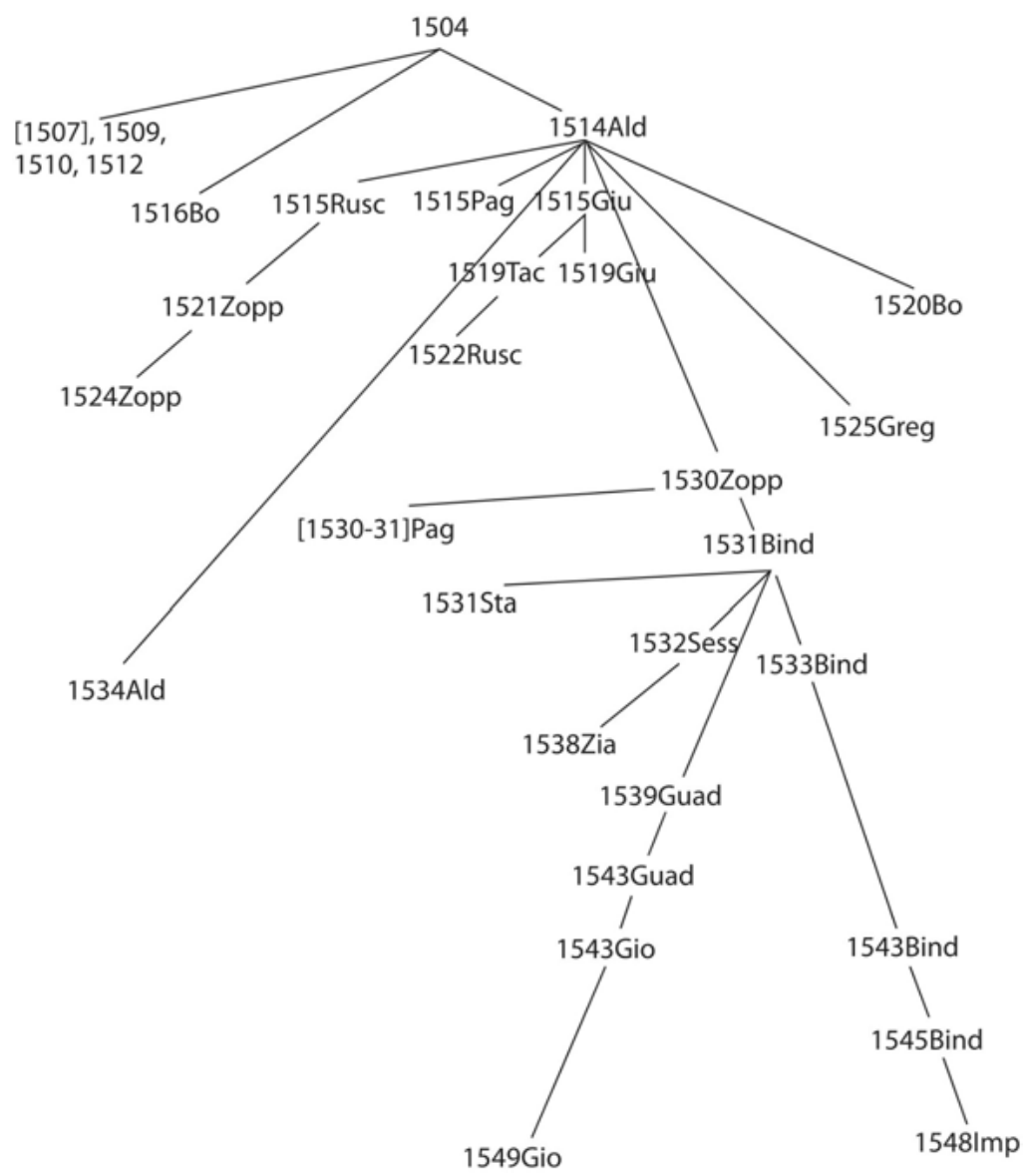

Fig. 2.4-3: The genealogical tree of a printed text (Sannazaro's Arcadia, second redaction), which is used as a model for a real tree and subjected to increasing decimation rates by Guidi and Trovato $(2004,23)$.

Several scholars (e.g. Divizia 2009, 42; L. Leonardi 2015) objected to our conclusions that a printed transmission is quite different from a manuscript tradition in many features. In my opinion, this point deserves close attention. Scientific modelling means generating a physical, conceptual, or mathematical representation of a real phenomenon that is difficult to observe directly. A theoretical model does not need to reproduce all the features of the phenomenon it intends to analyse. On the contrary: "Il problema fondamentale [nella scienza sperimentale] è stato quello di individuare per ogni fenomeno pochi dati giudicati rilevanti, decidendo di trascurare tutti gli altri” (Dalla Chiara and Toraldo di Francia 1999, 4) [The fundamental problem [in experimental science] has been to identify for each phenomenon the few data deemed relevant, deciding to neglect all the others]. For further details, I refer 
to Weitzman (1987) and Guidi and Trovato (2004), where the relationship between the loss of witnesses and the morphology of the stemma is studied in greater depth.

\section{5: Interpretatio vs iudicium: On the correct interpretation of Lachmann's "recensere sine interpretatione et possumus et debemus" and of the term iudicium (Orlandi)}

Many scholars have criticised Lachmann's "recensere sine interpretatione et possumus et debemus" (1842-1850, 1:v) [we can and must undertake recensio without interpreting], often without even having read the context of the statement. In a lucid essay, Orlandi re-evaluated a good deal of Lachmann's bequest and analysed this well-known sentence in depth. After a close reading of Lachmann's words, he remarked:

Dovrebbe essere chiaro [...] che il mantenersi al di qua dell'interpretatio non significa limitarsi a un lavoro meramente meccanico (quasi che la recensio e la conseguente constitutio textus non richiedessero scelte coscienti), bensi bandire, per quanto possibile, gli apprezzamenti personali sul pensiero dell'autore (o sulla sua poesia) per attenersi rigorosamente a ragioni oggettive: corruttele certe e indubitabili, lacune del testo, trasposizioni e così via. L'alternativa all'interpretatio è il iudicium: occorre rifuggire dalle scelte testuali fondate su preferenze individuali, e "giudicare" solo con l'ausilio dei fatti [...]. Perciò la polemica anti-lachmanniana, tante volte ripresa, a favore dell'interpretazione che tutto pervade, dipende in ultimo da un equivoco terminologico. (Orlandi 1995, $13=2008,106$ )

[It should be clear [...] that abstaining from interpretatio does not mean limiting oneself to a merely mechanical task (as if the recensio and the consequent constitutio textus did not require conscious choices), but banning, as far as possible, personal appreciation of the thought of the author (or his poetry) in order to strictly comply with objective reasons: certain and undoubted corruptions, lacunae of the text, transpositions, and so on. The alternative to interpretatio is iudicium: we must avoid textual choices based on individual preferences, and "judge" only with the help of the facts [...]. Therefore, the anti-Lachmannian controversy, claiming that interpretation is always present (so often repeated), is ultimately based on a terminological misunderstanding.]

\section{2-: Indicative errors again (Chiesa and Divizia)}

Returning to Maas's contrast between separative and conjunctive errors, Chiesa noted:

In pratica le innovazioni che effettivamente servono alla ricostruzione dello stemma sono quelle che identificano i gruppi in modo univoco. Quelle che possono essere poligenetiche non realizzano questa condizione perché la stessa innovazione può riferirsi a più di un gruppo; quelle che possono essere reversibili non la realizzano perché anche testimoni che non le riportano possono far parte del gruppo. (P. Chiesa 2002, 68)

[In practice, the innovations that are actually needed to reconstruct the stemma are those that identify the groups in a unequivocal way: those that could be polygenetic do not satisfy this condition because the same innovation may refer to more than one group; those that could be 
reversible do not satisfy it because even witnesses that do not contain them could be part of the group.]

Elaborating on the categories introduced by Chiesa, Divizia observes (the table in question is translated as table $2.4-2$ below):

I concetti di congiunzione e separazione stanno dunque su piani diversi e non contrastanti, così come le categorie di monogeneticità/poligeneticità e irreversibilità/reversibilità da cui dipendono, che possiamo rappresentare - secondo il loro combinarsi - nella seguente tabella: (Divizia 2011, 58-59)

[The concepts of conjunction and separation are therefore on different and non-contrasting levels, as are the categories of monogeneticity/polygeneticity and irreversibility/reversibility on which they depend, which we can represent - according to their combination - as displayed in the following table.]

Tab. 2.4-2: A table recording the extreme poles of a continuum of the different kinds of innovation, translated from Divizia $(2011,59)$.

\begin{tabular}{lll}
\hline & $\begin{array}{l}\text { irreversible innovations } \\
\text { ("separative errors") }\end{array}$ & reversible innovations \\
\hline $\begin{array}{l}\text { monogenetic innovations } \\
\text { (“conjunctive errors") }\end{array}$ & monogenetic irreversible (MI) & monogenetic reversible (MR) \\
\hline polygenetic innovations & polygenetic irrreversible (PI) & polygenetic reversible (PR) \\
\hline
\end{tabular}

Divizia also adds:

Da quanto si è detto, si può vedere che le opposizioni monogeneticità/poligeneticità, irreversibilità/reversibilità e evidenza/adiaforia, non sono opposizioni booleane, ma rappresentano piuttosto i poli estremi di un continuum che prevede una svariata gamma di sfumature intermedi. (Divizia 2011, 59-60; emphasis in original)

[From what has been said, we can see that the oppositions between monogenetic and polygenetic innovations, irreversible and reversible innovations, inacceptable and equally acceptable innovations are not Boolean contraries, but rather represent the extreme poles of a continuum that provides a wide range of intermediate shades.]

\section{4: On the loss rate of mediaeval traditions (Guidi and Trovato)}

"What fraction of the total number of manuscripts at one time in existence is represented by those that survive: is it $50 \%$, or $20 \%$, or less?” This quotation is from Reynolds (2000, 3). In 2004, I tried to address, at least partially, this crucial question by looking outside mediaeval manuscript traditions. I worked on the few printed books of the fifteenth and first half of the sixteenth century for which I could find the numbers of the initial prints, excepting booklets of a few folios (too thin to be easily preserved). 
Loss ranges from $73 \%$ for the parchment copies of the Decretales by Gregory IX and $76.9 \%$ for Poggio's Historia to $100 \%$ for some especially popular chivalric poems. Unsurprisingly, every edition has its own distinctive history. The only conclusion that can be drawn from these percentages is that, although the books in question were printed only a few decades before bookcollecting spread amongst the European aristocracy and high bourgeoisie [...] and although an unknown but certainly significant number of early editions are still in private collections (but this is also true of manuscripts), natural calamities (including mice and bookworms), various ways of recycling parchment and paper, fires (including those started intentionally for ideological reasons, from Savonarola to the Inquisition, the Nazis, and Serbian nationalists), plundering, bombings, and mere use seem to have done away with the majority of early European printed production in the brief space of 500 years. I do not see valid reasons to imagine that the manuscripts of classical or medieval authors, which were exposed to the same agents for even longer periods, stood higher chances of survival. On the contrary, the fact that every printed book is produced in $n$ copies, while manuscripts are unica, suggests that, with the increase of $\mathrm{T}$ [that is Time, Temporal distance], losses among handwritten texts were even more dramatic. (Trovato 2017, 108, based on Guidi and Trovato 2004, 27-29)

Loss rates are smaller in subsequent centuries. Thus:

The probability that one of the many (and converging) factors in the possible destruction of a book, whether handwritten or printed (fires, floods, war, mold, use ...), will cause its loss increases proportionally to the temporal distance (T) between us and the early copies. (Trovato 2017, 135)

As a consequence of this very high loss rate, there is a high probability that surviving mediaeval textual traditions stem solely from witnesses belonging to some vulgate tradition (see Guidi and Trovato 2004; “1987-” above).

\section{9: Multi-text codices and cluster philology (Divizia)}

The genealogical method, as is well known, does not work with very short texts (lyric poems, letters, and the like), which as a rule do not contain enough indicative errors to reconstruct a stemma. Elaborating upon studies by Barbi, De Robertis, Reeve, and others, Paolo Divizia theorised that not-obvious clusters of texts collated as a unique relatively long text could permit the determination of filiation. See Divizia (2009, 2017).

\section{9: Methods for studying scribal behaviour and scribal habits (Marchetti)}

One of the aims of the so-called New Philology is the assessment of scribal behaviour, but the studies published so far do not provide relevant information. The Colwell method, named after Ernest C. Colwell (1901-1974), proposes, once a manuscript is chosen, attributing to the copyist all its lectiones singulares without attempting to make any distinction between group and individual innovations. Elaborating upon tenets of genealogical textual criticism such as eliminatio codicum descriptorum and combining the rationales of common errors and codicological evidence (see "1937" and “1985-" above), Marchetti studied in his PhD thesis five pairs 
of an exemplar and its copy (exemplar and descriptus) of Dante's Commedia belonging to different areas, years, and graphic models. The outcome is that, while innovations in the accidental readings are around $90 \%$ of all variant readings, professional copyists, at least in fourteenth- and fifteenth-century Italy, have a dramatically low rate of significant innovations. Both if exemplar and descriptus are in a "bad" position in the genealogy (i.e. they share a number of common errors) and if they are in a prominent position (i.e. they exhibit only a few common errors), these copyists introduce new significant errors only once every eight hundred lines. There is no need to emphasise that the research of Marchetti - who is planning to verify his findings in other manuscript traditions - seems useful not only as a model for rigorously evaluating scribal behaviour but also as a diagnostic tool: whenever scholars face two or more copies which present (i) a high number of common errors and (ii) a dramatically low rate of errores singulares, they can suspect (even if codicological evidence is missing) that those copies could be in an exemplar-descriptus relation, or very close to this kind of relation.

My list, which is certainly, up to a point, personal and subjective and even partial, ends here. It can easily be enriched by readers, especially if they work in other research fields. Classical scholars will note, for example, the absence of references to the contributions of a master such as Jean Irigoin, but I preferred to work only on issues which I could master, at least to some extent. There is no need to underline that many of the additions and updates reviewed here are closely bound up with the starting assumptions of the founding fathers of the method. As Popper would put it, the theories of textual transmission on which the genealogical method was based were "passed on not as dogmas, but rather with the challenge to discuss them and improve upon them" $(1965,50)$. Therefore, they have become richer and more comprehensive. On the one hand, they are able to explain in a simple way intuitions of Lachmann's contemporaries which had not been adequately clarified (e.g. the very notion of "archetype"). On the other hand, they allow both predictions and diagnoses (e.g. that a two-branched stemma indicates, as a rule, that the witnesses suffered a high loss rate).

\subsubsection{Neo-Lachmannism in the third millennium}

As is naturally to be expected, as soon as cladistics and other forms of computerassisted philology (the greatest novelty of the end of the last century) reached a certain maturity, their promises of amazing advances and their polemical stances against the method of common errors has diminished. The latter has more and more become recognised as a method "there is no need to defend" and whose "main elements [...] are simply self-evident" (I quote from an email by Odd Einar Haugen to the authors of this chapter). Even a champion of the "new digital frontiers" of textual criticism such as Peter Robinson could declare in 2013: 
There has been a great deal of rhetoric, some of it from myself, in the last decades about how scholarly editions and editing have been fundamentally changed by the digital turn. So let me say it plainly. I don't think there has been any such change. A scholarly edition is still, as it has been for centuries, an argument about a text. The fundamental players in this argument are still documents, works, and the editor's interpretation of them. The editor is the editor, and not a "facilitator". There are still many more readers than editors, and most readers do not want to be editors. (Robinson 2013b; my emphasis)

In this different context, in a situation of greater mutual respect between philologists who favour the new methods and "traditional" textual scholars, there are signals suggesting that a renewed interest in a refined kind of genealogical textual criticism is spreading even in fields and cultural traditions that have in the past shown little interest in what happens outside the confines of their own horizons. As many of the various traditions are studied in depth in chapter 7, I restrict myself to briefly commenting on a few examples.

In France, a country where scholars traditionally follow in the wake of the Bédierist (or maybe better neo-Bédierist) tradition, the few textual critics open to the genealogical method - who were until recently confined to the Ecole des chartes and the Institut de recherche et d'histoire des textes (IRHT) - are especially productive. I mention here only the non-Bédierist manual by Bourgain and Vielliard (2002), the interesting collection edited by Frédéric Duval (2006), and the latter's lexicon Les Mots de l'édition de textes (Duval 2015).

It becomes clear even from the terminology that Alberto Blecua uses in his survey - "Wagner confused polygenetic errors and modernizations with authentic common errors" $(1995,470)$, "the ten manuscripts [...] offer not varying versions, but, rather, scribal variants that had to be organized into a stemma" (472), "the criteria of lectio difficilior and diffraction" (473), and so on - that he has been spreading a very solid and up-to-date neo-Lachmannism in Spanish-speaking countries. He did the same also in his excellent manual (Blecua 1983) and his works of textual criticism (collected in Blecua 2012).

As has been noted, Russia

did not develop its own tradition of stemmatics and the introduction of the printing press led to the search for a standard of uniformity, largely based on the ideological choices of church clerics, rather than to attention to text history. As a consequence Bédier's anti-stemmatic approach [...] was easily adopted and widely accepted during the Soviet period. (Bausi et al. 2015, 322)

Thus, and even though the Italian Angiolo Danti had tried to disseminate for many years the practices of neo-Lachmannism among Slavonic scholars (cf. the posthumously published collection Danti 1993), I consider it a very significant fact that both a partial Polish and a complete Russian translation of Maas (1960) have appeared since 1994 (trans. Sybilska 1994; trans. Toršilov 2011). For a reconsideration of Maas's fortunes as well as his importance, see now the introduction by Ziffer in Maas (2017). 
In biblical studies, which for decades were quite isolated compared to other philologies, a desire to make contact with colleagues from other fields of textual criticism that seemed unimaginable a few years ago has developed. The discovery of and the research on the Qumran manuscripts certainly brought new life to the field. For instance, there is a very popular blog on Greek New Testament textual criticism, Evangelical Textual Criticism, with more than 4,700,000 page views as of September 22, 2018 (evangelicaltextualcriticism.blogspot.com), which publishes very interesting short contributions almost on a daily basis (I mention here only the one entitled “Top Ten Essential Works in New Testament Textual Criticism”, which led to thirty-nine posts). The recent, very interesting book by Hendel (2016), called Steps to a New Edition of the Hebrew Bible, contains long quotations in English from works written in Italian by Pasquali, Contini, Segre, Chiesa, and the present writer.

In Sanskrit studies, besides Western textual scholars, there is a long tradition of Indian scholars educated abroad and knowledgeable about Western philological approaches (e.g. Sukthankar, Katre, De). In 1954, Katre published a revised edition of his Introduction to Indian Textual Criticism, in which, among other things, he offered "a glossary of some important terms used in textual criticism" and stated: "Textual criticism has come to India to stay" (quoted in Rocher 1995, 587). From the point of view of the present overview, it is worthwhile underlining, again, the interest in and comparison with European neo-Lachmannism evident in recent Indian publications (e.g. quotations from Barbi, Contini, Leonardi, Pasquali, Reeve, and Trovato in Adluri and Bagchee 2018).

A survey of Ethiopic editions can be found in Bausi 2016a (and 7.5 below). Moreover, we must remember the companion by Bausi et al. (2015), where the third chapter is dedicated to "textual criticism and text editing". This long chapter, authored by Caroline Macé et al. (pages 321-462), has a number of very detailed sections (e.g. "Textual Criticism and Oriental Languages", "Steps towards an Edition", "Heuristics of Manuscripts and Witnesses", "Witness Classification and History of the Text”, "Apparatuses”, "Philological Introduction, Translation, Commentary, Indexes and Appendices”), and offers a wealth of case studies. The chapter's introduction begins by referring to Lachmann's method, which

can be very roughly summarized as follows: complete survey of all the direct and indirect witnesses of the work to be edited (manuscripts, printed editions, quotations, allusions, translations, etc.); defining mutual relationships between the witnesses; reconstruction of an archetypal text. Since the critical edition is a scientific hypothesis, it can be disputed and new hypotheses can be proposed or new evidence can be found, which is why some mediaeval texts are edited more than once. (Bausi et al. 2015, 321)

\section{And further:}

In recent times, the opponents of the genealogical method of textual criticism and of the reconstructive method of text editing often associated with it are mustered under the flag of "new philology", a trend in scholarship which came about in the 1990s especially in the United 
States (see Gleßgen - Lebsanft 1997), following the publication of Cerquiglini (1989), claiming that mediaeval literature being by nature variable, mediaeval works should not be reduced to an edited text, but all mediaeval manuscripts should be considered equally valuable [...]. However attractive the "new philology" approach may be in the field of literary studies, it is nevertheless almost completely irrelevant for the purpose of this chapter, as it does not provide any method to edit texts with a more complex manuscript tradition. (Bausi et al. 2015, 321; my emphasis)

To come to a close, one cannot but be impressed by the distance between these formulations and the attempt by Carter to justify objectively the impossibility of applying criteria of Western textual criticism to Arabic texts:

Both filiation and copy-text present themselves as different from the corresponding topics that have attracted so much attention in Western editing [...]. Knowledge is, after all, the common property of the community, administered and distributed by people of probity and recognized competence - for this reason there is probably a much lower proportion of truly anonymous works in Arabic than one finds in medieval European literature. It is therefore unlikely that the indigenous Arabic manuscript tradition will reflect the principles and objectives of modern editing. (Carter 1995, 556-557; my emphasis)

All in all, one gets the impression that this beginning of a new millennium may herald a vaster diffusion and a more conscious application of those most conspicuous refinements of the method of common errors which, not without hesitation, we have proposed calling the neo-Lachmannian method. 